\title{
Forest
}

\section{Development Research}

\begin{tabular}{lllllll}
\hline & $R$ & $O$ & $G$ & $R$ & $A$ & $M$
\end{tabular}

\section{Manning Diversified Forest Products \\ Research Trust Fund MDFP $9 / 97$}

Biodiversity in Harvested Areas in Relation to Standing live Trees and Snags

Update 1997/98

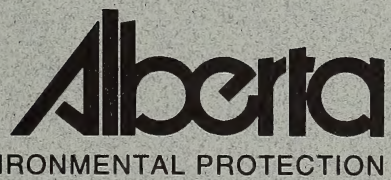




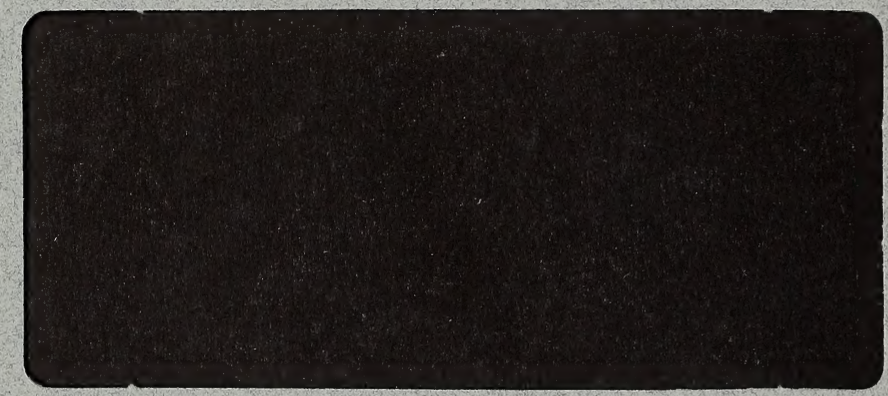




\title{
Manning Diversified Forest Products Research Trust Fund MDFP 9/97
}

Biodiversity in Harvested Areas in Relation to

Standing live Trees and Snags

Update 1997/98

\section{March 1998}

\author{
By Jim Schieck - Susan Crites - Lui Marinelli \\ Troy Sorensen and Christine Gray \\ Alberta Research Council \\ Vegreville, Alberta \\ Canada
}

Pub. No. T/417

ISBN: 07785-0238-4 
Biodiversity In Harvested Areas In Relation To The Dispersion Of Standing Live Trees And Snags: 1997/98 Year-End Report 


\title{
Biodiversity In Harvested Areas In Relation To The Dispersion Of Standing Live Trees And Snags: 1997/98 Year-End Report
}

\author{
By \\ Jim Schieck \\ Susan Crites \\ Lui Marinelli \\ Troy Sorensen \\ Christine Gray
}

1998

Vegreville, Alberta 
The study on which this report is based was funded by the Alberta Research Council, Millar Western Industries Ltd., Alberta Environmental Protection, Ainsworth Lumber Co. Ltd., Alberta Pacific Forest Industries Inc., and Manning Diversified Forest Products Research Trust Fund, which is a component of the Government of Alberta's Environmental Protection and Enhancement Fund. The views, statements and conclusions expressed and the recommendations made in this report are entirely those of the author(s) and should not be construed as the statements, conclusions, or opinions of members of the Manning Diversified Forest Products Research Trust Fund committee, the Government of Alberta, the Alberta Research Council, Millar Western Industries Ltd., Alberta Environmental Protection, Ainsworth Lumber Co. Ltd., Alberta Pacific Forest Industries Inc., or the Alberta Forest Research Advisory Council.

\section{Address Correspondence to:}

Jim Schieck

Wildlife Ecology

Alberta Research Council

Vegreville, Alberta

T9C 1T4

Phone: (403) 632-8306

Fax: (403) 632-8379

Email: jims@aec.arc.ab.ca 
We are evaluating the extent to which biodiversity in harvested areas is affected by the size and number of tree clumps that are left standing after harvest. Twelve experimental cut-blocks were created in each of two study areas. One experimental area is in pine-dominated forests near Whitecourt, Alberta, and the other is in aspen-dominated forests near Grand Prairie, Alberta. Within each of the cut-blocks in the experimental areas, $3 \%$ of the pre-harvest merchantable trees and snags were retained in clumps. One third of the experimental cut-blocks had clumps of $0.60-0.75$ ha (1.48-1.85 acres), one third had clumps of 0.14-0.15 ha (0.35-0.37 acres), and one third had clumps of 0.03-0.04 ha (0.07-0.10 acres). This research complements on-going and proposed research at the Alberta Research Council, the University of Alberta, the Network of Centers of Excellence, and forest industries throughout the Alberta by evaluating differences among dispersions of residual materials rather than evaluating differences among amounts of residual materials. All harvest patterns evaluated in this study can be implemented by forest companies that leave at least $3 \%$ of the canopy trees in some of their harvest blocks. The project started April 1997, with one year of pre-harvest biotic sampling and will continue for two years of post-harvest sampling. Although the primary focus of the project is on the biotic community, we will also evaluate the fall-down rates of trees and snags that are left standing in the experimental areas.

Within both study areas we grouped the experimental stands into four stand groups to increase the statistical power of the tests. Prior to harvest, composition and density of tree and snag species, volume of downed woody material, bird communities, and bat abundance varied among the habitat groups. However, after accounting for differences among habitat groups, forest structure and biotic communities did not vary among treatments. Thus, if we find differences after harvest they can be attributed directly to the experimental treatments. During 1998 and 1999 we will survey the forest structure and biotic communities in these experimental stands to evaluate the relative merits of leaving big versus small patches of standing trees within harvest areas.

\section{Deliverables}

As part of developing and conducting this research we have worked closely with government regulatory agencies and the forest industry to ensure that the results will be applicable to these organizations. We will continue to work with these organizations and present results (to groups and to individuals) as results become available. Specific deliverables include:

1) Progress reports submitted each year.

2) Descriptions of how the spatial pattern of standing trees and snags (i.e., variation in size and spacing of tree clumps) affects the vegetation, arthropod, bird, and bat communities within harvested areas.

3) Descriptions of the fall-down rates for trees and snags that are retained in harvested areas. Fall-down rates will be evaluated in relation to the size and placement of tree clumps in harvested areas.

4) Recommendations for clump size and clump spacing that are most suitable for meeting biodiversity goals.

5) Presentations of research findings in client reports, primary journals, and at conferences.

6) Participation in workshops, planning seminars, and committees that assess and regulate alternative harvest practices in Alberta. 
JIM SCHIECK, Project Leader and Ornithologist, Wildlife Ecology, Alberta Research Council, Vegreville, Alberta, T9C 1T4, phone (403) 632-8306, fax (403) 632-8379, Email 迆 @ aec.arc.ab.ca

SUSAN CRITES, Forest Ecologist, Wildlife Ecology, Alberta Research Council, Vegreville, Alberta, T9C 1T4, phone (403) 632-8321, fax (403) 632-8379,

Email susanc@aec.arc.ab.ca

LUI MARINELLI, Mammalogist, Wildlife Ecology, Alberta Research Council, Vegreville, Alberta, T9C 1T4, phone (403) 632-8308, fax (403) 632-8379, Email lui@aec.arc.ab.ca

TROY SORENSEN, Field Coordinator and Arthropod Ecologist, Wildlife Ecology, Alberta Research Council, Vegreville, Alberta, T9C 1T4, phone (403) 632-8305, fax (403) 632-8379, Email troy@arc.ab.ca

CHRISTINE GRAY, Technician, Wildlife Ecology, Alberta Research Council, Vegreville, Alberta, T9C 1T4, phone (403) 632-8305, fax (403) 632-8379, Email cris@aec.arc.ab.ca

Botanist, To be hired during 1999 
Alberta Research Council, Forest Resources, Vegreville, Alberta, T9C 1T4, Jack Nolan, phone (403) 632-8347, fax (403) 632-8379, Email jack@aec.arc.ab.ca Dave McNabb, phone (403) 632-8264, fax (403) 632-8379, Email dhmcnabb@aec.arc.ab.ca

Millar Western Industries Ltd., 5004 - 52 St., Whitecourt, AB, T7S 1N2.

Richard Krygier, Silviculture Manager, phone (403) 778-2221, fax (403) 778-4631, Email rkrygier@millarwestern.com

Jonathan Russell, Engineering and Planning Forester, phone (403) 778-2221, fax (403) 778-4631, Email irussell@ millarwestern.com

Alberta Environmental Protection, 4th Floor, 9945 - 108th St. Edmonton, AB, T5K 2M4

Harry Stelfox, Natural Resources Service, phone (403) 427-2044, fax (403) 422-9557, Email hstelfox@env.gov.ab.ca

Ainsworth Lumber Co. Ltd., Bag 6700, Grande Prairie, AB, T8V 6 Y9

Dave Beck, Silviculture Forester, phone (403) 831-2522, fax (403) 831-2501, Email daveb@ainsworth.ca

Grant Williamson, Divisional Forester, phone (403) 831-2515, fax (403) 831-2501, Email grantw@ainsworth.ca

\section{Manning Diversified Forest Products Research Trust Fund}

J.P. Beliech, Manning Diversified Ltd., Box 370, Manning, AB. phone (403) 836-3111, fax (403) 836-3202

N. Brownlee, Alberta Lands and Forest Service, Information Officer, Northwest Boreal Region, phone (403) 624-6221, fax (403) 624-5511, Email nwbio@env.gov.ab.ca

Alberta Pacific Forest Industries Inc., P.O. Box 8000, Boyle, AB, T0A 0M0

Shawn Wasel, Wildlife Biologist, phone (403) 525-8048, fax (403) 525-8097 
This project has required and received strong commitments from government, academia, and the forest industry.

We appreciate the strong administrative and funding support provided by the Alberta Research Council. Special thanks are extended to Jack Nolan, Dave McNabb, Gerry Lofthaug, Duane Nakonechny, Pat Soldan, Elaine Cannan, Debby Franchuk, Sonia Hunka, Nancy Fraser Hrynyk, Susan Stecyk, Patricia Ferleyko, and Kathy Ilkiw for their assistance.

We thank our technical staff for their hard work in the field with data collection. These technicians include Laura Blonski, Erika Klausz, and Jodi Tomchyshyn. We acknowledge the editing and formatting of the document by Christine Gray. Special thanks to Len Peleshok and Kelly Sturgess for helping us get the field season started.

The following people and organizations helped with logistical support in the field, equipment storage, equipment supply, and providing a knowledge base of the area. Brian Telford, Dave Beck, Grant Williamson, Andrew Allison, and Larry LeFebvre of Ainsworth Lumber Co. in Grande Prairie; Richard Krygier, Jonathan Russell, Pat Rogers, Ray Hilts, and Colin Berg of Millar Western Industries in Whitecourt; Imperial Oil, Strathcona Refinery; Alberta Land and Forest Service, Whitecourt; and the Grande Prairie Regional College. 
DISCLAIMER . i

EXECUTIVE SUMMARY ............................................................................................................................................... ii

DELIVERABLES..................................................................................................................................... ii

RESEARCH TEAM ............................................................................................................................................................. iii

FUNDING SOURCES................................................................................................................................................................. iv

GENERAL ACKNOWLEDGEMENTS .............................................................................................................................. v

TABLE OF CONTENTS ................................................................................................................................................... vi

LIST OF TABLES .......................................................................................................................................................................... viii

LIST OF FIGURES ..................................................................................................................................................................... ix

CHAPTER 1. BACKGROUND AND RATIONALE .......................................................................................... 1

Jim Schieck

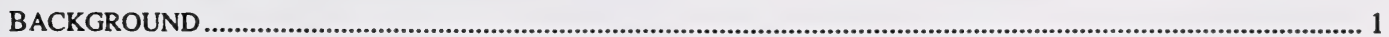

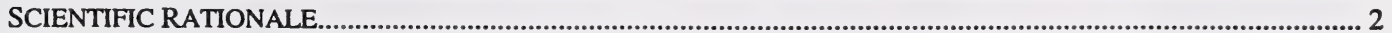

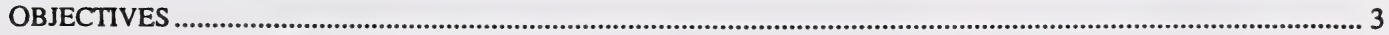

LITERATURE CITED .................................................................................................................... 3

CHAPTER 2. STUDY AREA AND METHODS .......................................................................................................... 4

Jim Schieck

GENERAL SURVEY METHODS......................................................................................................................... 7

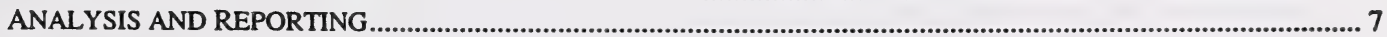

CHAPTER 3. TREES PRE-HARVEST CHARACTERISTICS AND COMPOSITION OF TREE AND SNAG COMMUNITIES IN GRANDE PRAIRIE AND WHITECOURT STUDY AREAS................................... 9

Susan Crites

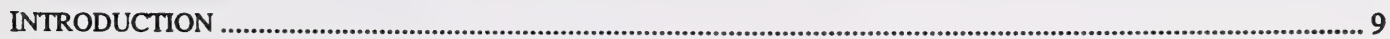

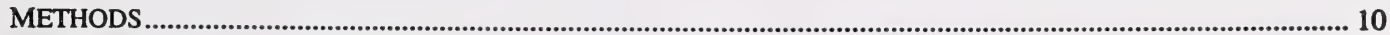

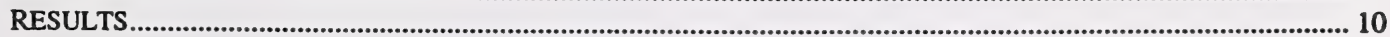

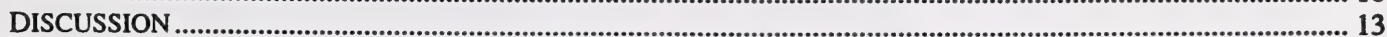

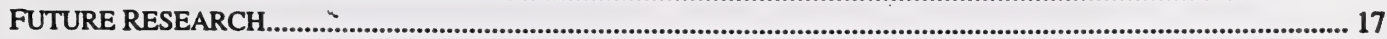

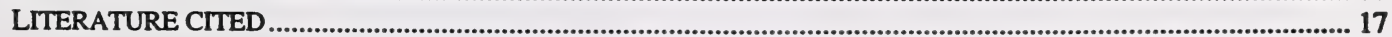

CHAPTER 4. CHARACTERISTICS OF DOWNED WOODY MATERIAL IN RELATION TO THE DISPERSION OF RESIDUAL TREES FOLLOWING HARVEST .................................................................................. 19

Troy Sorensen

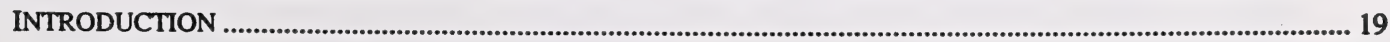

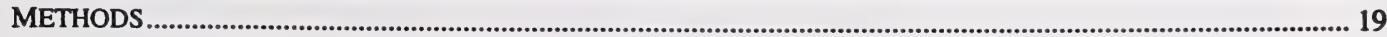

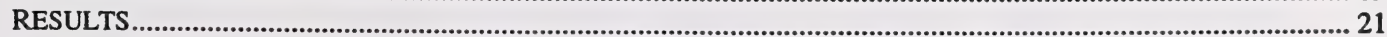

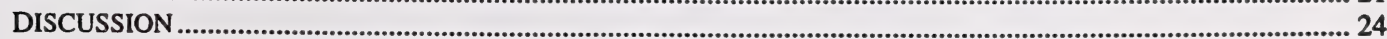

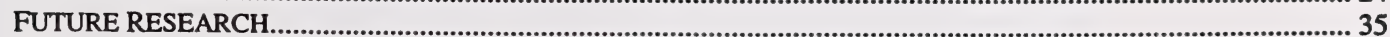

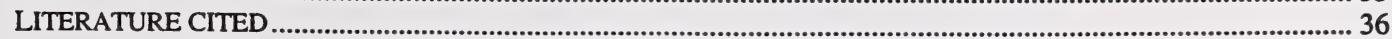


CHAPTER 5. A SUMMARY OF UNDERSTORY VEGETATION IN THE BOREAL FOREST PRIOR TO

HARVEST.

Christine Gray

INTRODUCTION

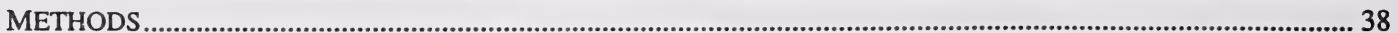

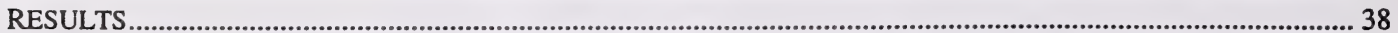

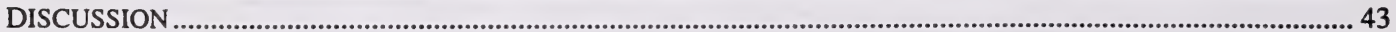

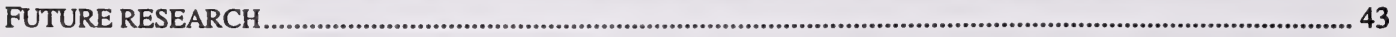

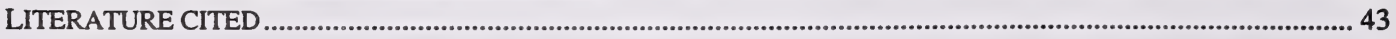

CHAPTER 6. ABUNDANCE AND SPECIES COMPOSITION OF CARABID BEETLES IN RELATION TO THE DISPERSION OF RESIDUAL TREES FOLLOWING HARVEST ...................................................... 48

Troy Sorensen

INTRODUCTION ... 48

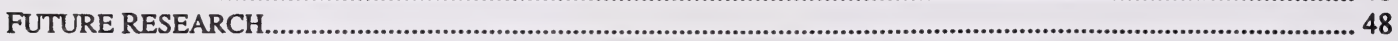

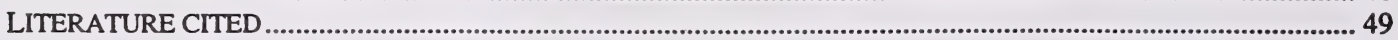

CHAPTER 7. VARIATION IN BIRD COMMUNITIES IN RELATION TO THE DISPERSION OF

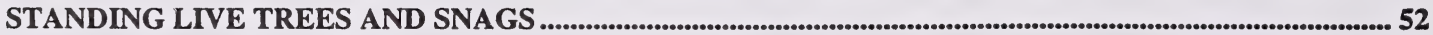

Jim Schieck

INTRODUCTION

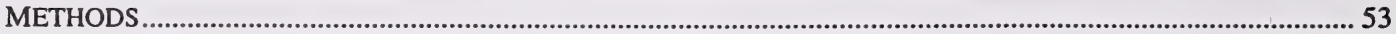

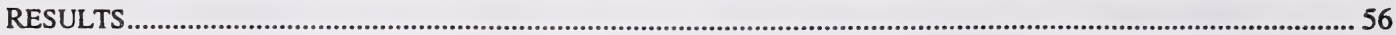

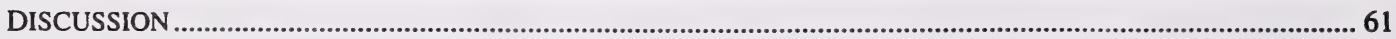

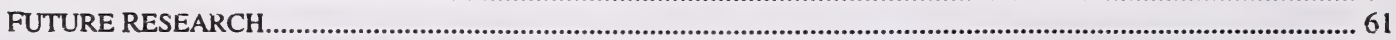

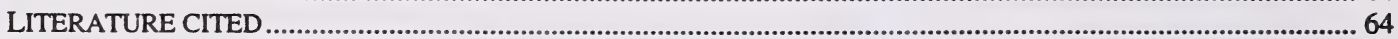

CHAPTER 8. THE USE OF RESIDUAL PATCHES BY BATS IN THE BOREAL FOREST OF

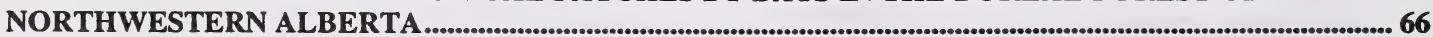

Lui Marinelli

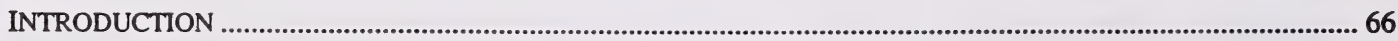

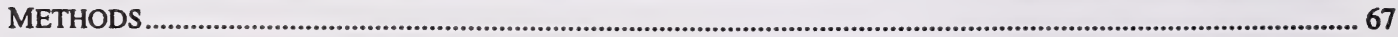

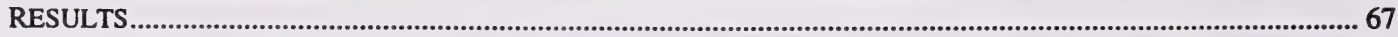

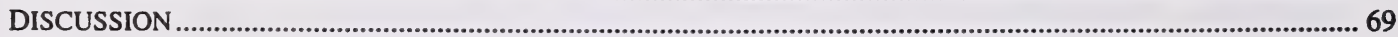

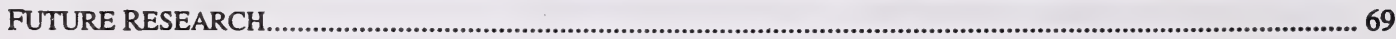

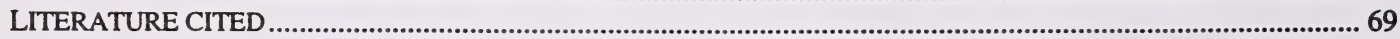


TABLE 2.1. Schedule by which forest structure and biota will be surveyed during the project.

TABLE 3.1. Percent species composition of trees and snags $\geq 1.4 \mathrm{~m} \mathrm{(} \geq 4.6 \mathrm{ft}$.) in height in Grande Prairie and Whitecourt study areas. Numbers in parentheses indicate the actual number sampled.

TABLE 3.2. Mean $( \pm S E)$ stems per hectare of canopy trees and snags $[>15 \mathrm{~cm}(>5.9 \mathrm{in}$. $)$ dbh] within each stand group and treatment for Grande Prairie study area. There were 3 and 108 degrees of freedom and 2 and 108 degrees of freedom for stand groups and treatments, respectively. Means with the same superscript letter are not significantly different. $\mathrm{Aw}=$ aspen, $\mathrm{Sw}=$ white spruce, $\mathrm{Pb}$ = balsam poplar, $\mathrm{Bw}=$ paper birch

TABLE 3.3. Mean ( \pm SE) stems per hectare of canopy trees and snags $[>10 \mathrm{~cm}(>3.9 \mathrm{in}$. $) \mathrm{dbh}$ ] within each stand group and treatment for Whitecourt study area. There were 3 and 108 degrees of freedom and 2 and 108 degrees of freedom for stand groups and treatments, respectively. Means with the same superscript letter are not significantly different. $\mathrm{Aw}=$ aspen, $\mathrm{Sw}=$ white spruce, $\mathrm{Pb}=$ balsam poplar, $\mathrm{Bw}=$ paper birch, $\mathrm{Pj}=$ jack pine, $\mathrm{Sb}=$ black spruce, $\mathrm{Fb}=$ balsam fir, $\mathrm{Con}=$ unidentified conifer species.

TABLE 4.1. Descriptions of decay classes (modified from Lee et al. 1997) assigned to large [ $>10 \mathrm{~cm}$ ( $>4$ in.) diameter] DWM.

TABLE 4.2. Average linear density of DWM $( \pm S E)$ among stand groups in both study areas. Superscripts denote homogeneous subsets as determined by Tukey's Honestly Significant Difference $(\alpha=0.05)$ for significant comparisons among groups/treatments.

TABLE 4.3. Average volume per unit area of DWM $( \pm S E)$ among stand groups in both study areas. Superscripts denote homogeneous subsets as determined by Tukey's Honestly Significant Difference $(\alpha=0.05)$.

TABLE 4.4. Average diameter of large DWM ( \pm SE) among stand groups in both study areas. Superscripts denote homogeneous subsets as determined by Tukey's Honestly Significant Difference $(\alpha=0.05)$.

TABLE 5.1. Mean percent cover $( \pm S E)$ of understory vegetation for the Grande Prairie study area during 1997. Individual species are grouped by strata level and family.

TABLE 5.2. Mean percent cover ( \pm SE) of understory vegetation for the Whitecourt study area during 1997. Individual species are grouped by strata level and family.

TABLE 7.1. Abundance (mean $\pm S E$ ), migration habits, and nesting/foraging habits of bird species that were detected in the pre-harvest forest in the Whitecourt study area and Grande Prairie study area during 1997.

TABLE 7.2. Mean ( $\pm S E$ ) species richness within sites within each stand group and treatment. Species were categorized by whether or not they used large trees or snags and their migration habitats. There were 3 and 121. degrees of freedom for the tests involving stand groups and 2 and 119 degrees of freedom for the tests involving treatments. Groups with different superscripts are statistically different (Student-Neuman-Keuls range test).

TABLE 7.3. Mean ( \pm SE) abundance per ha within each stand group and treatment. Species were categorized by whether or not they used large trees or snags and their migration habitats. There were 3 and 121 degrees of freedom for the tests involving stand groups and 2 and 119 degrees of freedom for the tests involving treatments. Groups with different superscripts are statistically different (Student-Neuman-Keuls range test).

TABLE 8.1. Mean ( $\pm S E$ ) number of little brown bat calls detected within each stand group and treatment in Whitecourt and Grande Prairie study areas. 
FIGURE 2.1. Locations of sites and stands in the Whitecourt study area................................................5

FIGURE 2.2. Locations of sites and stands in the Grande Prairie study area............................................. 6

FIGURE 2.3. An example of the transect and nested-plot layout for a 1-ha (2.47 acre) site..................... 8

FIGURE 3.1. Frequency of live trees categorized by diameter and height classes for Grande Prairie.... 12

FIGURE 3.2. Frequency of live trees categorized by diameter and height classes for Whitecourt. ......... 12

FIGURE 3.3. Frequency of snags categorized by diameter class and decay stage for Grande Prairie.

Decay stage one refers to a recently dead tree; decay stage six refers to a well-decayed snag that is soft in places with a broken bole.

FIGURE 3.4. Frequency of snags categorized by diameter class and decay stage for Whitecourt. Decay stage one refers to a recently dead tree; decay stage six refers to a well-decayed snag that is soft in places with a broken bole.

FIGURE 4.1. Size class distribution of the density (histogram) and volume (line) of DWM in the Grande Prairie study area.

FIGURE 4.2. Average linear density of DWM in each decay class in the Grande Prairie study area distinguishing between DWM raised off the ground and DWM lying on the ground.

FIGURE 4.3. Average linear density ( \pm SE) of large DWM in different decay stages among stand groups in the Grande Prairie study area.

FIGURE 4.4. Average linear density ( \pm SE) of large DWM in different decay stages among stand treatments in the Grande Prairie study area.

FIGURE 4.5. Size class distribution of the density (histogram) and volume (line) of DWM in the Whitecourt study area.

FIGURE 4.6. Decay class distribution of the density of DWM in the Whitecourt study area distinguishing between DWM raised off the ground and DWM lying on the ground.

FIGURE 4.7. Average linear density ( \pm SE) of large DWM in different decay stages among stand groups in the Whitecourt study area.

FIGURE 4.8. Average linear density $( \pm S E)$ of large DWM in different decay classes among stand treatments in the Whitecourt study area.

Figure 6.1. Locations of pitfall traps for the three patch sizes in the Whitecourt Area. Trapping design is similar for the Grande Prairie study area with the following distances from patch edges: $-50 \mathrm{~m},-20$ $\mathrm{m},-10 \mathrm{~m}, 0 \mathrm{~m}, 20 \mathrm{~m}, 50 \mathrm{~m}, 120 \mathrm{~m}$, and $250 \mathrm{~m}$ (- 55 yd., -22 yd., - 11 yd., 0 yd., 22 yd., 55 yd., 131 yd., and $273 \mathrm{yd}$.). Traps must be at least $20 \mathrm{~m}$ ( $22 \mathrm{yd}$.) apart to insure statistical independence. Traps will be placed along transects in unharvested forest with the same spacing as the traps in large patches.

FIGURE 7.1. Correspondence analyses based on bird densities in the Whitecourt study area during 1997. Sites that are close together within the correspondence plot have similar bird communities and sites that are far apart have dissimilar bird communities. Sites were categorized based on stand group. For each stand group bivariate ellipses that enclose $90 \%$ of the sites were presented (Systat Inc. 1989).

FIGURE 7.2. Predicted location for each bird species based on the correspondence analyses of bird densities in the Whitecourt study area during 1997. Species that are close together have strong positive covariance in abundance among sites whereas species that are far apart have strong negative covariance in abundance among sites. Species were categorized based on their migration and nesting/foraging habits.

FIGURE 7.3. Correspondence analyses based on bird densities in the Grand Prairie study area during 1997. Sites that are close together within the correspondence plot have similar bird communities and sites that are far apart have dis-similar bird communities. Sites were categorized based on stand group. For each stand group bivariate ellipses that enclosed $90 \%$ of the sites were presented. ........ 62

FIGURE 7.4. Predicted location for each bird species based on the correspondence analyses of bird densities in the Grande Prairie study area during 1997. Species that are close together have strong 
positive covariance in abundance among sites whereas species that are far apart have strong negative covariance in abundance among sites. Species were categorized based on their migration and nesting/foraging habits.

FIGURE 8.1. Canonical correlation analyses based on abundance of little brown bats in boreal forest stands near Grande Prairie, AB during 1997. The first correlation function describes an increasing density of aspen trees. The symbols represent each stand identified by stand group (A-D) and treatment (1-3).

FIGURE 8.2. Canonical correlation analyses based on abundance of little brown bats in boreal forest stands near Whitecourt, $\mathrm{AB}$ during 1997. The first correlation function describes an increasing density of snags with a DBH of $>20 \mathrm{~cm}$ ( $>7.9 \mathrm{in}$.). The symbols represent each stand identified by stand group (A-D) and treatment (1-3). 


\section{Jim Schieck}

\section{Background}

As a consequence of having a thriving forest industry in Alberta, much of Alberta's boreal forest has been allocated to be harvested either for dimensional lumber or for pulp and paper. The economic benefits of this intensive forest harvesting are viewed positively by Alberta's population. The ecological ramifications of extensive forest harvest, however, are poorly understood and this lack of knowledge hampers management decisions and land use planning. Consequently, the forest industry and government organizations in Alberta have been conducting research to develop forest practices that are ecologically sound, economically feasible, and sustainable.

Short rotation practices will truncate forest succession over much of the landscape and, in some areas, may result in old forests becoming relatively scarce. In addition, the removal of most of the merchantable trees from harvested areas will alter natural floral and faunal communities in those areas and may affect biotic recovery. Finally, large live trees and snags provide suitable micro-habitats for many plants, and nesting and foraging habitats for many animals, but with conventional harvest practices, few large trees and snags will be present in harvested landscapes.

Management strategies are being developed to produce harvest patterns that are as similar as possible to natural disturbances. Since large trees and snags are abundant following natural disturbances, but are greatly reduced in harvested areas, forest managers have been recommending that as much standing residual material as is socially and economically feasible be retained within harvested areas. Clumps of standing trees and snags in harvested areas may function similar to skips in wildfire areas, and thus act as refugia for some species while the harvested forest re-grows. If residual standing live trees continue to grow, they will become large live trees and may produce some large snags in mid- and late-rotation forests. These large live trees and snags may provide some of the structures and micro-habitats that are normally found only in post-rotation aged forests.

Given the complexity of natural ecosystems, it is not surprising that the ecological and biodiversity impacts of these alternative harvest/silviculture practices are poorly understood. Only by experimenting with new techniques in the field, and monitoring the resulting ecosystems throughout a harvest rotation, will we begin to understand the potential impacts and benefits of each technique. To this end, research has been conducted by scientists within the Alberta Environmental Protection, the University of Alberta, the Network of Centers of Excellence, and forest industries throughout Alberta's boreal forests. Preliminary results from past and ongoing stand-level research indicates that biodiversity in harvested areas is positively related to the amount of standing trees and snags retained in those areas. However, only anecdotal information is available to evaluate whether the dispersion of those standing residual trees also affects the ecology and biodiversity in harvested areas. The present study will fill that gap in our knowledge by evaluating whether the biota present in harvested areas with small clumps of trees differs from that present in harvested areas with large clumps of trees. If clump size has a direct impact on biota, then by leaving trees and snags in the appropriate clump sizes, forest managers may obtain benefits to biodiversity at little additional cost. The proposed experimental treatments will be monitored throughout a harvest rotation (extended monitoring is not part of the present proposal) to enable researchers to evaluate changes in trees, understory vegetation and wildlife over time. This controlled experimental study will contribute to the adaptive management of boreal forests and will provide information that forest managers can use when designing harvest plans. 


\section{Scientific Rationale}

All else being equal, it would be beneficial to make harvest areas as similar as possible to natural disturbances since native biota evolved in an ecosystem with natural disturbances (Urban et al. 1987). The dominant natural disturbance in the boreal forests of North America is wildfires (Eberhart and Woodard 1987, Hunter 1993), and cut-block size and shape can be patterned after wildfires. There are limitations, however, to matching the amount of wood remaining in post-harvest areas with that remaining post-wildfire because only a small percentage of the wood is combusted during a wildfire but most of the wood is removed during harvest (Lee et al. 1997). Given this discrepancy, it is necessary to manage the relatively few trees and snags that are retained in harvest areas to achieve the greatest benefit for biota. Following wildfires, there are groups of unburned trees and snags (fire skips) embedded within the burned areas (Eberhart and Woodard 1987). These fire skips could be emulated in harvest scenarios by leaving clumps of live trees and snags within cut-blocks. Both fire skips in burned areas, and residual clumps of trees in harvest areas, probably retain some of the structures and micro-habitats that were present in the forest prior to disturbance and consequently, may act as refugia for some native species. Small clumps may be sufficient for a few species, but larger clumps probably act as refugia for more species (Saunders et al. 1991). For example, some animals require large undisturbed areas for protection and foraging (Porneluzi et al. 1993), and some plant species require large undisturbed areas which create suitable micro-habitats (Brothers and Spingarn 1992).

The refugia potential of residual clumps of trees is probably most important during the first few decades following harvest because many boreal forest species live at low densities in young forests (Schieck et al. 1995, Kirk et al. 1996). Thus, biota that are present in the residual clumps may disperse from these into harvest areas once the new cohort of trees is 20 to 50 years old. Distance between clumps and species dispersal abilities will affect the rate and dynamics of biotic recolonization in harvested areas (Saunders et al. 1991, deMaynadier and Hunter 1995). The degree to which tree clumps act as refugia in harvested areas, and the appropriate dispersion of those clumps to enhance dispersal of biota, have not been evaluated in boreal forests.

In addition to the refugia potential of tree clumps, there may be management value to retaining small clumps or single live trees scattered throughout harvest areas. In areas where intensive forest harvest will decrease the amount of old forest in the landscape, it may be beneficial to produce old-forest structures and micro-habitats in mid seral stages of forests (Spies et al. 1991). Many of these old-forest structures and micro-habitats are associated with large live and dead trees (Hansen et al. 1991, Schieck et al. 1995). Consequently, if some merchantable trees are retained as standing live trees at harvest, and do not get blown down, they will become large by mid-rotation and may accelerate biotic recovery in the areas. With this management strategy, single trees or many small clumps of trees, scattered over the harvest area, may have greater impact on biota than if all standing trees and snags had been retained in few large clumps because old-forest structures and micro-habitats would then be dispersed throughout the harvest area.

The most appropriate placement of standing trees and snags differs between "managing for refugia" and "managing for the production of dispersed large trees". Both patterns may be useful, but only by experimentally manipulating size of clumps and distance between clumps and then studying the biota throughout a rotation will we understand the biological and management implications of each. In this study, we established three treatments with different clump sizes and distances between clumps in two experimentally harvested areas to evaluate whether biota differ among the treatments. In the present study we will evaluate differences that are present immediately following harvest. The experimental areas will be maintained for the rest of the harvest rotation however, and proposals to evaluate differences among treatments will be submitted at the appropriate times (i.e., once the new cohorts of trees are 
well established, at mid-rotation, and just prior to the subsequent harvest).

\section{Objectives}

In the present study, we will evaluate how clump size and distance between clumps of residual live trees and snags affects biodiversity in harvested areas. All treatment areas will be sampled before and after the experimental harvest. In this report we compared pre-harvest biotic communities among treatments to ensure that treatments were similar prior to harvest.

Post-harvest biotic communities will be surveyed during 1998 and 1999 and compared among treatments to evaluate whether the biotic communities present within the first two years post-harvest are related to clump size and distance between clumps. Our results will be compared to that found in benchmark communities and to areas where other harvest prescriptions have been used.

We will evaluate: (1) whether the bird community that has specialized foraging and nesting requirements for dead trees varies among the three silviculture treatments, (2) whether the resident bird community varies among treatments, (3) whether the neotropical migrant bird community varies among treatments, (4) whether the bat community varies among treatments, (5) whether the arthropod community varies among treatments, (6) whether herb and shrub communities vary among treatments, and (7) whether fall-down rates of standing trees and snags vary among treatments.

\section{Literature cited}

Brothers, T.S., and Spingarn, A. 1992. Forest fragmentation and alien plant invasion of central Indiana old-growth forest.

Conservation Biology 6: 91-100.

deMaynadier, P.G., and Hunter, M.L. 1995. The relationship between forest management and amphibian ecology: a review of the North American literature. Environmental Review 3: 230-261.

Eberhart, K.E., and Woodard, P.M. 1987. Distribution of residual vegetation associated with large fires in Alberta. Canadian Journal of Forest Research 17: 1207-1212.

Hansen, A.J., Spies, T.A., Swanson, F.J., and Ohmann, J.L. 1991. Conserving biodiversity in managed forests. BioScience 41: 382-392.

Hunter, M.L. 1993. Natural fire regimes as spatial models for managing boreal forests. Biological Conservation 65: 115-120.

Kirk, D.A., Diamond, A.W., Hobson, K.A., and Smith, A.R. 1996. Breeding bird communities of the western and northern Canadian boreal forest: relationship to forest type. Canadian Journal of Zoology 74: 1749-1770.

Lee, P.C., Crites, S., Nietfeld, M., Van Nguyen, H., and Stelfox, J.B. 1997. Characteristics and origins of deadwood material in aspendominated boreal forests. Ecological Applications 7:691-701.

Porneluzi, P., Bednarz, J.C., Goodrich, L.J., Zawada, N., and Hoover, J. 1993.

Reproductive performance of territorial ovenbirds occupying forest fragments and a contiguous forest in Pennsylvania. Conservation Biology 7: 618-622.

Saunders, D.A., Hobbs, R.J., and Margules, C.R. 1991. Biological consequences of ecosystem fragmentation: a review. Conservation Biology 5: 18-32.

Schieck, J., Nietfeld, M., and Stelfox, J.B. 1995. Differences in bird species richness and abundance among three successional stages of aspen dominated boreal forests. Canadian Journal of Zoology 73: 1417-1431.

Spies, T.A., Tappeiner, J., Pojar, J., and Coates, D. 1991. Trends in ecosystem management at the stand level. In Transactions of the fiftysixth North American wildlife natural resources conference. Edited by R.E. McCabe, Wildlife Management Institute, Washington DC. pp. 628-639.

Urban, D.L., O'Neill, R.V., and Shugart, H.H. 1987. A hierarchical perspective can help scientists understand spatial patterns. Landscape Ecology 37: 119-127. 


\section{CHAPTER 2. STUDY AREA AND METHODS}

\section{Jim Schieck}

The study is being conducted in two forest types in the boreal forest of western Alberta. The study area southwest of Whitecourt, $\mathrm{AB}\left(54^{\circ} 10^{\prime}\right.$ $\mathrm{N}, 116^{\circ} 20^{\circ} \mathrm{W}$ ) is dominated by jack pine and black spruce that is approximately 110 years old and has between 2,000 and 2,200 canopy trees per ha (810-890 canopy trees per acre).

Throughout the area there is localized topographical relief resulting in pockets $(<5 \%$ of the total area) of aspen and white birch. Twelve stands that range in size from 27 to 46 ha, mean 34 ha (67 to 114 acres, mean 84 acres) were established in the study area (Fig. 2.1). These stands were categorized into four groups of three, based primarily on the type of vegetation that surrounded them and secondarily on the tree species composition in the area prior to harvest. Within each stand group one stand was randomly assigned to each of the three treatments (Fig. 2.1).

Stands were harvested between September 1997 and February 1998. Three percent of the preharvest volume was left in tree clumps and as many of the non-merchantable trees and snags as was possible were retained. Clumps were not placed on roads or on cut-lines, but otherwise they were dispersed in a regular pattern. To reduce wind-throw, clumps were circular and all trees within $3 \mathrm{~m}$ (10 ft.) of the perimeter of each clump were topped at 4-5 m (13-16 ft.) to create stubs. We have assumed that each stub contains one third of the volume of the original tree and have added sufficient area to each clump to replace the volume that was removed from the stubs. The number of clumps in a stand was determined based on the treatment being created and the size of the stand. Based on a stand area of 30 ha (74 acres), treatment one would have two large clumps with a diameter of $79.6 \mathrm{~m}$ (87.0 yd.) and each clump would contain 850 935 residual trees and $145-160$ stubs, treatment two would have eight medium sized clumps with a diameter of $41.7 \mathrm{~m}$ (45.6 yd.) and each clump would contain 200-220 residual trees and $75-80$ stubs, and treatment three would have 32 small clumps with a diameter of $22.7 \mathrm{~m}$ (24.8 yd.) and each clump would contain 45-50 residual trees and 35-40 stubs. During the summer of 1998 the harvested areas within the stands will be re-planted with 2-year old pine seedlings. During September 1999, the stands will be sprayed with herbicide.

The study area southwest of Grand Prairie, AB $\left(54^{\circ} 50^{\prime} \mathrm{N}, 119^{\circ} 20^{\prime} \mathrm{W}\right)$ is dominated by aspen trees that originated after a fire approximately 100 years ago. This study area has a few small depressions creating pockets of white spruce, balsam poplar, white birch, willow and black spruce. Within this study area there are approximately 800-1,000 canopy trees per ha (324-405 canopy trees per acre). The experimental design is similar to that for the Whitecourt study area. Twelve experimental stands were created by harvesting blocks in a checker-board pattern such that approximately half of the study area was harvested and half of the area unharvested (Fig. 2.2).

Stands range in size from 35 to 66 ha, mean 52 ha ( 86 to 163 acres, mean 128 acres). These stands were categorized into four groups of three, based primarily on the type of vegetation that surrounded them and secondarily on the tree species composition in the area prior to harvest. Within each group, one stand was randomly assigned to each of the three treatments (Fig. 2.2). Stands were harvested between September 1997 and February 1998. Three percent of the pre-harvest volume was left in tree clumps and as many of the nonmerchantable trees and snags as was possible were retained in each stand. Clumps were not placed on roads or cut-lines, but otherwise were dispersed in a regular pattern throughout the stand. The number of clumps in a stand was determined based on the treatment being created and the size of the stand. Based on a treatment area of 50 ha (124 acres), treatment one would have two large clumps with a diameter of $97.7 \mathrm{~m}$ (107.0 yd.) and each clump would contain 600 - 750 residual trees, treatment two would have ten medium sized 


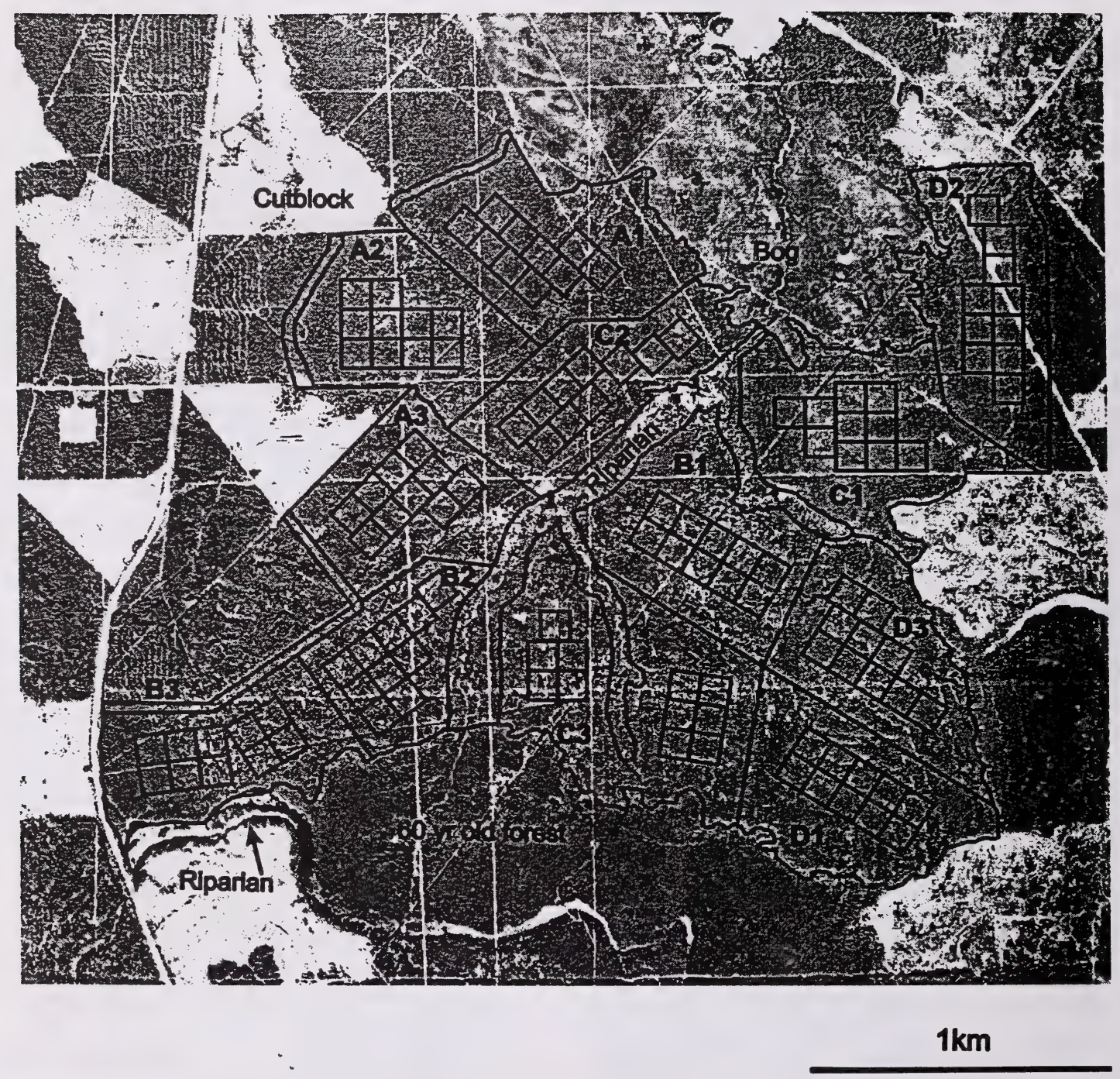

FIGURE 2.1. Locations of sites and stands in the Whitecourt study area. 


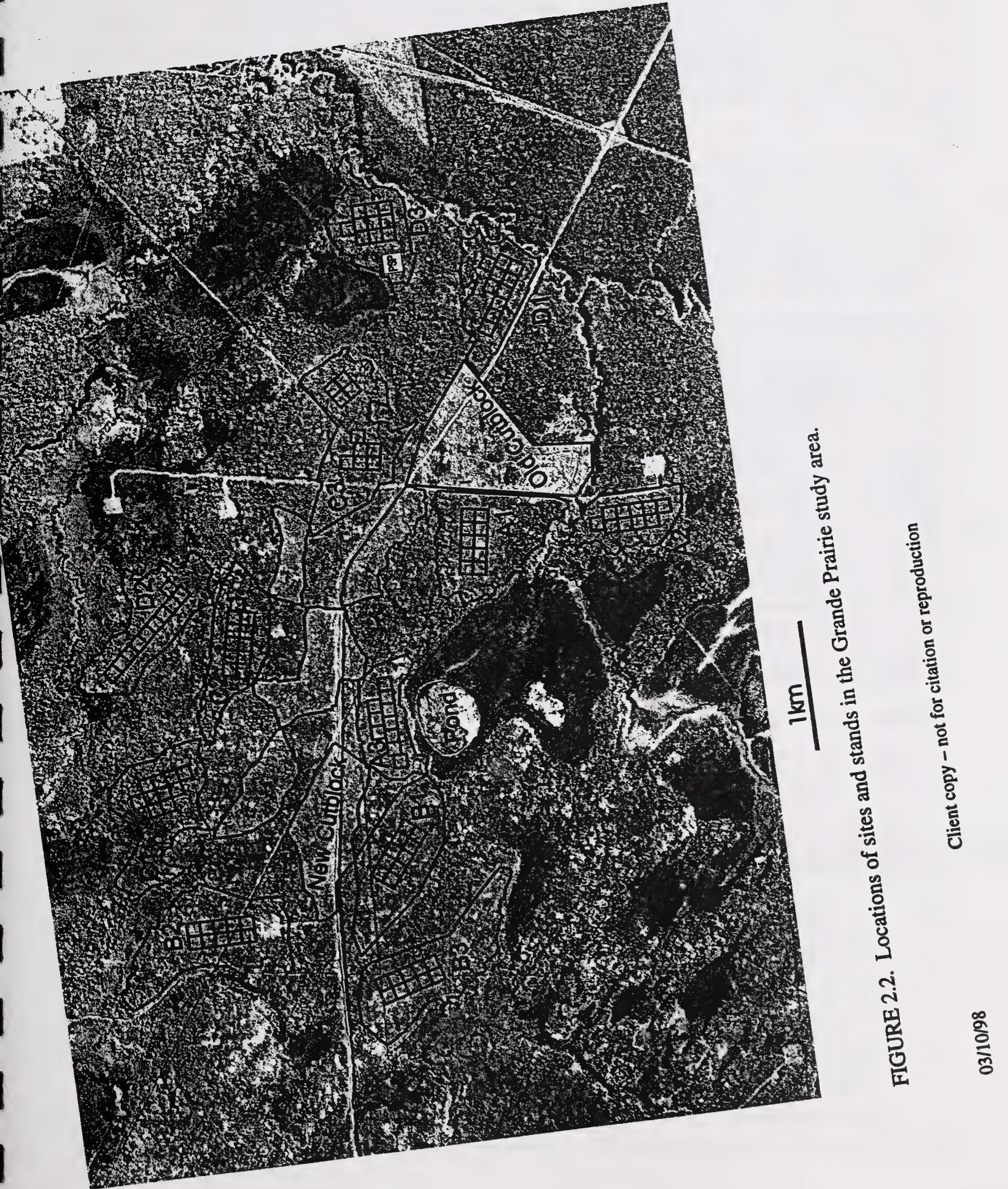


clumps with a diameter of $43.7 \mathrm{~m}$ (47.8 yd.) and each clump would contain 120 - 150 residual trees, and treatment three would have 50 small clumps with a diameter of $19.5 \mathrm{~m}$ (21.3 yd.) and each clump would contain 24 - 30 residual trees. No post-harvest silviculture is planned for the stands.

To ensure that harvest patterns were consistent among treatments, the boundaries of the clumps of trees and snags that were retained at harvest were marked with colored plastic ribbon prior to harvest. No machine activity occurred within the residual clumps of trees during harvest.

\section{General Survey Methods}

Pre-harvest surveys of biota were conducted during the spring and summer of 1997. Ten 1-ha ( 2.47 acre) sites were established in the center of each stand (Figs. 2.1 and 2.2) and all surveys of forest structure and biota were conducted in those central sites. Trees, snags, downed woody material, and understory vegetation were surveyed in a series of nested plots and transects (Fig. 2.3, see Chapters 3 - 5). Breeding birds were surveyed using a combination of point counts and strip transects (Chapter 7). Bats were surveyed using automatic remote bat detectors (Chapter 8). Post-harvest surveys of biota will be conducted during the spring and summers of 1998 and 1999 (Table 2.1, see Chapters 3 - 8).

\section{Analysis and Reporting}

All field work was coordinated by Troy Sorensen a full-time researcher at Alberta Research Council. Analyses and reporting was conducted during the fall and winter by researchers at Alberta Rèsearch Council, Vegreville, AB. 


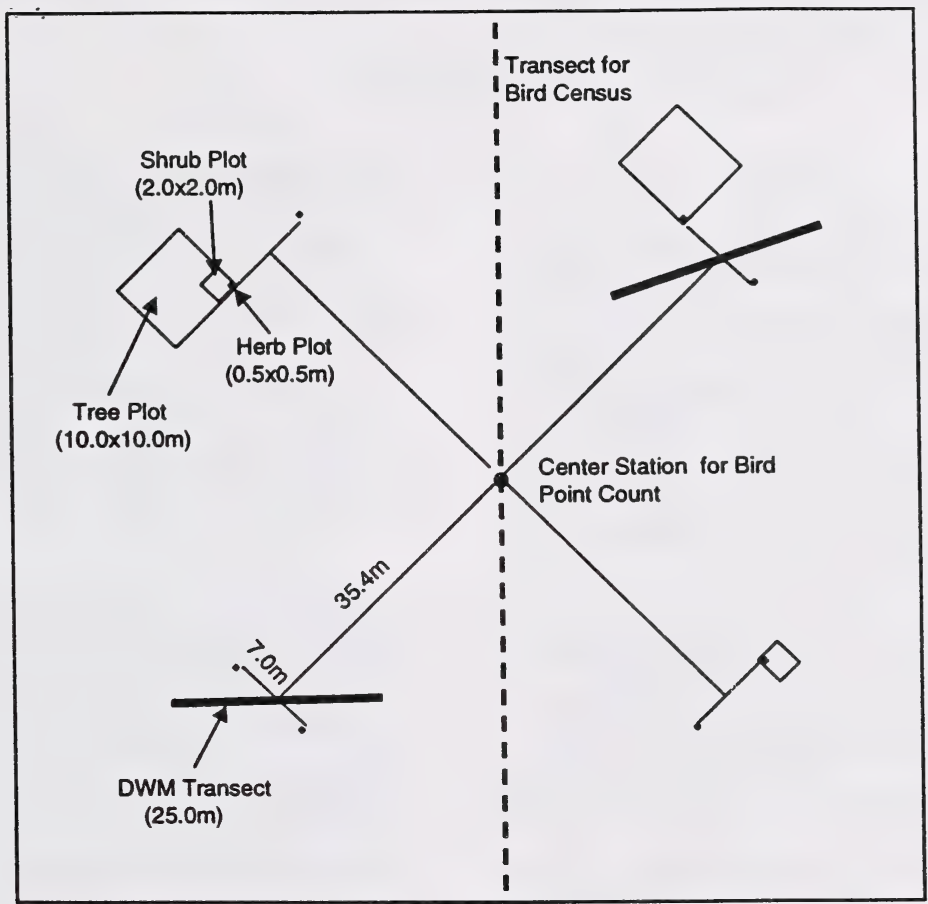

FIGURE 2.3. An example of the transect and nested-plot layout for a 1-ha (2.47 acre) site.

TABLE 2.1. Schedule by which forest structure and biota will be surveyed during the project.

\begin{tabular}{|c|c|c|c|}
\hline Element & $\begin{array}{c}1997 \\
\text { (Pre-Harvest) }\end{array}$ & $\begin{array}{c}1998 \\
\text { (Post-harvest) }\end{array}$ & $\begin{array}{c}1999 \\
\text { (Post-harvest) }\end{array}$ \\
\hline $\begin{array}{l}\text { Trees and Snags } \\
\text { Down woody Material } \\
\text { Understory Vegetation } \\
\text { Arthropods } \\
\text { Birds } \\
\text { Bats }\end{array}$ & $\begin{array}{c}\text { extensive survey } \\
\text { extensive survey } \\
\text { cursory survey } \\
\text { none } \\
\text { extensive survey } \\
\text { extensive survey }\end{array}$ & $\begin{array}{c}\text { extensive survey } \\
\text { cursory survey } \\
\text { none } \\
\text { extensive survey } \\
\text { cursory survey } \\
\text { extensive survey }\end{array}$ & $\begin{array}{c}\text { cursory survey } \\
\text { none } \\
\text { extensive survey } \\
\text { cursory survey } \\
\text { extensive survey } \\
\text { extensive survey }\end{array}$ \\
\hline
\end{tabular}




\title{
CHAPTER 3. TREES PRE-HARVEST CHARACTERISTICS AND COMPOSITION OF TREE AND SNAG COMMUNITIES IN GRANDE PRAIRIE AND WHITECOURT STUDY AREAS.
}

\author{
Susan Crites
}

\section{Introduction}

The natural disturbance model of ecosystem management assumes that biota are adapted to natural disturbances and are more likely to maintain viable populations if forest harvesting is as similar as possible to natural disturbances (Swanson and Franklin 1992). In Alberta's boreal mixedwood forests, fire is the dominant natural disturbance and is currently being used as a template for timber harvesting by some companies (Anonymous 1997).

Past research has demonstrated that species respond to forest structure (Stelfox 1995). Timber harvesting, which removes structure, will undoubtedly have negative consequences on biota that were present in the stand before it was harvested. Structure in the form of large trees and snags is often in abundance after fire, and its presence, mainly in the form of snags and downed woody material, is often seen long after the disturbance (Lee et al. 1997). To allow timber harvesting to more closely approximate fire, forest managers are advocating that residual merchantable material be left behind at harvest. The appropriate amount and distribution of residual material on cutblocks, however, is much debated. Clumps left behind at harvest could be compared to fire skips that serve as refugia and dispersal sites; therefore, larger clumps may function as better refugia. Conversely, residual material evenly distributed throughout a cutblock could serve to put structure into mature forests that is usually absent from harvest-origin forests until older ages, and that serves as habitat, cover, and foraging sites. Of the two patterns, it is not known which will be more beneficial to biota.

Trees species respond differently to wind depending on their structural integrity, decay properties, exposure to wind during development, and sheltering ability of surrounding vegetation. Trees sheltered within an intact forest tend to have smaller boles, branches concentrated in the canopy, and are not as strongly rooted in the soil as trees that have been exposed to wind during development.

Newly exposed residual trees left post-harvest are susceptible to the turbulent and accelerated wind in cutover areas because they have not developed the structural integrity to withstand such winds (Kimmins 1996).

Deciduous species such as aspen and balsam poplar are more likely to respond to wind by snapping off along the bole than to be root thrown. This is due to their concentration of branches in the canopy, the depth and complexity of their rooting system, and their susceptibility to fungal attack that weakens boles (Peterson and Peterson 1992). Coniferous species such as black and white spruce respond to wind by being root thrown. This is because of their shallow rooting system and high surface area (consisting of needles and branches) exposed to wind that extends the entire length of the bole.

Site conditions also influence the ability of trees to remain standing pre- and post-harvest. In soils saturated with water, root systems are poorly anchored and trees have the tendency to fall over. In addition, frost heaving can uplift trees from the soil. Season of harvest will influence root system stability and/or tree health in areas directly affected by equipment. Timber harvesting when the ground is not frozen can lead to soil compaction, and, if compaction is very high, it can kill root systems, leading to tree death.

In this report I evaluate the pre-harvest density and characteristics (i.e., species, heights, and diameters) of trees and snags among stand groups and treatments within each study area (see Chapter 2 for experimental design). Post- 
harvest, I will determine whether tree death and tree and snag fall down rates vary among treatments.

\section{Methods}

For a description of study areas and methods, see Chapter 2. Trees and snags were sampled in every second site in each stand. Each one ha sampling site was divided into four quadrants, and a $10 \times 10 \mathrm{~m}(11 \times 11 \mathrm{yd}$.) tree plot was placed in two randomly selected quadrants. Tree plots were located close to the centre of each quadrant (Fig. 2.3). Within each plot, density, diameter at breast height [1.4 m (4.6 $\mathrm{ft}$.)], height class [ $1=1.4-5 \mathrm{~m}(4.6-16.4 \mathrm{ft}$.), $2=$ 5.1-10 m (16.5-32.8 ft.), $3=10.1-20 \mathrm{~m}$ (32.9$65.6 \mathrm{ft}$.), $4=>20 \mathrm{~m}$ (>65.6 ft.)], top condition (broken canopy, broken bole, or intact) and species were recorded for trees and snags that were $\geq 1.4 \mathrm{~m}$ ( $\geq 4.6 \mathrm{ft}$.) tall. For snags, decay stage was also recorded (six stages from Lee et al. 1997; stage one being a recently killed tree, stage six being a broken off, well-decayed bole). Diameter distributions of trees and snags were plotted and evaluated to separate stems of the canopy cohort from stems of the subcanopy or understory. Only stems of the canopy cohort were used in analyses. For snags, "canopy" refers to trees greater than a particular diameter (see Results), irrespective of whether the stem is actually part of the canopy (i.e., broken off).

General Linear Models (GLM, SAS Institute, Inc. 1989) were used to evaluate differences in abundances of canopy trees and snags among stand groups and treatments. Analyses were completed on log transformed data. Post hoc tests were completed using Tukey's Honestly Significant Difference test (Zar 1984; SAS Institute, Inc. 1989). All results were considered statistically significant if the probability of them occurring by chance was less than 0.05 .

\section{Results}

\section{Live Trees}

A total of 2672 and 4802 trees and snags were sampled in Grande Prairie and Whitecourt, respectively. In Grande Prairie there were four tree species found during the surveys with aspen being the most common followed by balsam poplar, paper birch, and white spruce (Table 3.1). Seven species were found during the surveys in Whitecourt, with jack pine and black spruce being the most common followed by balsam fir, paper birch, aspen, white spruce, and balsam poplar (Table 3.1).

\section{Stem Diameter and Height}

Not surprisingly, stems increased in diameter as they increased in height. For both study areas, the majority of stems were short [1.4-5 m (4.6$16.4 \mathrm{ft})$.$] and in diameter class 0-5 \mathrm{~cm}(0-2 \mathrm{in}$.) (Figures 3.1 and 3.2). In Grande Prairie, the second most abundant diameter class was 15.1$20 \mathrm{~cm}$ (5.9-7.9 in.); therefore, canopy trees in Grande Prairie likely consisted of trees $>15 \mathrm{~cm}$ (>5.9 in.) dbh (Figure 3.1). The majority of trees with diameters $>15 \mathrm{~cm}$ ( $>5.9$ in.) were $>20$ $\mathrm{m}$ (>65.6 ft.) tall (Figure 3.1). By examining the relationship between diameter and height at Whitecourt, canopy trees likely consisted of trees $>10 \mathrm{~cm}$ (>3.9 in.) dbh (Fig. 3.2). Unlike trees in Grande Prairie, heights of canopy trees were between 10.1-20 m (32.9-65.6 ft.), with few $>20 \mathrm{~m}$ (>65.6 ft.) (Figure 3.2).

Only canopy trees, [i.e., stems $>10 \mathrm{~cm}$ ( $>3.9$ in.) and $>15 \mathrm{~cm}$ (>5.9 in.) dbh for Grande Prairie and Whitecourt, respectively] were used in subsequent analyses. Otherwise, the high frequencies of smaller trees in both study areas would dominate density calculations and interpretations.

\section{Canopy Stem Density}

Average number of canopy stems per hectare was $746.8( \pm 75.0 \mathrm{SE})[302.3( \pm 30.4 \mathrm{SE})$ stems/acre] and 1441.8 ( $\pm 123.5 \mathrm{SE})$ [583.7 $( \pm 50.0 \mathrm{SE})$ stems/acre] for Grande Prairie and Whitecourt, respectively. In Grande Prairie, aspen dominated all stand groups (Table 3.2). When all species were combined in Grande Prairie, there were no significant differences in stems per ha among stand groups or treatments (Table 3.2). For individual species in stand groups, lower densities of aspen and higher densities of balsam poplar were found in stand group C (Table 3.2). There were no differences among treatments for individual species (Table 3.2). 
TABLE 3.1. Percent species composition of trees and snags $\geq 1.4 \mathrm{~m}(\geq 4.6 \mathrm{ft}$.) in height in Grande Prairie and Whitecourt study areas. Numbers in parentheses indicate the actual number sampled.

\begin{tabular}{lccccc}
\hline & \multicolumn{2}{c}{ Trees } & & \multicolumn{2}{c}{ Snags } \\
\cline { 2 - 3 } \cline { 5 - 6 } Species & Grande Prairie & Whitecourt & & Grande Prairie & Whitecourt \\
\hline Populus tremuloides & $81(1937)$ & $2(79)$ & & $78(222)$ & $2(22)$ \\
Populus balsamifera & $8(194)$ & $0(2)$ & & $16(44)$ & 0 \\
Betula papyrifera & $6(137)$ & $19(726)$ & & $4(12)$ & $9(87)$ \\
Picea glauca & $5(121)$ & $2(74)$ & & $1(2)$ & $1(15)$ \\
Pinus banksiana & 0 & $27(1033)$ & & 0 & $34(335)$ \\
Abies balsamea & 0 & $22(828)$ & & 0 & $2(17)$ \\
Picea mariana & 0 & $28(1070)$ & & 0 & $51(507)$ \\
unknown & 0 & 0 & & $1(3)$ & $1(7)$ \\
Total (N) & $100(2389)$ & $100(3812)$ & $100(283)$ & $100(990)$ \\
\hline
\end{tabular}




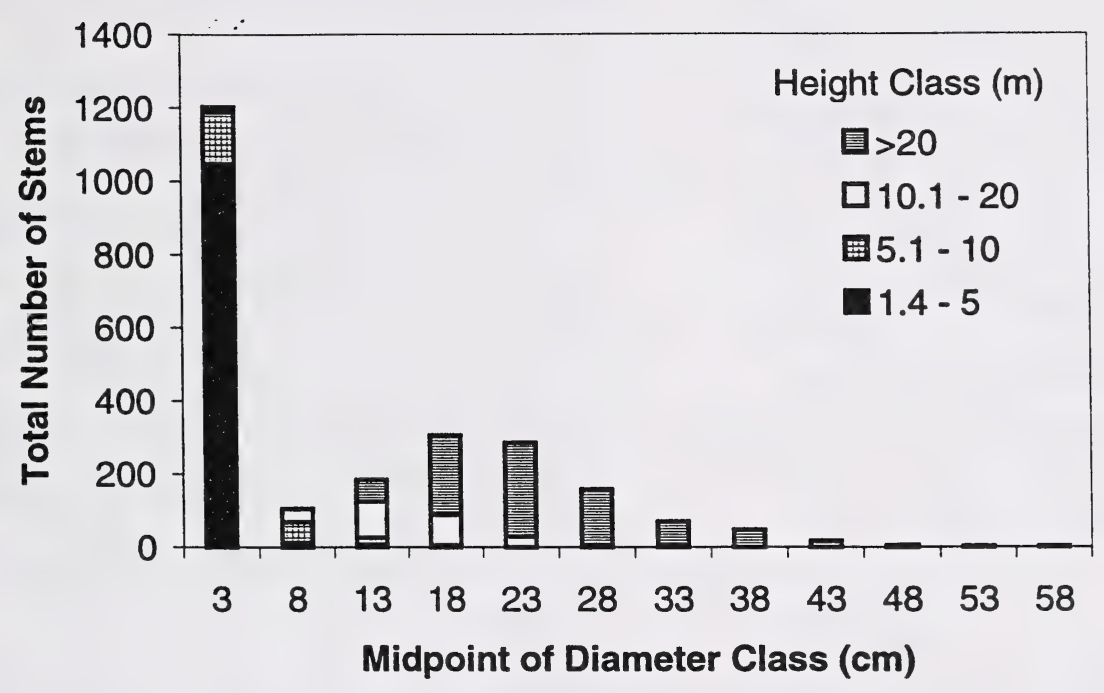

FIGURE 3.1. Total number of live trees categorized by diameter and height classes for Grande Prairie.

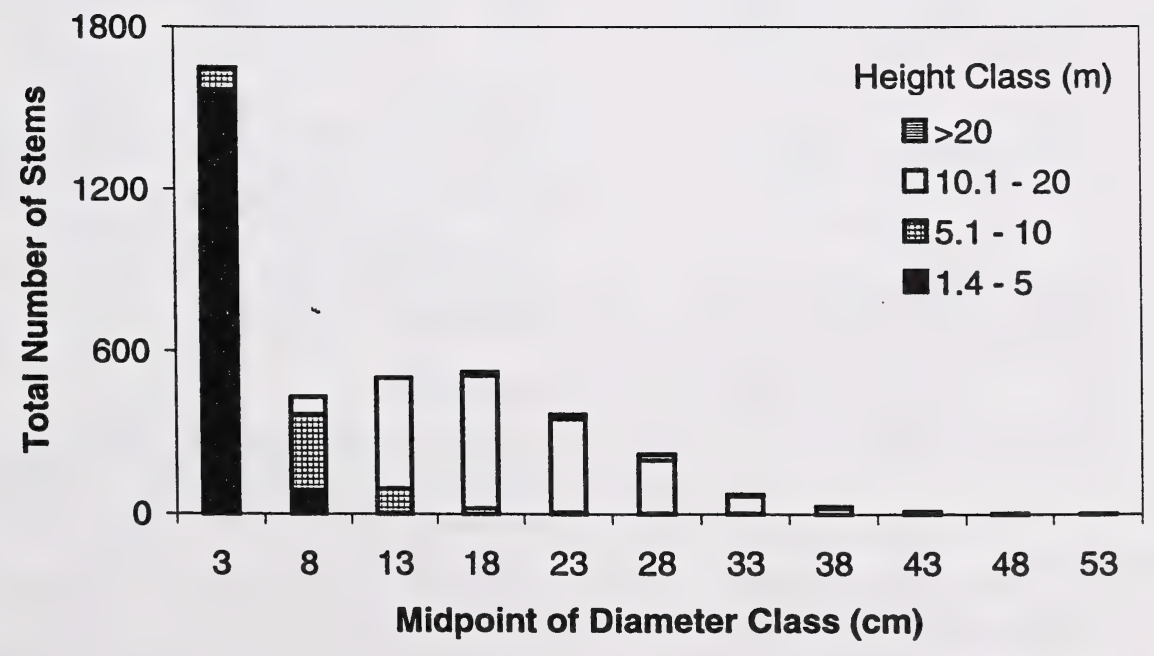

FIGURE 3.2. Total number of live trees categorized by diameter and height classes for Whitecourt. 
In Whitecourt, jack pine dominated all stand groups and treatments, followed closely by black spruce. For all species combined in Whitecourt, stand group A had the highest stem densities and stand group B the lowest (Table 3.3). Jack pine and black spruce were present in higher densities in Stand group A, and in lower densities in stand group $\mathrm{B}$, than in remaining stand groups. On the other hand, white spruce and balsam fir were present in higher densities in stand group B than in remaining stand groups, but these densities were relatively low (Table 3.3). When all stems were combined, there were no significant differences among treatments in Whitecourt; however, aspen was present in higher densities in treatment one than in remaining treatments, and white spruce was absent from treatment three (Table 3.3).

\section{Snags}

Of the total number of stems sampled, $11 \%$ (283) and $21 \%$ (990) were snags in Grande Prairie and Whitecourt, respectively. Dominant snag species were the same as the dominant tree species for each of the two locations. There were no paper birch snags of canopy size in Grande Prairie, and no balsam poplar snags in Whitecourt.

\section{Snag Diameter}

Diameter distributions for snags were different than for live trees for both study areas. The snag distribution in Grande Prairie peaked at 10.1-15 cm (4-5.8 in.) dbh (Figure 3.3), whereas in Whitecourt, the distribution was high from 0 $10 \mathrm{~cm}(0-3.9 \mathrm{in}$.) $\mathrm{dbh}$, then decreased to very few trees $>30 \mathrm{~cm}$ (>11.8 in.) (Figure 3.4). Height measurements for snags are not presented because many snags snapped along the bole. The same diameter cut offs as used for canopy trees was used for the snag analyses (i.e., $>15 \mathrm{~cm}$ ( $>5.9$ in.) and $>10 \mathrm{~cm}$ (>3.9 in.) $\mathrm{dbh}$ for Grande Prairie and Whitecourt, respectively).

\section{Canopy Snag Density}

There was a mean of $77.5( \pm 19.2 \mathrm{SE})$ [31.4 ( $\pm 7.8 \mathrm{SE})$ per acre] and 289.3 ( $\pm 44.8 \mathrm{SE}$ ) [117 $( \pm 18 \mathrm{SE})$ per acre] large snags per hectare in Grande Prairie and Whitecourt, respectively. In Grande Prairie, density of snags did not vary significantly among groups for all species combined (Table 3.2); however, balsam poplar and birch had significantly higher densities in stand group $\mathrm{C}$ compared to remaining groups (Table 3.2). Density of large snags did not vary significantly among treatments (Table 3.2).

Similar to tree density, density of large snags in Whitecourt varied significantly among groups when all species were combined, with stand group B having the lowest density of snags and stand group A the highest (Table 3.3). The low density of snags in stand group B was due to the low densities of jack pine snags (Table 3.3). Density of black spruce snags was significantly higher in stand group A as compared to remaining stand groups (Table 3.3). Densities of large snags did not vary among treatments for all species combined, but for individual species, density of balsam fir snags was higher in treatment two, than in remaining treatments (Table 3.3).

\section{Decay}

In all dbh classes, snag density tended to decrease as decay state increased (Fig. 3.3 and 3.4). More than $50 \%$ of the snags in Grande Prairie have decay stage of one, with $82 \%$ of the snags being in decay stages one, two, and three (Figure 3.3). In Whitecourt $50 \%$ of the snags were within decay stages one or two and $95 \%$ of snags were in the first four decay stages (Figure 3.4).

\section{Top Condition}

Of all snags sampled, $66.2 \%$ and $67.5 \%$ had intact boles in Grande Prairie and Whitecourt, respectively. In Grande Prairie, $26.6 \%$ of snags had broken boles and $7.2 \%$ had broken canopies, compared to $16.6 \%$ and $15.9 \%$ in Whitecourt, respectively.

\section{Discussion}

Composition and characteristics of the tree and snag communities were different between the two study areas. Grande Prairie was an aspendominated community with canopy trees commonly reaching heights greater than $20 \mathrm{~m}$ $(65.6 \mathrm{ft}$.) and diameters greater than $15 \mathrm{~cm}(5.9$ in.) dbh. The community was homogeneous with only four species and having aspen dominate all groups and treatments. The 


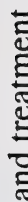

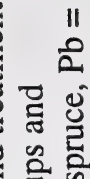

응

을

交 11

o s 3

항

ᄃ

ㅇㅇㅇ

.

洁

30

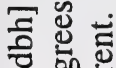

원

웅

는즐

달

ह

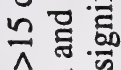

$\Lambda$.

능응

I

范

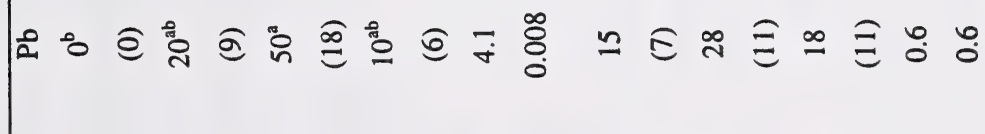

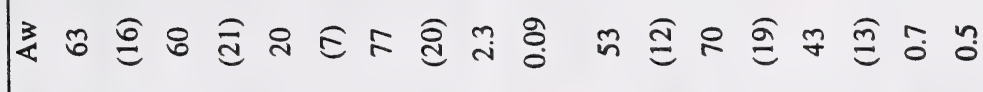

ॠ

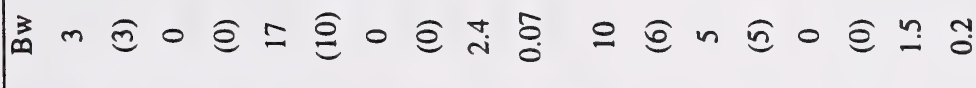

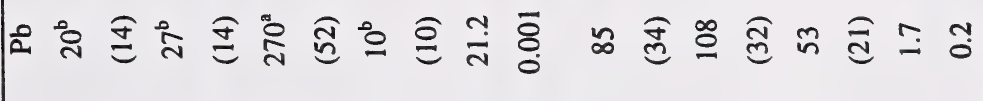

온

है

\& \&

는

증항

잉응

흔

응

的密

원

$\$ 3$

总总

政

형

闰绍

要

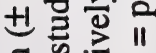

동

政

政

त

๗

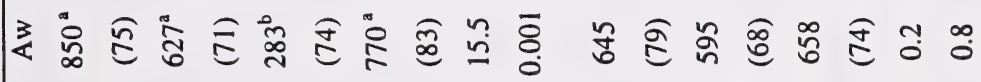

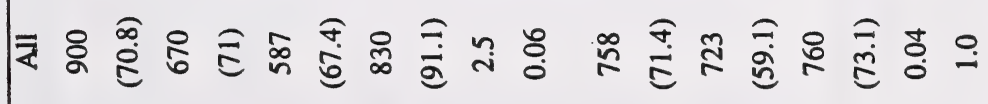

成骂

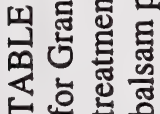


芩

을 응 난 110

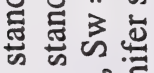
등 का 당 I 은 政 3 这 응 (1) 三 a 숭응 트를 웡 드에

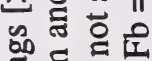
(I. s.

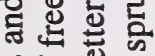
पु 舟 入

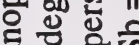

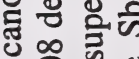
눙응 물 兘兽 so 总部 पू 을 田的 罗焉 से 을 3 क्ष 2 둥

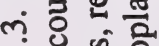
问总 띤

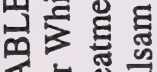
点总

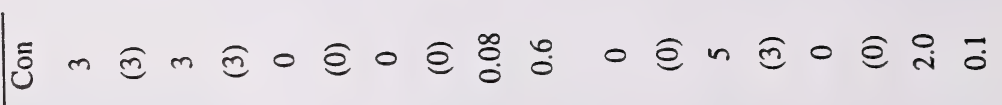

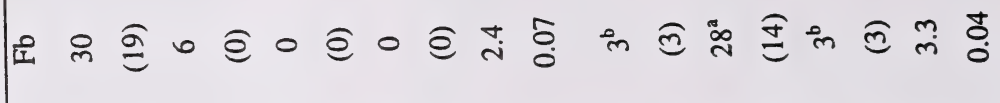

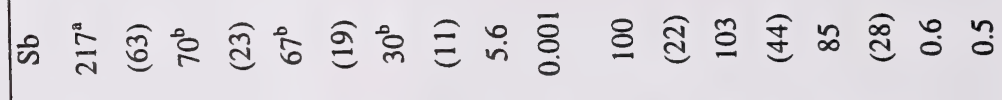

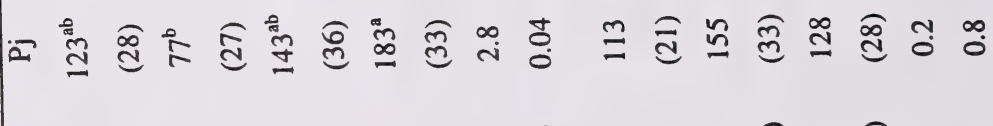

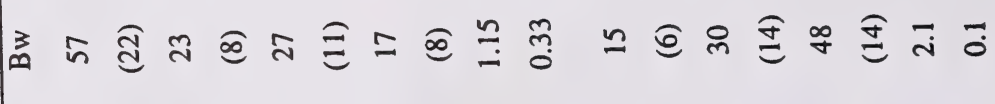

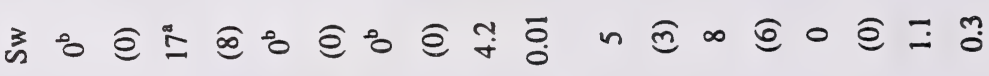

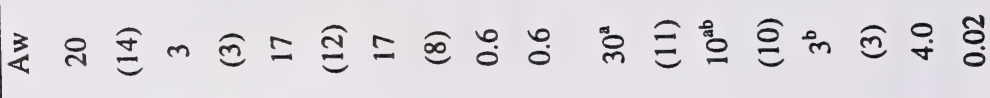

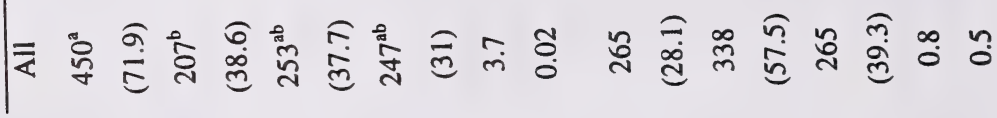

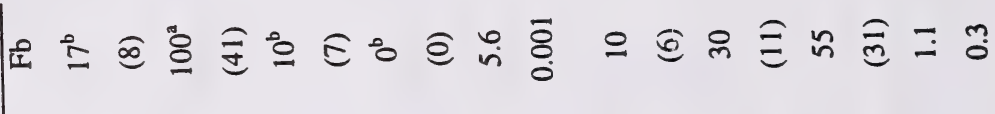

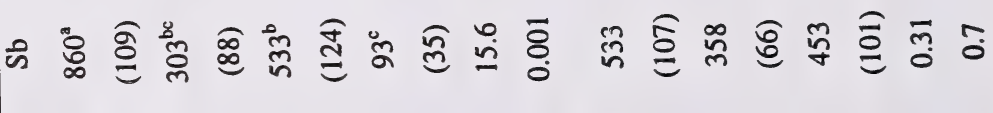

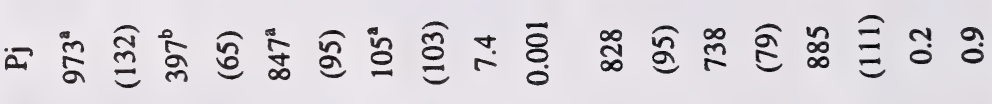

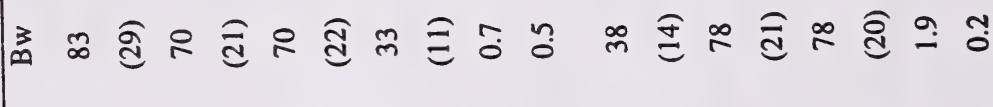

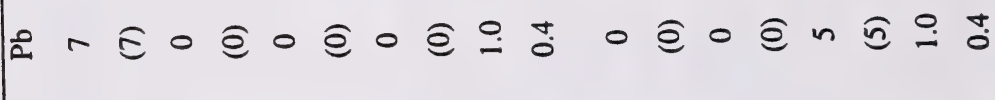

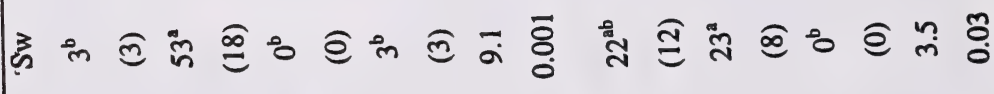

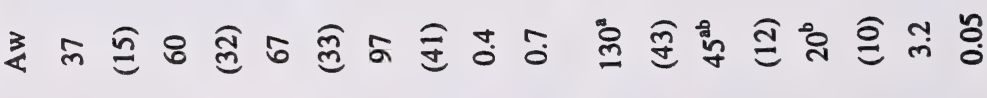

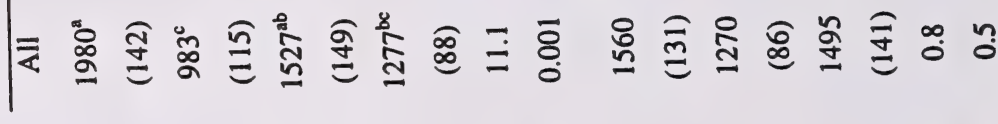

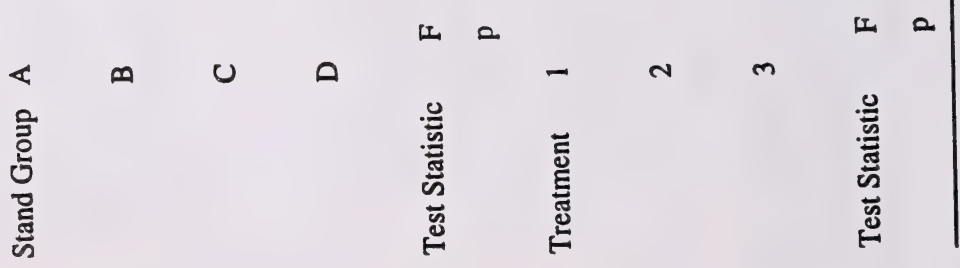




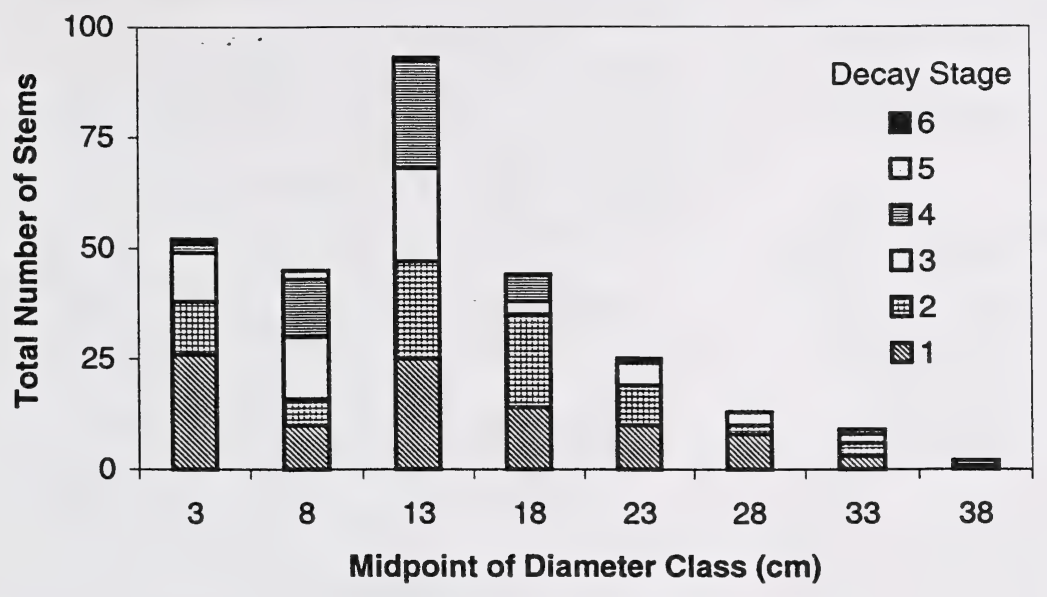

FIGURE 3.3. Total number of snags categorized by diameter class and decay stage for Grande Prairie. Decay stage one refers to a recently dead tree; decay stage six refers to a well-decayed snag that is soft in places with a broken bole.

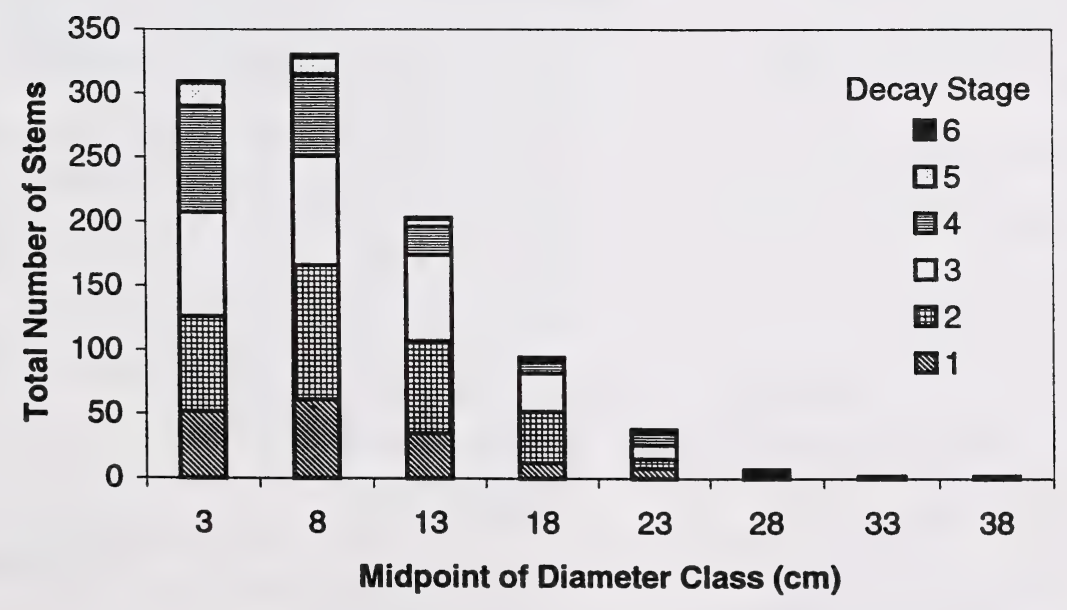

FIGURE 3.4. Total number of snags categorized by diameter class and decay stage for Whitecourt. Decay stage one refers to a recently dead tree; decay stage six refers to a welldecayed snag that is soft in places with a broken bole. 
High densities of trees in small diameter classes indicates trees are continually being recruited into the understory and subcanopy. If gaps form in the canopy, these understory trees may grow to become part of the canopy. If no gaps form before these understory trees are out-competed, they will become snags.

As with trees, aspen also dominated the snag community in Grande Prairie resulting in snags with a greater frequency of broken boles than snags in Whitecourt. The self-thinning nature of aspen stands is represented in the median snag diameter of 10.1-15 cm (4-5.9 in.)in Grande Prairie, which is one diameter class lower than the median diameter class for live canopy trees [15.1-18 cm (6.0-7.1 in.) dbh]. As aspen stands grow, they compete for resources and continue to self-thin until they reach mature ages and canopy equilibrium is obtained (Peterson and Peterson 1992). As a result, snags are continuously being recruited into diameter classes smaller than the canopy live trees. Decay stage one was the most common decay stage for all snag sizes, with the exception of snags having a dbh of 5.1-10 cm (2.1-3.9 in.), and snags greater than $30 \mathrm{~cm}$ (11.8 in.) dbh. Surprisingly, many snags that are $5.1-15 \mathrm{~cm}$ (2.1-5.9 in.) dbh have been present long enough to have decayed to stages three, four, and five.

The tree community in Whitecourt was more heterogeneous than in Grande Prairie with two species, jack pine and black spruce, dominating and eight species present. Canopy trees in Whitecourt were shorter and had smaller dbh than canopy trees in Grande Prairie. As in Grande Prairie, trees in Whitecourt were abundant in small diameter classes, indicating a high recruitment of trees into the understory and subcanopy. The fate of these trees will depend on canopy gap formation and competition dynamics between tree species. Tree species richness was high in Whitecourt, leading to different potential successional patterns than found in Grande Prairie. Balsam fir and paper birch were common in the understory of many stands. Balsam fir is a late successional shadetolerant species that, in the absence of disturbance, may eventually replace the current canopy cohort and form a 'climax' community (Kimmins 1996).
Based on vegetation within and surrounding stands, each stand was assigned to one of four stand groups. Stand groupings accounted for a small amount of variation in the tree and snag communities of both study areas. In addition to having fewer species, the tree and snag community in Grande Prairie exhibited fewer differences between groups than in Whitecourt, indicating that this community was more homogeneous.

There were no differences among treatments for tree and snag communities in Grande Prairie. In Whitecourt, there were differences among treatments for aspen and white spruce live trees, and for aspen and balsam fir snags. When examining the Grande Prairie community postharvest, any differences in the tree and snag communities among the different residual patches will be attributed to the harvesting treatment, and not due to any pre-harvest differences. In Whitecourt, any post-harvest differences in the tree and snag communities will have to be evaluated after taking into account the differences among treatments prior to harvest.

\section{Future Research}

Tree and snag communities will be surveyed and monitored in 1998 and 1999. In spring of 1998, all residual trees and snags will be permanently marked within a subset of randomly selected patches. In addition, a subset of snags and trees in the cut-over area will be marked. The fate of this residual material will be regularly determined in the summer of 1998 and 1999. In 1999, I will determine which configuration of patch size and dispersion is most beneficial to the long-term persistence of standing trees and snags.

\section{Literature cited}

\section{Anonymous. 1997. Alberta Pacific Forest Industries, Inc. Detailed Forest Management Plan. 143 pp.}

Kimmins, J.P. 1996. Forest Ecology: A Foundation for Sustainable Management. $2^{\text {nd }}$ edition. Prentice Hall. Upper Saddle River, NJ. 
Lee, P.C., Crites, S., Nietfeld, M., Van Nguyen, H., and Stelfox, J.B. 1997. Characteristics and origins of deadwood material in aspendominated boreal forests. Ecological Applications 7:691-701.

Peterson, E.B. and Peterson, N. M. 1992. Ecology, management, and use of aspen and balsam poplar in the Prairie Provinces, Canada. Forestry Canada, Northwest Region, Northern Forestry Centre, Edmonton, AB.

Special Report 1.

SAS Institute, Inc. 1989. SAS/SYSTAT User's Guide, Version 6, Fourth edition, Volume 1 and 2. SAS Institute Inc., Cary, NC.

Stelfox, J.B. Editor. 1995. Relationships between stand age, stand structure, and biodiversity in aspen mixedwood forests in Alberta. Jointly published by the Alberta Environmental Centre (AECV95-R1) and the Canadian Forest Service (Project No. 0001A), Edmonton.

Swanson, F.J. and Franklin, J.F. 1992. New forestry principles from ecosystem analysis of Pacific Northwest forests. Ecological Applications 2:262-274.

Zar, J.H. 1984. Biostatistical Analysis, $2^{\text {nd }}$ edition. Prentice Hall, New Jersey. 


\title{
CHAPTER 4. CHARACTERISTICS OF DOWNED WOODY MATERIAL IN RELATION TO THE DISPERSION OF RESIDUAL TREES FOLLOWING HARVEST
}

\author{
Troy C. Sorensen
}

\section{Introduction}

Bryophytes, lichens, fungi, invertebrates, and herbaceous plants compose the majority of biodiversity in an ecosystem. Many of these taxa are influenced by, or dependent on, the abundance, size, spatial distribution, and decomposition of downed woody material (DWM; McCullough 1948; Thompson 1980; Harmon et al. 1986; Söderström 1988a,b; Crites and Dale 1995, in press). DWM is also crucial as nest sites (Thompson 1980), food, and protection for vertebrates and invertebrates (Harmon et al. 1986). In addition to its direct influence on biodiversity, DWM functions as an important reservoir for ecosystem nutrients (Lambert et al. 1980, MacMillan 1981, Abbott and Crossley 1982, Harmon et al. 1986).

Large DWM in a wide range of decay stages is often stressed as important in maintaining the species composition of DWM-dependent taxa (Söderström 1988a,b; Lesica et al. 1991; Crites and Dale 1995, in press). Clearcutting, however, reduces the density, volume, size distributions (Abbott and Crossley 1982; Lesica et al. 1991) and decay class distributions of DWM (Söderström 1988a,b; Crites and Dale 1995, in press; Lee et al. 1995, 1997). One strategy to minimize these effects is to leave residual live trees, snags, and DWM in harvested areas (Lee et al. 1995, 1997) in an effort to promote natural size and decay class distributions of DWM, and the establishment of DWM-dependent taxa (Söderström 1988b). If forest managers are willing to leave this residual material, the question remains of how to distribute it within harvested areas. An even spatial distribution of DWM will facilitate the dispersal of DWM-dependent species, but will minimize the amount of interior-forest environment which promotes natural decomposition rates of DWM.

Currently this study has two objectives: 1) to provide pre-harvest information on the amount and characteristics DWM in the two study areas and 2) to test for differences in DWM among stand groups prior to harvest. During 1998-99, post-harvest density, volume, spatial distribution, and decomposition of DWM will be surveyed and compared among stand treatments. Current results will be used to account for pre-harvest differences among stands.

\section{Methods}

A description of the study areas and experimental harvesting is presented in Study Area and Methods (Chapter 2). Ten 1-ha (2.47 acre) sites were established in the center [ $\mathrm{ca}$. $100 \mathrm{~m}$ (109 yd.) from the edge] of each stand and all surveys for biota were conducted within those sites (Fig. 2.1 and 2.2). DWM was surveyed along two $25 \mathrm{~m}$ (27 yd.) transects within the center of two randomly selected quadrants of each site (Fig. 2.3). The direction of each transect was random. All DWM intersecting the transect with diameters $\geq 5 \mathrm{~cm}$ ( $\geq 2$ in.) were tallied; in addition, the diameter at line intersect and decay class (Table 4.1) of large pieces $[\geq 10 \mathrm{~cm}(\geq 4 \mathrm{in}$.)] were measured. DWM with diameters between $5-10 \mathrm{~cm}(2-4$ in.) and $\geq 10 \mathrm{~cm}(\geq 4 \mathrm{in}$.) will be called small and large DWM, respectively.

The 12 stands in both study areas were assigned into 4 groups to group stands that had the most similar tree composition. The three stands in each group were then randomly assigned a treatment of residual tree dispersion (see Chapter 2). Harvesting occurred during the winter of 1997-98.

Linear densities of DWM were calculated as the number of pieces per $5 \mathrm{~m}(16 \mathrm{ft}$.) of transect and are referred to in the rest of this chapter as densities. The volume of DWM per unit area 
TABLE 4.1. Descriptions of decay classes (modified from Lee et al. 1997) assigned to large [ $>10 \mathrm{~cm}(>4$ in.) diameter] DWM.

Decay Classes

DWM Characteristics

$1 \quad$ Log whole and undecayed; bark, branches, and twigs present and intact; log elevated on support points; wood hard.

2 Log sound, wood hard; twigs mostly lacking; $<50 \%$ of the bark missing

3 Wood soft in places; some branches remaining; $>50 \%$ bark missing; wood soft in places

$4 \quad$ Little to no bark remaining; no branches; wood fungi present; wood soft with small crevices and small pieces lost.

5 Large wood fragments lost; outline of trunk slightly deformed; vascular and non-vascular plants beginning to colonize.

6 Wood mostly well-decayed; log colonized by various vascular and non-vascular plants.

7 Humification nearly $100 \%$; hard to define as log, outline indeterminable; no evidence of hard wood. 
(v) was calculated from the following formula (Van Wagner 1968):

$$
v=\frac{\pi^{2} \sum_{i=1} d_{i}^{2}}{8 l}
$$

where $l$ is the transect length [25 $\mathrm{m}$ (27 yd.)], $d$ is the diameter $(\mathrm{cm})$ of the large pieces $[>10 \mathrm{~cm}$ ( $>4$ in.)] or $7.5 \mathrm{~cm}$ (3 in.) for small pieces [5-10 $\mathrm{cm}(2-4 \mathrm{in}$.)], and $i$ is the number of pieces intersecting the transect. The resulting units are cubic meters per hectare. Densities and volumes were calculated for both small and large pieces and then summed for a total value. Volume was also calculated for each decay class (1-7) of the large pieces. The species composition of DWM was not analyzed because it should be directly related to the species composition of trees and snags (Chapter 3).

General Linear Models (GLM, SPSS 1997) were used to examine differences in the densities and volume of DWM between stand groups and treatments. Tukey's Honestly Significant Difference tests $(\alpha=0.05)$ were used for all post hoc tests (Zar 1984; SPSS 1997). Volumes of small DWM were not analyzed separately because they were proportionally related to small DWM densities. The spatial heterogeneity of DWM distribution was examined by using a nested design (sites within stands).

\section{Results}

\section{Grande Prairie Study Area DWM Densities}

There was $0.99 \pm 0.08$ SE pieces of small DWM and $0.94 \pm 0.06$ pieces of large DWM every $5 \mathrm{~m}$ (16 ft.) in the Grande Prairie study area. DWM density differed among stand groups for small $\left(F_{3.108}=4.558, p=0.005\right)$, large $\left(F_{3.108}=2.690, p\right.$ $=0.050)$, and total DWM $\left(F_{3.108}=6.177, p=\right.$ 0.001; Table 4.2). Higher densities of DWM were found in stand groups near bog areas (Group A and D, Table 4.2, Fig. 2.2).

There was no significant difference in the densities of large $\left(F_{2,108}=0.027, p=0.973\right)$ or total DWM $\left(F_{2.108}=1.930, p=0.150\right)$ between treatments; however, there was a significant difference between treatments in the density of small DWM $\left(F_{2,108}=3.800, p=0.025\right.$, Table 4.2).

The spatial distribution of DWM density was heterogeneous within and among stands. Small and large DWM densities were spatially heterogeneic both within $\left(F_{108,120} \geq 1.641, p \leq\right.$ $0.004)$ and among stands $\left(F_{6,108} \geq 2.357, p \leq\right.$ 0.035 ). On the other hand, total DWM density was significantly different within stands $\left(F_{108,120}\right.$ $=1.927, p=0.0002)$ but not among stands $\left(F_{6,108}\right.$ $=1.757, p=0.115)$.

\section{DWM Volume}

There was $77.4 \mathrm{~m}^{3} / \mathrm{ha}( \pm 5.1 \mathrm{SE})\left[41.0 \mathrm{yd}^{3} / \mathrm{acre}\right.$ $( \pm 2.7 S E)]$ of DWM in the Grande Prairie study area. Volume differed among stand groups $\left(F_{3,108}=2.952, p=0.036\right.$, Table 4.3) with group $\mathrm{B}$ having lower total DWM volume than other groups (Table 4.3); potentially due to their farther distance from bogs and wet areas (Fig. 2.2). The volume of large DWM did not differ among stand groups $\left(F_{3.108}=2.487, p=0.064\right.$, Table 4.3). The volume of large and total DWM did not differ among stand treatments prior to harvest $\left(F_{2,108} \leq 0.903, p \geq 0.408\right.$, Table 4.3).

The spatial distribution of large DWM volume was heterogeneous both within $\left(F_{108,120}=1.531\right.$, $p=0.012)$ and among $\left(F_{6.108}=2.382, p=0.034\right)$ stands; however, total DWM volume was heterogeneous within stands $\left(F_{108,120}=1.584, p=\right.$ 0.007 ) but not among stands $F_{0,108}=1.981, p=$ 0.075).

\section{DWM Size}

The average diameter of large DWM in the Grande Prairie study area was $15.5 \mathrm{~cm}$ ( \pm $0.47 \mathrm{SE})[6.1$ in. $( \pm 0.19 \mathrm{SE})]$. However the sizes of DWM had a negative exponential distribution (Fig 4.1).

The diameter of large DWM varied among stand groups $\left(F_{3.144}=4.942, p=0.003\right)$ and treatments $\left(F_{2.151}=3.415, p=0.035\right.$; Table 4.4) 
TABLE 4.2. Average linear density of DWM $( \pm S E)$ among stand groups in both study areas. Superscripts denote homogeneous subsets as determined by Tukey's Honestly Significant Difference $(\alpha=0.05)$ for significant comparisons among groups/treatments.

Linear Density (number / 5m)

Small DWM $\quad$ Large DWM $\quad$ Total DWM

Grande Prairie Area

$\begin{array}{ccccc}\text { Group } & \text { A } & 1.24 \pm 0.18^{\mathrm{a}} & 1.09 \pm 0.10^{\mathrm{a}} & 2.33 \pm 0.24^{\mathrm{a}} \\ & \mathrm{B} & 0.80 \pm 0.15^{\mathrm{b}} & 0.78 \pm 0.12^{\mathrm{b}} & 1.58 \pm 0.10^{\mathrm{b}} \\ & \mathrm{C} & 0.90 \pm 0.06^{\mathrm{b}} & 0.89 \pm 0.11^{\mathrm{ab}} & 1.79 \pm 0.13^{\mathrm{bc}} \\ & \mathrm{D} & 1.01 \pm 0.17^{\mathrm{ab}} & 0.99 \pm 0.11^{\mathrm{ab}} & 2.00 \pm 0.19^{\circ \mathrm{c}} \\ \text { Treatment } & 1 & 1.06 \pm 0.16^{\mathrm{a}} & 0.95 \pm 0.02 & \\ & 2 & 0.82 \pm 0.09^{\mathrm{b}} & 0.93 \pm 0.06 & 1.75 \pm 0.15 \\ & 3 & 1.09 \pm 0.14^{\mathrm{a}} & 0.93 \pm 0.18 & 2.02 \pm 0.28\end{array}$

Whitecourt Area

\begin{tabular}{ccccc} 
Group & A & $1.16 \pm 0.09^{\mathrm{a}}$ & $1.16 \pm 0.06^{\mathrm{a}}$ & $2.32 \pm 0.11^{\mathrm{a}}$ \\
& $\mathrm{B}$ & $0.85 \pm 0.19^{\mathrm{b}}$ & $2.02 \pm 0.53^{\mathrm{b}}$ & $2.87 \pm 0.63^{\mathrm{b}}$ \\
& $\mathrm{C}$ & $1.35 \pm 0.17^{\mathrm{a}}$ & $1.42 \pm 0.20^{\mathrm{ac}}$ & $2.77 \pm 0.03^{\mathrm{b}}$ \\
& $\mathrm{D}$ & $1.08 \pm 0.09^{\mathrm{ab}}$ & $1.70 \pm 0.36^{\mathrm{c}}$ & $2.77 \pm 0.37^{\mathrm{b}}$ \\
Treatment & 1 & $1.18 \pm 0.17$ & $1.38 \pm 0.32^{\mathrm{a}}$ & \\
& 2 & $1.07 \pm 0.04$ & $1.74 \pm 0.43^{\mathrm{b}}$ & $2.86 \pm 0.29$ \\
& 3 & $1.08 \pm 0.20$ & $1.59 \pm 0.16^{\mathrm{ab}}$ & $2.67 \pm 0.11$ \\
\hline
\end{tabular}


TABLE 4.3. Average volume per unit area of DWM ( \pm SE) among stand groups in both study areas. Superscripts denote homogeneous subsets as determined by Tukey's Honestly Significant Difference $(\alpha=0.05)$.

\begin{tabular}{ccc}
\multicolumn{3}{c}{ Volume $\left(\mathrm{m}^{3} / \mathrm{ha}\right)$} \\
\hline Small DWM & Large DWM & Total DWM
\end{tabular}

Grande Prairie Area

$\begin{array}{cccll}\text { Group } & \text { A } & 17.3 \pm 2.5^{\mathrm{a}} & 62.7 \pm 6.7 & 80.0 \pm 4.7^{\mathrm{ab}} \\ & \text { B } & 11.1 \pm 2.0^{\mathrm{b}} & 47.9 \pm 12.9 & 59.0 \pm 10.8^{\mathrm{a}} \\ & \text { C } & 12.5 \pm 0.8^{\mathrm{b}} & 74.1 \pm 9.4 & 86.7 \pm 9.2^{\mathrm{b}} \\ & \text { D } & 14.1 \pm 2.4^{\mathrm{ab}} & 69.8 \pm 11.3 & 83.8 \pm 10.7^{\mathrm{b}} \\ \text { Treatment } & 1 & 14.7 \pm 2.2^{\mathrm{a}} & 63.5 \pm 8.3 & \\ & 2 & 11.3 \pm 1.3^{\mathrm{b}} & 69.7 \pm 4.4 & 81.0 \pm 7.5 \\ & 3 & 15.2 \pm 2.0^{\mathrm{a}} & 57.7 \pm 14.1 & 72.9 \pm 13.8\end{array}$

Whitecourt Area

$\begin{array}{ccccc}\text { Group } & \text { A } & 16.1 \pm 1.2^{\mathrm{a}} & 88.1 \pm 6.7^{\mathrm{a}} & 104.2 \pm 7.0^{\mathrm{a}} \\ & \text { B } & 11.8 \pm 2.6^{\mathrm{b}} & 239.6 \pm 8.4^{\mathrm{b}} & 251.4 \pm 58.9^{\mathrm{b}} \\ & \text { C } & 18.7 \pm 2.4^{\mathrm{a}} & 128.8 \pm 9.5^{\mathrm{c}} & 147.5 \pm 27.3^{\mathrm{c}} \\ & \text { D } & 14.9 \pm 1.2^{\mathrm{b}} & 164.3 \pm 54.0^{\mathrm{c}} & 179.2 \pm 54.0^{\mathrm{c}} \\ \text { Treatment } & 1 & 16.3 \pm 2.4 & 136.8 \pm 43.1 & 153.1 \pm 42.0 \\ & 2 & 14.9 \pm 0.5 & 170.8 \pm 58.2 & 185.7 \pm 58.6 \\ & 3 & 14.9 \pm 2.7 & 158.0 \pm 35.7 & 172.9 \pm 33.2\end{array}$


with larger DWM in group $\mathrm{C}$ and treatment 2 (Table 4.4).

\section{DWM Decay Classes}

Very little of the large DWM was undecayed (decay class 1, Fig. 4.2). The proportion of DWM lying on the ground (76.3\%) was higher for more decomposed DWM (Fig. 4.2). The decay class distribution of total DWM volume did not differ among stand groups (Fig. 4.3) nor among treatments (Fig. 4.4).

\section{Whitecourt Study Area \\ DWM Densities}

There was $1.11 \pm 0.08 \mathrm{SE}$ pieces of small DWM and $1.57 \pm 0.17$ SE pieces of large DWM every $5 \mathrm{~m}$ in the Whitecourt study area. Density differed among stand groups (Table 4.2) for small $\left(F_{3,108}=4.233, p=0.007\right)$, large $\left(F_{3,108}=\right.$ $\left.17.616, p=2.22 \times 10^{-9}\right)$, and total DWM $\left(F_{3,108}=\right.$ $3.106, p=0.030$ ). Low densities for large and total DWM occurred in stands farthest from riparian/creek areas (Group A, Table 4.2, Fig. 2.1).

Varied results occurred when comparing the densities of DWM between stand treatments Table 4.2). There was no significant difference in the density of small $\left(F_{2,108}=0.466, p=0.629\right)$ or total DWM $\left(F_{2,108}=1.138, p=0.324\right)$ among treatments; however, there was a difference in the density of large DWM among treatments $\left(F_{2,108}=5.646, p=0.005\right.$, Table 4.2). These differences are probably due to the high density of large DWM in B2 [2.97/5 m (5.5 yd.)

$\pm 0.18 \mathrm{SE}]$ as a result of windfall (pers. obs.).

Small, large, and total DWM densities were heterogeneic among stands $\left(F_{6,108} \geq 2.445, p \leq\right.$ 0.030 ) but only small DWM densities were spatially heterogeneic within stands $\left(F_{108,120}=\right.$ 1.441, $p=0.026$; large and total DWM, $p \geq$ 0.056).

\section{DWM Volume}

There was $170.6 \mathrm{~m}^{3} / \mathrm{ha}( \pm 24.3 \mathrm{SE})$ [90.1 $\mathrm{yd}^{3} /$ acre $\left.( \pm 12.9 \mathrm{SE})\right]$ of DWM in the Whitecourt study area. DWM volume differed among stand groups for large $\left(F_{3,108}=20.568, p=1.29 \times 10^{-19}\right)$ and total DWM $\left(F_{3.108}=18.858, p=6.58 \times 10^{-19}\right)$ with group A having the lowest volume and group B having the highest volume (Table 4.3). Windfall in stand B2 was most likely the cause for the extremely high volume of large [330.7 $\left.\mathrm{m}^{3} / \mathrm{ha} \pm 20.7 \mathrm{SE}\left(175.1 \mathrm{yd}^{3} / \mathrm{acre} \pm 11.0 \mathrm{SE}\right)\right]$ and total DWM [346.4 $\mathrm{m}^{3} / \mathrm{ha} \pm 20.8$.SE (183.4 $\mathrm{yd}^{3} /$ acre $\left.\left.\pm 11.0 \mathrm{SE}\right)\right]$. The volume of large $\left(F_{2,108}\right.$ $=1.956, p=0.146)$ and total DWM $\left(F_{2,108}=\right.$ $1.759, p=0.177)$ did not differ among treatments (Table 4.3).

The spatial distribution of large and total DWM volume was heterogeneous both within $\left(F_{108,120} \geq\right.$ $\left.2.105, p \leq 4.01 \times 10^{-5}\right)$ and among stands $\left(F_{6,108} \geq\right.$ $11.160, p \leq 1.16 \times 10^{-9}$ ).

\section{DWM Size}

The average diameter of large DWM in the Whitecourt study area was $17.7 \mathrm{~cm}( \pm 0.60 \mathrm{SE})$ [7.0 in. $( \pm 0.24 S E)]$; however the sizes of DWM had a negative exponential distribution (Fig. 4.5). Most of the woody material (volume) constituted pieces with diameters of $10-30 \mathrm{~cm}$ (4-12 in.) (Fig. 4.5).

The diameter of large DWM differed among stand groups $\left(F_{3,144}=15.054, p=1.418 \times 10^{-8}\right.$; Table 4.4) with group A having the smallest and group B having the largest DWM (Table 4.4). Diameter of large DWM did not differ among stand treatments $\left(F_{2,148}=0.170, p=0.844\right)$.

\section{DWM Decay Classes}

Most of the volume of DWM was in advanced stages of decomposition (decay class 6 and 7, Fig. 4.6). The proportion of DWM lying on the ground $(75.1 \%)$ was higher for more decomposed DWM (Fig. 4.6). The decay class distribution of total DWM volume did not differ among stand groups (Fig. 4.7) or among treatments (Fig. 4.8).

\section{Discussion}

Small DWM contributes little to the total DWM volume in either study area; however, it is preferred over larger DWM by microarthropods (Abbott and Crossley 1982) and is therefore an important factor in the biodiversity of an ecosystem. Furthermore, small DWM is an important component of nutrient cycling because it quickly decomposes (MacMillan 


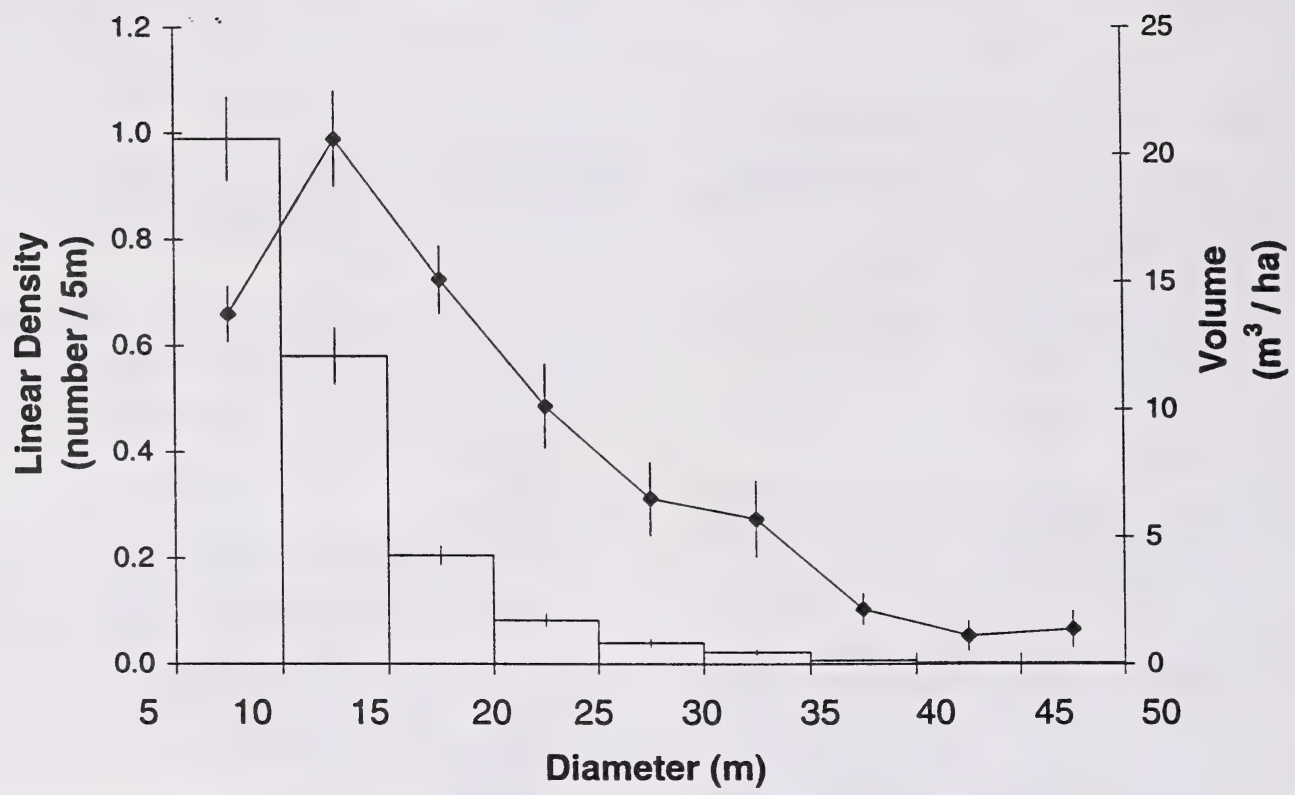

FIGURE 4.1. Size class distribution of the density (histogram) and volume (line) of DWM in the Grande Prairie study area. 
TABLE 4.4. Average diameter of large DWM $( \pm$ SE) among stand groups in both study areas. Superscripts denote homogeneous subsets as determined by Tukey's Honestly Significant Difference $(\alpha=0.05)$.

Diameter $(\mathrm{cm})$

Grande Prairie Area

Group

A

B

C

$\mathrm{D}$

$14.2 \pm 0.87^{\mathrm{a}}$

$15.0 \pm 1.39^{\mathrm{ab}}$

$16.8 \pm 0.50^{\circ}$

$15.7 \pm 0.26^{\mathrm{b}}$

Treatment 1

$15.5 \pm 0.80^{\mathrm{ab}}$

2

$16.3 \pm 0.50^{\mathrm{a}}$

$14.6 \pm 1.03^{b}$

Whitecourt Area

$\begin{array}{ll}\text { Group } & \text { A } \\ & \text { B } \\ & \text { C } \\ & \text { D }\end{array}$

Treatment
1
2
3
$15.5 \pm 0.21^{\mathrm{a}}$

$20.5 \pm 0.47^{b}$

$17.2 \pm 0.63^{\mathrm{c}}$

$17.5 \pm 1.06^{\mathrm{c}}$

$17.9 \pm 1.09$

$17.4 \pm 1.04$

$17.7 \pm 1.31$ 


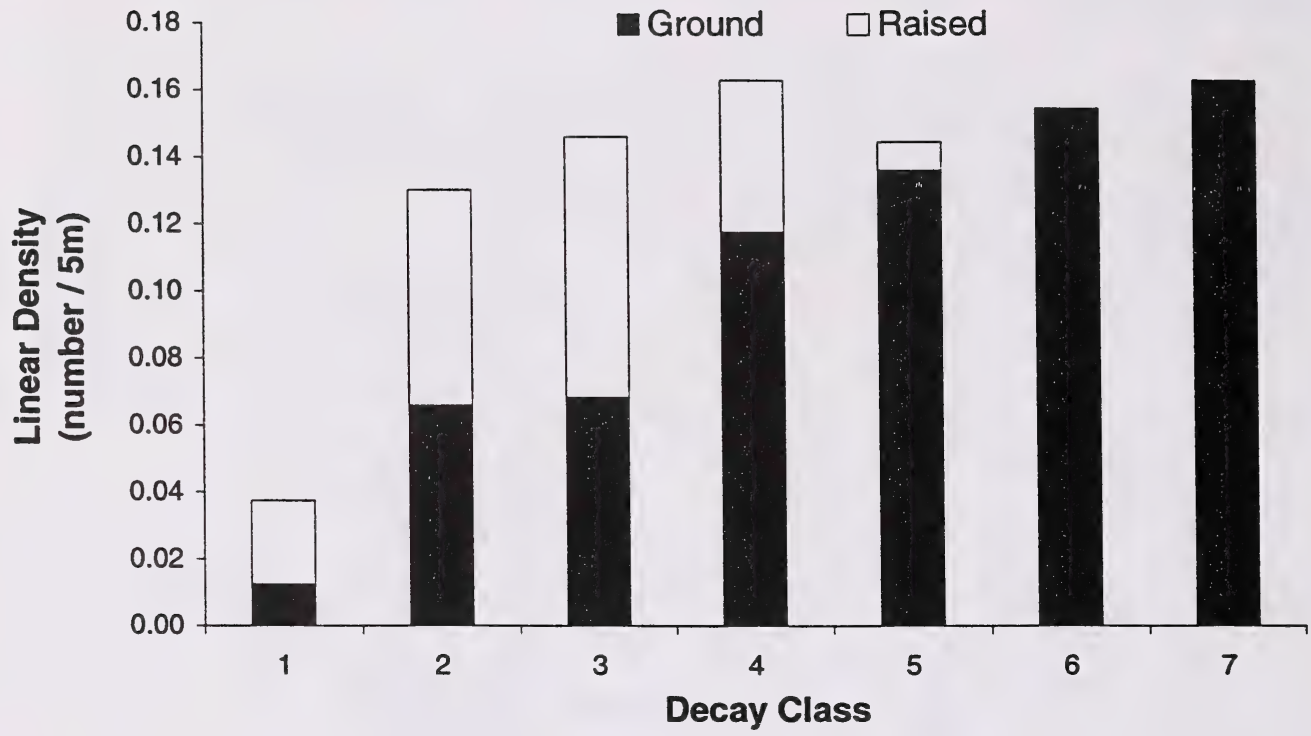

FIGURE 4.2. Average linear density of DWM in each decay class in the Grande Prairie study area distinguishing between DWM raised off the ground and DWM lying on the ground. 


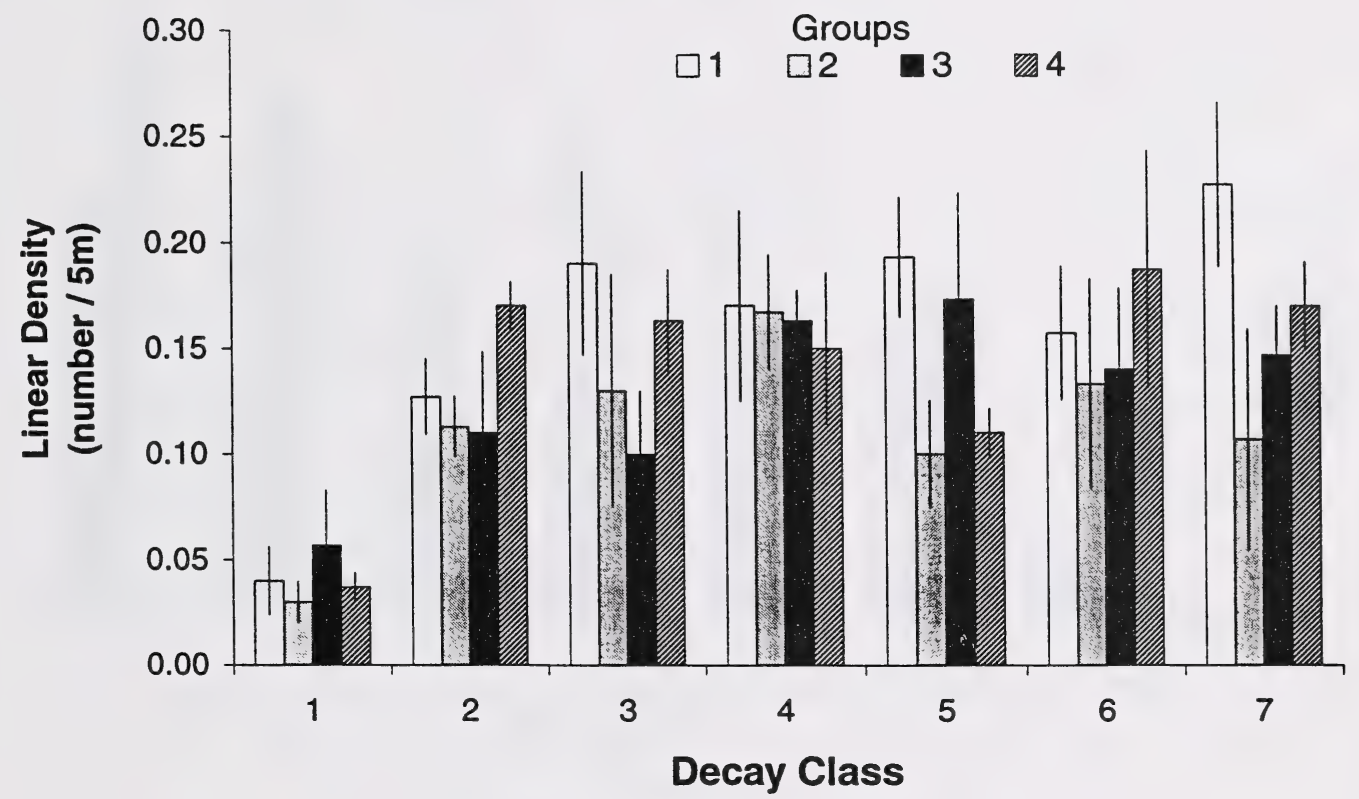

FIGURE 4.3. Average linear density ( \pm SE) of large DWM in different decay stages among stand groups in the Grande Prairie study area. 


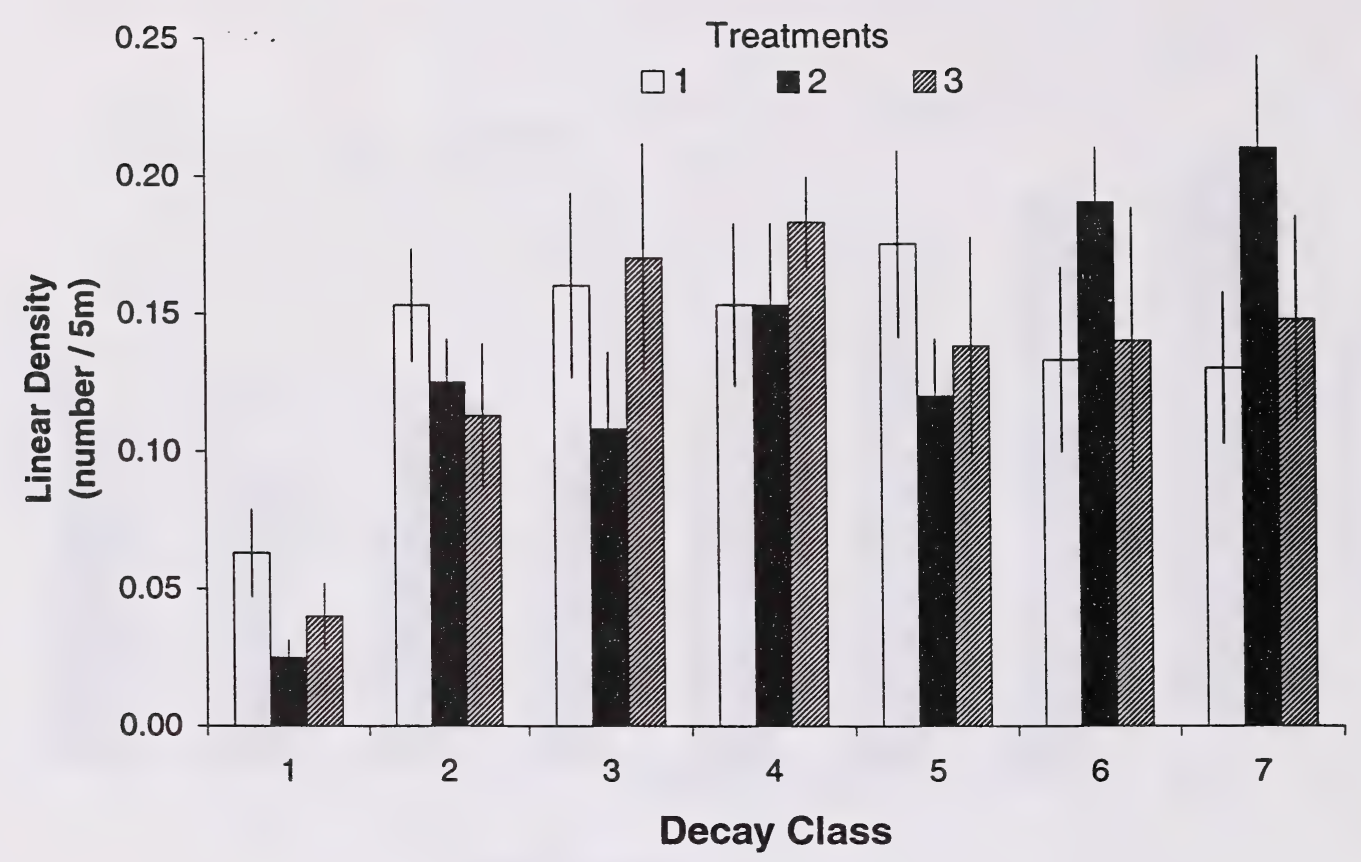

FIGURE 4.4. Average linear density $( \pm S E)$ of large DWM in different decay stages among stand treatments in the Grande Prairie study area. 


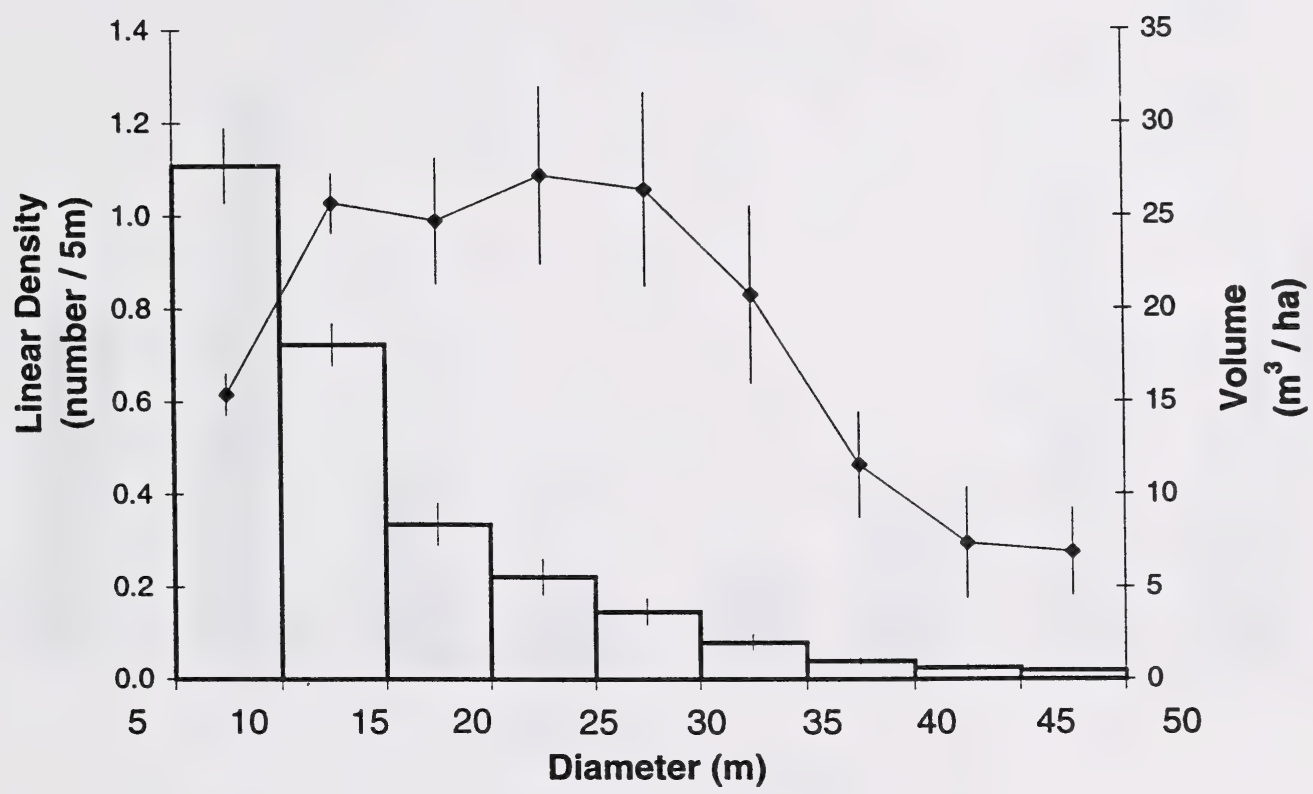

FIGURE 4.5. Size class distribution of the density (histogram) and volume (line) of DWM in the Whitecourt study area. 


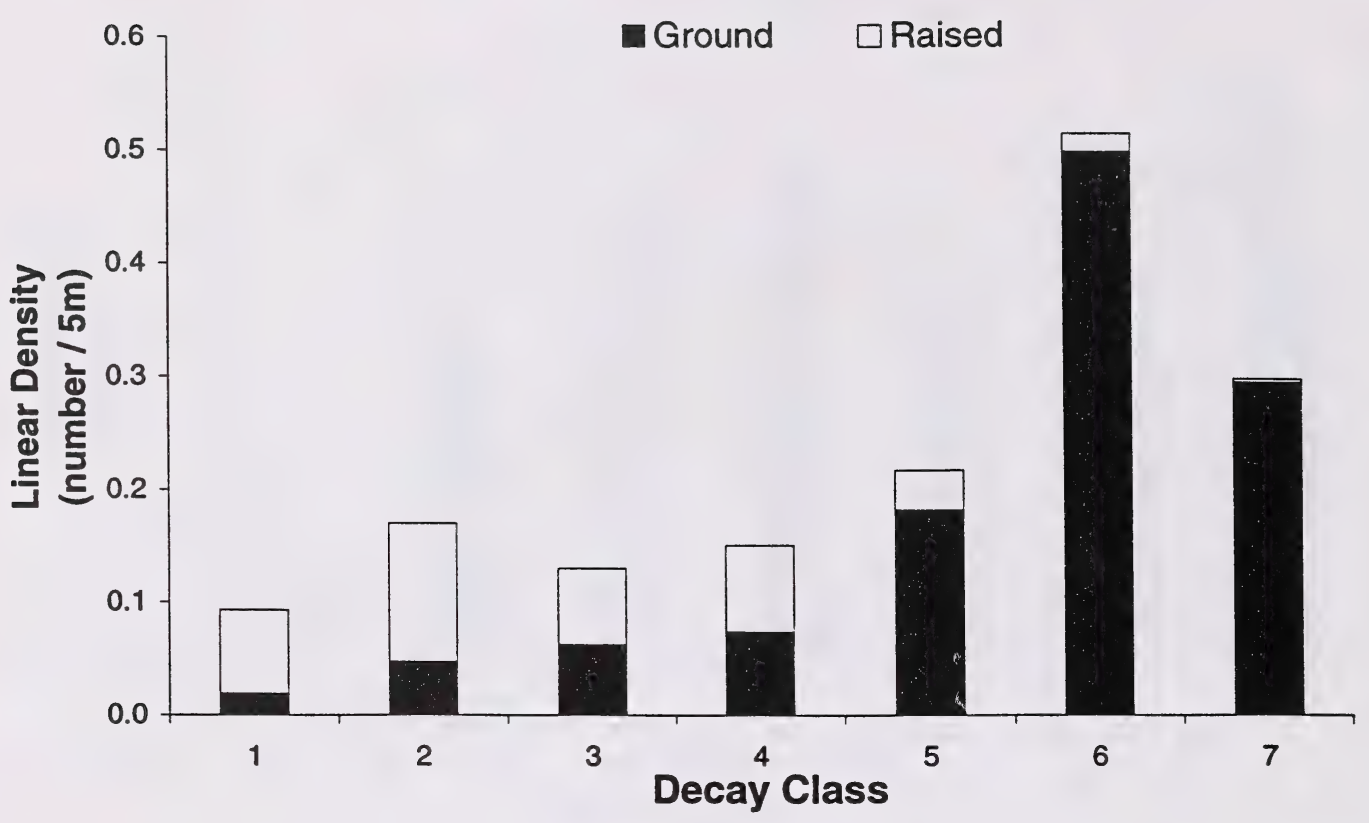

FIGURE 4.6. Decay class distribution of the density of DWM in the Whitecourt study area distinguishing between DWM raised off the ground and DWM lying on the ground. 


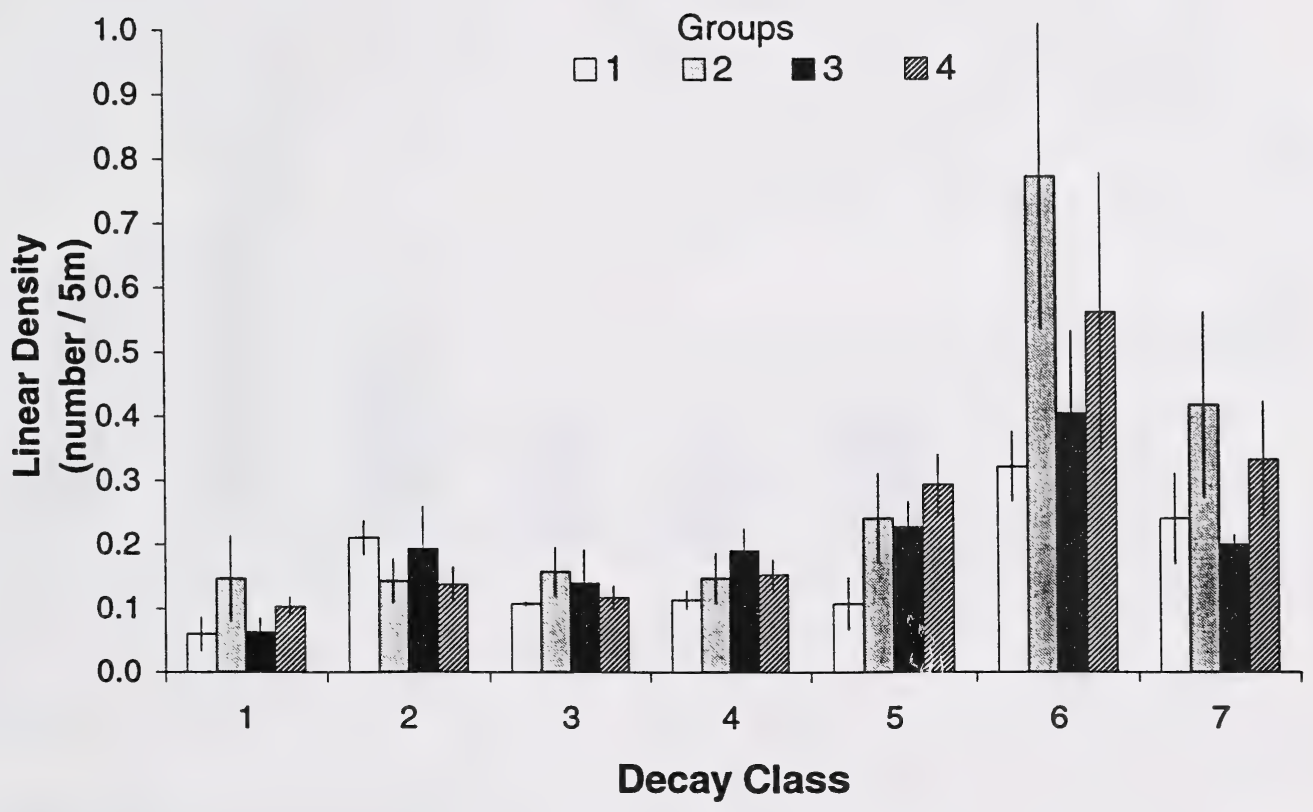

FIGURE 4.7. Average linear density ( \pm SE) of large DWM in different decay stages among stand groups in the Whitecourt study area. 


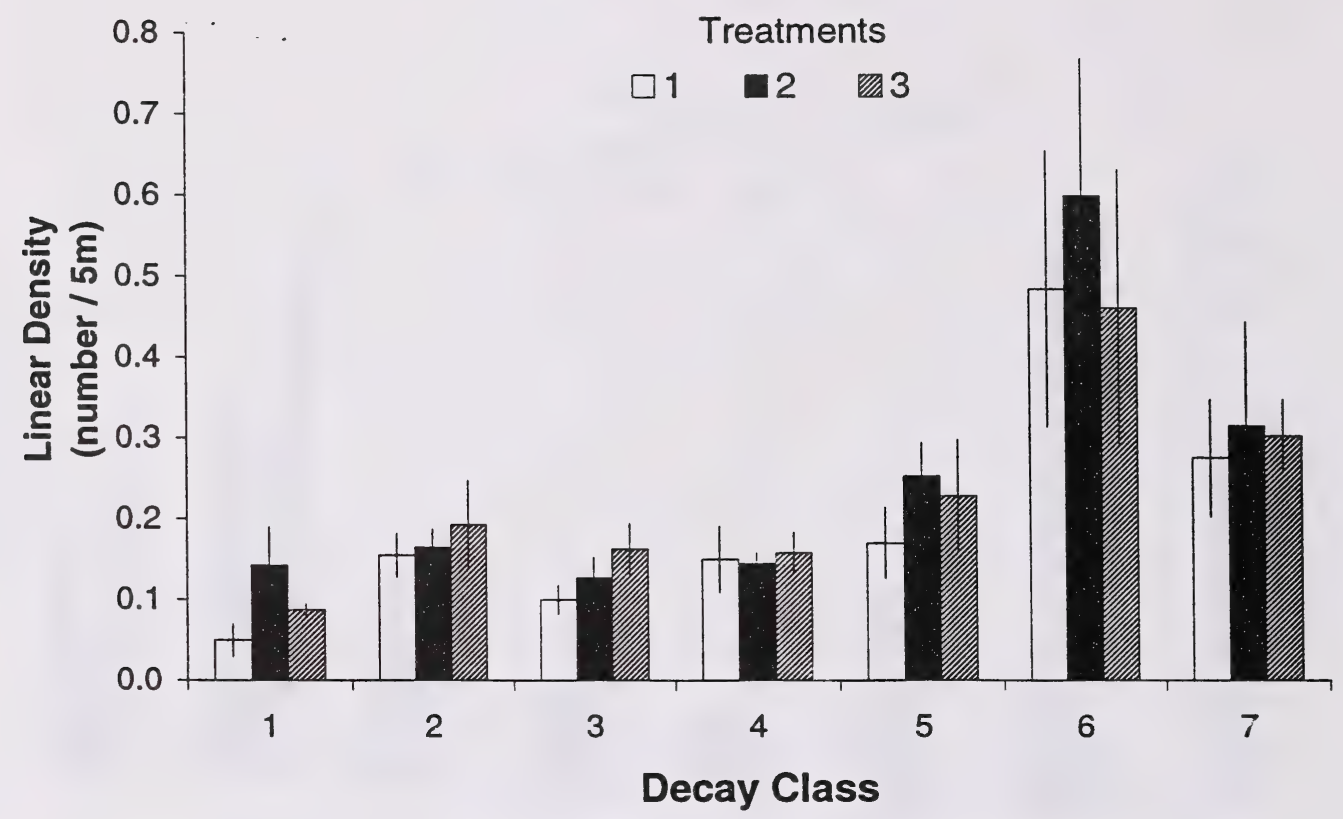

FIGURE 4.8. Average linear density ( \pm SE) of large DWM in different decay classes among stand treatments in the Whitecourt study area. 
1981, Abbott and Crossley 1982) returning nutrients to the soil.

The Grande Prairie study area had higher density, lower volume, and smaller sizes of DWM than other areas of $>120$ years-old aspendominated forest in Alberta (Lee et al. 1995, 1997). Densities, volumes and sizes of pine/spruce DWM could not be found in the literature.

The clumped spatial distribution of DWM within stands in both study areas suggests that leaving residual material in patches may be closer to natural spatial distributions (Lee et al. $1995,1997)$ than if DWM was retained in a regular pattern. The clumped distribution of DWM in the Whitecourt study area is probably due to the nature of tree mortality; windfall usually causes clumped distributions of DWM (Harmon et al. 1986). In both study areas, DWM was more abundant near wet areas possibly because the roots of trees in wet areas facilitate windfall, especially for coniferous species (Harmon et al. 1986).

The decay class distribution of DWM in the Grande Prairie study area was very similar to that found in $>120$ year-old aspen dominated forests in other areas of Alberta (Crites and Dale 1995, in press; Lee et al. 1995, 1997). The onset of bark loss in year 1 for aspen logs (Miller 1983) results in DWM passing through decay class 1 quickly. Decay class distributions of DWM from pine/spruce dominated forest could not be found in the literature.

The difference in decay class distributions of DWM between the Grande Prairie and Whitecourt study areas suggests that aspen, pine, and spruce DWM may have different residence times within each decay class. The shady, cool understory of the pine/spruce forest promotes moss cover $(30.61 \% \pm 1.28 \mathrm{SE}$, Chapter 5) compared to the sunny, dry understory of aspen forest $(3.27 \% \pm 0.31$ SE, Chapter 5; Söderström 1988a). In the pine/spruce forest, moss quickly covered intact and sound DWM therefore most DWM was classified as decay class 6 or 7. On the other hand, plants may colonized DWM at similar times in both study areas but the decomposition rate of DWM following plant colonization (stages 6 -7) may be slower for pine/spruce DWM than aspen DWM. The time required for logs to lose half their wood density varies greatly between soft- and hardwoods: 57 years for pine (Pinus contorta, Fahey 1983), 63 years for balsam fir (Lambert et al. 1980), but only 10-14 years for aspen (Gosz 1080, Miller 1983, reviewed by Harmon et al. 1986). Hardwoods decompose faster than softwoods (MacMillan 1981, Harmon 1982) due to different wood structure and chemical composition (Wilcox 1973).

A second explanation for differences in distributions of DWM between the study areas is that there may have been a large, synchronized, mortality of pine and spruce trees in the Whitecourt study area within the time required for complete decomposition of DWM. Balsam fir logs can retain half of their volume for 100 years (Lambert et al. 1980). This cohort of DWM may be the killed trees from the last fire 105 years ago (unpublished data). If this is true, DWM dynamics not reached equilibrium before the area was harvested. Within a few decades the DWM in decay classes 6 and 7 may become indistinguishable, and the density and size distribution of DWM in the Whitecourt study area may be similar to estimates from the Grande Prairie study area which is probably at equilibrium.

Natural dynamics in old forests provide constant inputs of DWM resulting in a relatively even distribution of size classes and decay stages (Harmon et al. 1986; Söderström 1988b; Lee et al. 1995, 1997; Crites and Dale 1995, in press). On the other hand, managed stands have irregular inputs of DWM and an uneven distribution of DWM decay stages (Söderström 1988b). Clearcutting initially results in lower density and volume of large DWM (Lesica et al. 1991; Lee et al. 1995, 1997) and a pulse of undecayed small branches and twigs from felled and delimbed trees (Abbott and Crossley 1982; Crites and Dale 1995, in press). At mid-rotation the small residual material is in advanced stages of decomposition with low input of trees from self-thinning and death of residual trees (Lee et al 1995, 1997). In old age, large senescing trees will begin to consistently input DWM with even decay class and size distributions (Lee et al. 
1995, 1997). Pulses of DWM may result in temporal heterogeneity in the abundance of species dependent on specific decay stages such as epixylics (Söderström 1988a,b; Lesica et al. 1991) and of species dependent on specific sizes of DWM such as microarthropods (Abbott and Crossley 1982, Söderström 1988a).

Many species of bryophytes, lichens, and some vascular plants are dependent on specific stages of DWM decomposition (Muhle and LeBlanc 1975; Crites and Dale 1995, in press).

Söderström (1988b) suggested three requirements to maintain pre-harvest compositions of species dependent on DWM, such as lichens and bryophytes: DWM must be present in all stages of decomposition, DWM must have an even spatial distribution, and areas with DWM must be protected from drying out. A uniform distribution of DWM will allow DWM-dependent species to disperse into harvesied areas (Lesica et al. 1991). Many of the rare lichens and bryophytes have limited dispersal capabilities and may require residual patches of DWM to act as dispersal centers (Söderström 1988). These same species need shaded areas with dependable humidity (Muhle and LeBlanc 1975, Larson 1984, Söderström 1988a, Lesica et al. 1991, Gustafsson et al. 1992).

The smaller, more abundant residual patches created in treatment 1 of this study will result in a more even spatial distribution of DWM and may facilitate the dispersal of DWM-dependent species into harvested areas. However, the smaller patches may have more variability in evaporation rates which suppresses nonvascular plants and DWM decomposition (Gustafsson et al. 1992, Söderström 1988a). Stands in treatments 2 and 3 with larger and wider spaced residual tree patches may retain more interiorforest habitat with a more natural humidity, temperature, shade, and natural decomposition rates of DWM. Natural decomposition rates may maintain temporally homogenous compositions of DWM-dependent species. On the other hand, the dispersal of species into the harvested areas may be restricted due to wider spaced patches of DWM.
Initially, an environment that allows DWMdependent species to survive will be more important than an environment that facilitates dispersal. The ability of DWM-dependent species to disperse will become important once the canopy is established and the understory of harvested areas are buffered from sunlight and desiccation. Thus, the influence of DWM dispersion on biodiversity may shift from patch size to inter-patch distance as the harvested areas regenerate.

Pre-harvest characteristics of DWM provide a benchmark to which harvested areas can be compared. Stand groups were successful in accounting for pre-harvest variance of DWM, whereas there were few differences prior to harvest among randomly assigned treatments. Thus, any post-harvest differences in DWM among treatments may be attributed to treatment effects.

\section{Future Research}

Post-harvest characteristics of DWM will be surveyed in 1998 using the same methods as in 1997 with additional sampling to estimate DWM characteristics in residual tree patches. Additional transects will be sampled at random directions through the middle of residual tree patches for a total of $80 \mathrm{~m}$ (87.5 yd.) per stand.

If time permits, the wood density of large DWM in each decay class will be sampled so that DWM biomass can be calculated from volume estimates. Biomass is most frequently presented in the literature (Gosz 1980, Pastor and Bockheim 1984, Harmon et al. 1986). For each decay class, cross-sections ('cookies') of ten logs will be measured for volume (diameter and thickness of section), weighed, oven dried, and then re-weighed. This will also provide estimates of moisture content and biomass loss which in turn may affect bryophytes, lichens and other plants (Harmon et al. 1986).

In the winter of 1998-1999, the density, volume, spatial distribution, and decomposition of postharvest DWM will be compared among treatment. 


\section{Literature cited}

Abbott, D.T. and D.A. Jr. Crossley. 1982. Woody litter decomposition following clearcutting. Ecology 63: 35-42.

Crites, S. and M. Dale. 1995. Relationships between nonvascular species and stand age and stand structure in aspen mixedwood forests in Alberta. In Relationships between stand age, stand structure, and biodiversity in aspen mixedwood forests in Alberta. Edited by J.B. Stelfox. Jointly published by Alberta Environmental Center (AECV95-R1), Vegreville, AB, and Canadian Forest Service (Project No. 0001A), Edmonton, AB. pp. 6379.

Crites, S. and M.R.T. Dale. In Press. Diversity and abundance of bryophytes, lichens, and fungi in relation to woody substrate and successional stage in aspen mixedwood boreal forests.

Gosz, J.R. 1980. Biomass distribution and production budget for a nonaggrading forest ecosystem. Ecology 61: 507-514.

Gustafsson, L., A. Fiskesjö, T. Hallingbäck, T. Ingelög, and B. Pettersson. 1992. Semi-natural deciduous broad-leaved woods in southern Sweden - Habitat factors of importance to some bryophyte species. Biological Conservation 59: 175-181.

Harmon, M. E. 1982. Decomposition of standing dead trees in the southern Appalachian Mountains. Oecologia 52: 214215.

Harmon, M.E., J.F. Franklin, F.J. Swanson, P. Sollins, S.V. Gregory, J.D. Lattin, N.H. Anderson, S.P. Cline, N.G. Aumen, J. R. Sedell, G.W. Lienkaemper, K. Cromack, Jr., and K.W. Cummins. 1986. Ecology of coarse woody debris in temperate ecosystems. Advances in Ecological Research 15: 133302.

Lambert, R.L., G.E. Lang, and W.A. Reiners. 1980. Loss of mass and chemical change in decaying boles of a subalpine balsam fir forest. Ecology 61: 1460-1473.
Larson, D.W. 1984. Habitat overlap/niche segregation in two Umbilicaria lichens: a possible mechanism. Oecologia 62: 118-125.

Lee, P.C., S. Crites, M. Nietfeld, H. Van Nguyen, and J.B. Stelfox. 1995. Changes in Snags and down woody material characteristics in a chronosequence of aspen mixedwood forests in Alberta. In Relationships between stand age, stand structure, and biodiversity in aspen mixedwood forests in Alberta. Edited by J. B. Stelfox. Jointly published by Alberta Environmental Center (AECV95-R1), Vegreville, AB, and Canadian Forest Service (Project No. 0001A), Edmonton, AB. pp. 4961.

Lee, P.C., S. Crites, M. Nietfeld, H. Van Nguyen, and J.B. Stelfox. 1997. Characteristics and origins of deadwood material in aspen-dominated boreal forests. Ecological Applications 7: 691-701.

Lesica, P., B. McCune, S.V. Cooper, and W.S. Hong. 1991. Differences in lichen and bryophyte communities between old-growth and managed second-growth forests in the Swan Valley, Montana. Canadian Journal of Botany 69: 1745-1755.

MacMillan, P.C. 1981. Log decomposition in Donaldson's Woods, Spring Mill State Park, Indiana. The American Midland Naturalist 106: 335-344.

McCullough, H.A. 1948. Plant succession on fallen logs in a virgin spruce-fir forest. Ecology 29: 508-513.

Miller, W. 1983. Decomposition rates of aspen bole and branch litter. Forest Science 29: 351356.

Muhle, H. and F. LeBlanc. 1975. Bryophyte and lichen succession on decaying logs. I.

Analysis along an evaporational gradient in eastern Canada. Journal of Hattori Botanical Laboratory 39: 1-33.

Pastor, J. and J.G. Bockheim. 1984. Distribution and cycling of nutrients in an apsen-mixed-hardwood-spodosol ecosystem in northern Wisconsin. Ecology 65: 339-353. 
Söderström, L. 1988a. Sequence of bryophytes and lichens in relation to substrate variables of decaying coniferous wood in northern Sweden. Nordic Journal of Botany 8: 89-97.

Söderström, L. 1988b. The occurrence of epixylic bryophyte and lichen species in an old natural and a managed forest stand in northeast Sweden. Biological Conservation 45: 169-178.

SPSS Inc. 1997. SPSS 7.5.1 for Windows.

Thompson, J.N. 1980. Treefalls and colonization patterns of temperate forest herbs. The American Midland Naturalist 104: 176-184.

Van Wagner, C.E. 1968. The line intersect method in forest fuel sampling. Forest Science 14: $20-26$.

Wilcox, W.W. 1973. Degradation in relation to wood structure. In Wood Deterioration and its Prevention by Preservative Treatments. Edited by D.D. Nicholas. Syracuse University Press, New York. pp. 107-148.

Zar, J. H. 1984. Biostatistical Analysis, $2^{\text {nd }}$ edition. Prentice Hall, New Jersey. 


\section{CHAPTER 5. A SUMMARY OF UNDERSTORY VEGETATION IN THE BOREAL FOREST PRIOR TO HARVEST.}

\section{Christine Gray}

\section{Introduction}

Due to funding constraints, only preliminary surveys were conducted for the understory vegetation during the 1997 field season. This report is a summary of that data. More detailed data collection, summary, and analyses will be conducted during 1999/2000.

\section{Methods}

In both study areas, vegetation was sampled at 5 out of the 10 possible 1 ha ( 2.47 acre) sites (every second site) within each stand. Each 1 ha site was divided into four equal quadrants (Fig 2.3). Two herb plots [0.5 x $0.5 \mathrm{~m}(1.6 \times 1.6 \mathrm{ft}$. $)]$ were systematically placed in all four quadrants ( 8 herb plots per site and 40 herb plots per stand).

For sampling purposes, vegetation was divided into two height strata. The herb stratum included all herbs regardless of height, and trees and shrubs that were $<0.5 \mathrm{~m}(<1.6 \mathrm{ft}$.) in height. The shrub stratum included all shrubs $\geq 0.5 \mathrm{~m}$ $(\geq 1.6 \mathrm{ft}$.) in height, and trees that were between 0.5 and $1.5 \mathrm{~m}(1.6-4.9 \mathrm{ft}$.) tall. Shrubs were divided into height classes of $\mathbf{0}=0.5-1.39 \mathrm{~m}$ (1.6-4.6 ft.); 1 = 1.4-2.9 m (4.7-9.5 ft.); 2 = 3.0$4.9 \mathrm{~m}(9.6-16.1 \mathrm{ft}$ ) ; $3=5.0-9.9 \mathrm{~m}$ (16.2-32.5 $\mathrm{ft}.) ; 4=10.0-19.9 \mathrm{~m}(32.6-65.6 \mathrm{ft}$.); and $5=$ $\geq 20.0 \mathrm{~m}$ ( $\geq 65.6 \mathrm{ft}$.). In the Grande Prairie study area one shrub plot [2.0 $2.0 \mathrm{~m}(6.6 \times 6.6 \mathrm{ft}$.) ] was systematically placed in two of the four randomly selected quadrants ( 2 shrub plots per site and 10 shrub plots per stand). In the Whitecourt study area a shrub plot was placed in all four quadrants (4 shrub plots per site and 20 shrub plots per stand). Herb plots were nested within shrub plots. Sampling was conducted from mid June through mid August 1997.

Percent of ground surface cover was visually estimated for litter, wood, moss, lichen, and grass, and percent of ground surface covered by a vertical projection of leaves and stems was estimated for individual species of herbs, shrubs, and trees. In the Whitecourt study area percent of the ground surface cover by individual moss species was recorded as they were the dominant ground cover. Grasses and lichens were not identified to species at either study area. Unknown species were pressed and later identified at the University of Alberta herbarium. Nomenclature follows Moss (1992) for vascular species. For nonvascular species, nomenclature follows Vitt et al. (1988).

\section{Results}

\section{Grande Prairie Study Area}

Eighty-three species were found in the herbaceous strata, of which 55 were herbs, 25 were shrubs, and three were tree species (Table 5.1). Of the 25 shrub species found in the herb strata, 9 were not found in the shrub strata. Within the herb strata, much of the ground was covered by litter ( $43 \%$ cover) although herbs and shrubs were also abundant (39\% and $18 \%$ cover respectively). Percent cover of grasses, mosses, and lichen were much lower (Table 5.1). Bunchberry was the most abundant herb ( $6 \%$ cover), with Prickly rose and Bracted honeysuckle the most abundant shrubs (5\% cover for each) in the herb strata. Trees had low percent cover in both the herb and shrub strata (Table 5.1).

The shrub strata contained 21 species, of which 18 were shrubs and 3 were tree species (Table 5.1). Of these, River alder and Common Labrador tea were unique to the shrub stratum. The most abundant shrubs in the shrub stratum were Bracted honeysuckle ( $6 \%$ cover), Canadian buffaloberry ( $5 \%$ cover), and Prickly rose ( $5 \%$ cover). Trembling aspen was the most abundant tree species ( $1 \%$ cover) in the shrub stratum. 
TABLE 5.1. Mean percent cover $( \pm S E)$ of understory vegetation for the Grande Prairie study area during 1997 . Individual species are grouped by strata level and family.

\begin{tabular}{|c|c|c|c|}
\hline Common Name & Species Name & $\begin{array}{l}\text { Species } \\
\text { Code }\end{array}$ & $\begin{array}{l}\text { Mean } \\
\text { Percent Cover }\end{array}$ \\
\hline Litter Total Cover & & & $43.17 \pm 0.92$ \\
\hline Wood Total Cover & & & $5.31 \pm 0.45$ \\
\hline Lichen Total Cover & & & $0.01 \pm 0.00$ \\
\hline Moss Total Cover & & & $3.27 \pm 0.31$ \\
\hline Grass Total Cover & & & $4.81 \pm 0.26$ \\
\hline $\begin{array}{l}\text { Herb Total Cover } \\
\text { Lycopodiaciaceae }\end{array}$ & & & $38.92 \pm 1.01$ \\
\hline Stiff club-moss & Lycopodium annotinum & LYC ANN & $0.06 \pm 0.02$ \\
\hline $\begin{array}{l}\text { Ground-cedar } \\
\text { Equisetaceae }\end{array}$ & Lycopodium complanatum & LYC COM & $0.04 \pm 0.04$ \\
\hline Common horsetail & Equisetum arvense & EQU ARV & $0.23 \pm 0.04$ \\
\hline $\begin{array}{l}\text { Woodland horsetail } \\
\text { Polypodiaceae }\end{array}$ & Equisetum sylvaticum & EQU SYL & $0.04 \pm 0.01$ \\
\hline Lady fern & Athyrium filix-femina & ATH FIL & $0.01 \pm 0.01$ \\
\hline $\begin{array}{l}\text { Oak fern } \\
\text { unknown fern }\end{array}$ & Gymnocarpium dryopteris & $\begin{array}{l}\text { GYM DRY } \\
\text { UNK FER }\end{array}$ & $\begin{array}{l}0.01 \pm 0.01 \\
0.08 \pm 0.08^{1}\end{array}$ \\
\hline Liliaceae & & & \\
\hline Fairybells & Disporum trachycarpum & DIS TRA & $0.01 \pm 0.01$ \\
\hline Wild lily-of-the-valley & Maianthemum canadense & MAI CAN & $0.67 \pm 0.08$ \\
\hline Star-flowered false solomon's-seal & Smilacina stellata & SMI STE & $0.04 \pm 0.03$ \\
\hline Three-leaved false solomon's-seal & Smilacina trifolia & SMI TRI & $0.02 \pm 0.01$ \\
\hline $\begin{array}{l}\text { unknown lily } \\
\text { Orchidaceae }\end{array}$ & Smilacina spp. & SMI SPP & $0.02 \pm 0.02$ \\
\hline Rattlesnake-plantain & Goodyera oblongifolia & GOO OBL & $0.01 \pm 0.01$ \\
\hline $\begin{array}{l}\text { Blunt-leaved bog-orchid } \\
\text { Ranunculaceae }\end{array}$ & Habenaria obtusata & НАВ ОВТ & $0.01 \pm 0.01$ \\
\hline Red and white baneberry & Actaea rubra & ACT RUB & $0.32 \pm 0.06$ \\
\hline $\begin{array}{l}\text { Veiny meadow rue } \\
\text { Saxifragaceae }\end{array}$ & Thalictrum venulosum & THA VEN & $0.01 \pm 0.01$ \\
\hline $\begin{array}{l}\text { Bishop's cap : } \\
\text { Rosaceae }\end{array}$ & Mitella nuda & MIT NUD & $0.78 \pm 0.08$ \\
\hline Wild strawberry & Fragaria virginiana & FRA VIR & $2.47 \pm 0.13$ \\
\hline $\begin{array}{l}\text { Dewberry } \\
\text { Leguminosae }\end{array}$ & Rubus pubescens & RUB PUB & $2.17 \pm 0.15$ \\
\hline Creamy peavine & Lathyrus ochroleucus & LAT OCH & $3.01 \pm 0.18$ \\
\hline $\begin{array}{l}\text { American vetch } \\
\text { Violaceae }\end{array}$ & Vicia americana & VIC AME & $1.20 \pm 0.11$ \\
\hline Canada violet & Viola canadensis & VIO CAN & $0.26 \pm 0.07$ \\
\hline $\begin{array}{l}\text { Kidney-leaved violet } \\
\text { Onagraceae }\end{array}$ & Viola renifolia & VIO REN & $0.53 \pm 0.07$ \\
\hline Fireweed & Epilobium angustifolium & EPI ANG & $2.65 \pm 0.19$ \\
\hline
\end{tabular}

${ }^{1}$ Sum of two unidentified fern species. 
TABLE 5.1 cont.

\begin{tabular}{|c|c|c|c|}
\hline Common Name & Species Name & $\begin{array}{l}\text { Species } \\
\text { Code }\end{array}$ & $\begin{array}{l}\text { Mean } \\
\text { Percent Cover }\end{array}$ \\
\hline \multicolumn{4}{|l|}{ Araliaceae } \\
\hline $\begin{array}{l}\text { Wild sarsaparilla } \\
\text { Umbelliferae }\end{array}$ & Aralia nudicaulis & ARA NUD & $1.83 \pm 0.25$ \\
\hline $\begin{array}{l}\text { Cow-parsnip } \\
\text { Cornaceae }\end{array}$ & Heracleum lanatum & HER LAN & $0.23 \pm 0.09$ \\
\hline $\begin{array}{l}\text { Bunchberry } \\
\text { Pyrolaceae }\end{array}$ & Cornus canadensis & COR CAN & $6.11 \pm 0.32$ \\
\hline One-sided wintergreen & Orthilia secunda & ORT SEC & $0.04 \pm 0.03$ \\
\hline Common pink wintergreen & Pyrola asarifolia & PYR ASA & $0.94 \pm 0.10$ \\
\hline $\begin{array}{l}\text { Northern starflower } \\
\text { Gentianaceae }\end{array}$ & Trientalis borealis & TRI BOR & $0.02 \pm 0.01$ \\
\hline $\begin{array}{l}\text { Spurred gentian } \\
\text { Boraginaceae }\end{array}$ & Halenia deflexa & HAL DEF & $0.06 \pm 0.02$ \\
\hline $\begin{array}{l}\text { Tall lungwort } \\
\text { Labiatae }\end{array}$ & Mertensia paniculata & MER PAN & $1.61 \pm 0.17$ \\
\hline $\begin{array}{l}\text { Marsh skullcap } \\
\text { Scrophulariaceae }\end{array}$ & Scutellaria galericulata & SCU GAL & $0.01 \pm 0.01$ \\
\hline $\begin{array}{l}\text { Common red paintbrush } \\
\text { Rubiaceae }\end{array}$ & Castilleja miniata & CAS MIN & $0.52 \pm 0.09$ \\
\hline Northern bedstraw & Galium boreale & GAL BOR & $1.36 \pm 0.09$ \\
\hline $\begin{array}{l}\text { Sweet-scented bedstraw } \\
\text { Caprifoliaceae }\end{array}$ & Galium triflorum & GAL TRI & $0.06 \pm 0.01$ \\
\hline $\begin{array}{l}\text { Twinflower } \\
\text { Compositae }\end{array}$ & Linnaea borealis & LIN BOR & $2.89 \pm 0.17$ \\
\hline Common yarrow & Achillia millefolium & ACH MIL & $0.26 \pm 0.04$ \\
\hline Heart-leaved arnica & Amica cordifolia & ARN COR & $0.36 \pm 0.07$ \\
\hline Lindley's aster & Aster ciliolatus & AST CIL & $0.90 \pm 0.13$ \\
\hline Showy aster & Aster conspicuus & AST CON & $3.37 \pm 0.29$ \\
\hline Purple-stemmed aster & Aster puniceus & AST PUN & $0.03 \pm 0.02$ \\
\hline Narrow-leaved hawkweed & Hieracium umbellatum & HIE UMB & $0.96 \pm 0.17$ \\
\hline Palmate-leaved coltsfoot & Petasites palmatus & PET PAL & $2.38 \pm 0.16$ \\
\hline Arrow-leaved coltsfoot & Petasites sagittatus & PET SAG & $0.14 \pm 0.08$ \\
\hline Canadian butterweed & Senecio pauperculus & SEN PAU & $0.01 \pm 0.01$ \\
\hline Canada goldenrod & Solidago canadensis & SOL CAN & $0.09 \pm 0.04$ \\
\hline Late goldenrod - & Solidago gigantea & SOL GIG & $0.03 \pm 0.02$ \\
\hline Common dandelion & Taraxacum officinale & TAR OFF & $0.01 \pm 0.01$ \\
\hline unknowns & & UNK & $0.09 \pm 0.07^{2}$ \\
\hline $\begin{array}{l}\text { Shrub Total Cover }(<0.5 \mathrm{~m}) \\
\text { Salicaceae }\end{array}$ & & & $18.21 \pm 0.55$ \\
\hline $\begin{array}{l}\text { willow } \\
\text { Betulaceae }\end{array}$ & Salix spp. & SAL SPP & $0.10 \pm 0.04$ \\
\hline Green alder & Alnus crispa & ALN CRI & $0.03 \pm 0.02$ \\
\hline $\begin{array}{l}\text { Beaked hazelnut } \\
\text { Grossulariaceae }\end{array}$ & Corylus cornuta & COR COR & $0.07 \pm 0.05$ \\
\hline Skunk currant & Ribes glandulosum & RIB GLA & $0.01 \pm 0.01$ \\
\hline
\end{tabular}

${ }^{2}$ Sum of five unidentified herb species. 
TABLE 5.1 cont.

\begin{tabular}{|c|c|c|c|}
\hline Common Name & Species Name & $\begin{array}{l}\text { Species } \\
\text { Code }\end{array}$ & $\begin{array}{l}\text { Mean } \\
\text { Percent Cover }\end{array}$ \\
\hline Northern black currant & Ribes hudsonianum & RIB HUD & $0.06 \pm 0.03$ \\
\hline Black gooseberry & Ribes lacustre & RIB LAC & $0.04 \pm 0.02$ \\
\hline Northern gooseberry & Ribes oxyacanthoides & RIB OXY & $0.16 \pm 0.03$ \\
\hline Wild red currant & Ribes triste & RIB TRI & $0.36 \pm 0.08$ \\
\hline unknown currant & Ribes spp & RIB SPP & $0.10 \pm 0.04$ \\
\hline Rosaceae & & & \\
\hline Saskatoon & Amelanchier alnifolia & AME ALN & $0.29 \pm 0.08$ \\
\hline Pin cherry & Prunus pensylvanica & PRU PEN & $0.03 \pm 0.02$ \\
\hline Choke cherry & Prunus virginiana & PRU VIR & $0.01 \pm 0.01$ \\
\hline Prickly rose & Rosa acicularis & ROS ACI & $5.33 \pm 0.24$ \\
\hline Wild red raspberry & Rubus idaeus & RUB IDA & $0.70 \pm 0.10$ \\
\hline $\begin{array}{l}\text { Narrow-leaved meadowsweet } \\
\text { Elaegnaceae }\end{array}$ & Spiraea alba & SPI BET & $1.09 \pm 0.13$ \\
\hline $\begin{array}{l}\text { Canada buffaloberry } \\
\text { Cornaceae }\end{array}$ & Shepherdia canadensis & SHE CAN & $0.62 \pm 0.09$ \\
\hline $\begin{array}{l}\text { Red-osier dogwood } \\
\text { Ericaceae }\end{array}$ & Cornus stolonifera & COR STO & $0.12 \pm 0.05$ \\
\hline Common bearberry & Arctostaphylos uva-ursi & ARC UVA & $0.01 \pm 0.01$ \\
\hline Common labrador tea & Ledum groenlandicum & LED GRO & $0.05 \pm 0.03$ \\
\hline Velvet-leaved blueberry & Vaccinium myrtilloides & VAC MYR & $0.78 \pm 0.14$ \\
\hline $\begin{array}{l}\text { Bog cranberry } \\
\text { Caprifoliaceae }\end{array}$ & Vaccinium vitis-idaea & VAC VIT & $0.04 \pm 0.02$ \\
\hline Twining honeysuckle & Lonicera dioica & LON DIO & $0.28 \pm 0.06$ \\
\hline Bracted honeysuckle & Lonicera involucrata & LON INV & $5.22 \pm 0.36$ \\
\hline Common snowberry & Symphoricarpos albus & SYM ALB & $0.04 \pm 0.02$ \\
\hline Low bush-cranberry & Viburnum edule & VIB EDU & $2.67 \pm 0.29$ \\
\hline $\begin{array}{l}\text { Shrub Total Cover }(>0.5 \mathrm{~m}) \\
\quad \text { Salicaceae }\end{array}$ & & & $29.36 \pm 1.95$ \\
\hline $\begin{array}{l}\text { willow } \\
\text { Betulaceae }\end{array}$ & Salix spp. & SAL SPP & $3.48 \pm 0.51$ \\
\hline Green alder & Alnus crispa & ALN CRI & $1.64 \pm 0.62$ \\
\hline River alder & Alnus tenuifolia & ALN TEN & $1.43 \pm 0.83$ \\
\hline $\begin{array}{l}\text { Beaked hazelnut } \\
\text { Grossulariaceae }\end{array}$ & Corylus cornuta & COR COR & $0.18 \pm 0.13$ \\
\hline $\begin{array}{l}\text { Northern goosèberry } \\
\text { unknown currant } \\
\text { Rosaceae }\end{array}$ & $\begin{array}{l}\text { Ribes oxyacanthoides } \\
\text { Ribes spp. }\end{array}$ & $\begin{array}{l}\text { RIB OXY } \\
\text { RIB SPP }\end{array}$ & $\begin{array}{l}0.07 \pm 0.04 \\
0.02 \pm 0.01\end{array}$ \\
\hline Saskatoon & Amelanchier alnifolia & AME ALN & $0.94 \pm 0.27$ \\
\hline Pin cherry & Prunus pensylvanica & PRU PEN & $0.41 \pm 0.16$ \\
\hline unknown cherry & Prunus spp. & PRU SPP & $0.01 \pm 0.01$ \\
\hline Choke cherry & Prunus virginiana & PRU VIR & $0.02 \pm 0.01$ \\
\hline Prickly rose & Rosa acicularis & ROS ACI & $5.02 \pm 0.58$ \\
\hline $\begin{array}{l}\text { Wild red raspberry } \\
\text { Elaegnaceae }\end{array}$ & Rubus idaeus & RUB IDA & $0.14 \pm 0.07$ \\
\hline $\begin{array}{l}\text { Canada buffaloberry } \\
\text { Cornaceae }\end{array}$ & Shepherdia canadensis & SHE CAN & $5.24 \pm 1.01$ \\
\hline $\begin{array}{l}\text { Red-osier dogwood } \\
\text { Ericaceae }\end{array}$ & Cornus stolonifera & COR STO & $0.05 \pm 0.04$ \\
\hline Common labrador tea & Ledum groenlandicum & LED GRO & $0.08 \pm 0.08$ \\
\hline
\end{tabular}


TABLE 5.1 cont.

\begin{tabular}{|c|c|c|c|}
\hline Common Name & Species Name & $\begin{array}{l}\text { Species } \\
\text { Code } \\
\end{array}$ & $\begin{array}{l}\text { Mean } \\
\text { Percent Cover }\end{array}$ \\
\hline \multicolumn{4}{|l|}{ Caprifoliaceae } \\
\hline Twining honeysuckle & Lonicera dioica & LON DIO & $0.09 \pm 0.06$ \\
\hline Bracted honeysuckle & Lonicera involucrata & LON INV & $6.27 \pm 1.14$ \\
\hline Low bush-cranberry & Viburnum edule & VIB EDU & $4.28 \pm 0.75$ \\
\hline $\begin{array}{l}\text { Tree Total Cover }(<0.5 \mathrm{~m}) \\
\quad \text { Pinaceae }\end{array}$ & & & $0.07 \pm 0.04$ \\
\hline $\begin{array}{l}\text { White spruce } \\
\text { Salicaceae }\end{array}$ & Picea glauca & PIC GLA & $0.01 \pm 0.01$ \\
\hline $\begin{array}{l}\text { Trembling aspen } \\
\text { Betulaceae }\end{array}$ & Populus tremuloides & POP TRE & $0.05 \pm 0.04$ \\
\hline Paper birch & Betula papyrifera & BET PAP & $0.01 \pm 0.01$ \\
\hline $\begin{array}{l}\text { Tree Total Cover }(0.5-1.5 \mathrm{~m}) \\
\text { Pinaceae }\end{array}$ & & & $0.87 \pm 0.31$ \\
\hline $\begin{array}{l}\text { White spruce } \\
\text { Salicaceae }\end{array}$ & Picea glauca & PIC GLA & $0.04 \pm 0.04$ \\
\hline $\begin{array}{l}\text { Trembling aspen } \\
\text { Betulaceae }\end{array}$ & Populus tremuloides & POP TRE & $0.74 \pm 0.28$ \\
\hline Paper birch & Betula papyrifera & BET PAP & $0.08 \pm 0.08$ \\
\hline
\end{tabular}




\section{Whitecourt Study Area}

Seventy-six vascular species (including 53 herbs, 19 shrubs, and 4 tree species) and 22 nonvascular species (19 mosses and 3 lichens) were found in the herb strata (Table 5.2). Within the herb strata moss, litter and herbs were equally abundant $(31 \%, 30 \%$ and $28 \%$ cover respectively). Knight's plume ( $17 \%$ cover) and Big red stem ( $15 \%$ cover) were the most abundant moss species. Bunchberry was the most abundant herb (4\% cover) with Common Labrador tea ( $3 \%$ cover) and Velvet-leaved blueberry ( $2 \%$ cover) the most abundant shrubs in the herb strata. Balsam fir was the most abundant tree species in both the herb and shrub strata (Table 5.2).

The shrub strata contained a total of 20 species, of which 14 were shrubs and 6 were trees (Table 5.2). Five shrub species found in the herb strata were not found in the shrub strata. Devil's club ( $2 \%$ cover) was the most abundant shrub species in the shrub strata. Balsam poplar and Trembling aspen were the only tree species found in the shrub strata and not the herb strata.

\section{Discussion}

The Grande Prairie study area had a well developed herb and shrub strata; shrubs were tall and abundant throughout the study area and the herbs covered a majority of the ground space. This abundance may have been due to the deciduous canopy allowing light to penetrate through to the herb and shrub strata.
The Whitecourt study area had a high density of coniferous trees (Chapter 4). The herb and shrub strata were less developed in this area, possibly due to shading. An abundant moss community was present, possibly as a result of the shaded and damp conditions.

Due to funding constraints only preliminary surveys and summary were conducted for the preharvest understory vegetation.

\section{Future research}

Surveys and analysis of post harvest understory vegetation will take place during 1999/2000. Methods will be similar to those presented above but to obtain adequate data, all 1-ha sites will be surveyed (ie. twice the intensity of the surveys during 1997). Twenty and ten supplemental herb and shrub plots respectively will be surveyed within each stand. Half of the supplemental plots will be within residual tree clumps and the other half $>100 \mathrm{~m}$ (>109 yd.) from residual tree plots.

\section{Literature cited}

Moss, E.H. 1992. Flora of Alberta, $2^{\text {nd }}$ edition. Revised by J.G. Packer. University of Toronto Press, Toronto.

Vitt, D.H., J.E. Marsh, and R.B. Bovey. 1988. Mosses, lichens \& ferns of northwest North America. Lone Pine Publishing, Edmonton, Alberta. 
TABLE 5.2. Mean percent cover ( \pm SE) of understory vegetation for the Whitecourt study area during 1997. Individual species are grouped by strata level and family.

\begin{tabular}{|c|c|c|c|}
\hline Common Name & Species Name & $\begin{array}{l}\text { Species } \\
\text { Code }\end{array}$ & $\begin{array}{l}\text { Mean } \\
\text { Percent Cover }\end{array}$ \\
\hline Litter Total Cover & & & $29.56 \pm 1.08$ \\
\hline Wood Total Cover & & & $4.76 \pm 0.36$ \\
\hline Lichen Total Cover & & & $0.08 \pm 0.04$ \\
\hline club lichen & Cladonia spp. & CLA SPP & $0.01 \pm 0.01$ \\
\hline Studded leather lichen & Peltigera aphthosa & PEL APH & $0.01 \pm 0.01$ \\
\hline Finger felt lichen & Peligera neopolydactyla & PEL NEO & $0.04 \pm 0.03$ \\
\hline Moss Total Cover & & & $30.61 \pm 1.28$ \\
\hline sphagnum & Sphagnum spp. & SPH SPP & $3.74 \pm 0.68$ \\
\hline Common hair-cap & Polytrichum commune & POL COM & $0.39 \pm 0.12$ \\
\hline Juniper hair-cap & Polytrichum juniperinum & POL JUN & $0.30 \pm 0.08$ \\
\hline Slender hair-cap & Polytrichum strictum & POL STR & $0.49 \pm 0.12$ \\
\hline Common northern lantern moss & Cinclidium stygium & CIN STY & $1.46 \pm 0.20$ \\
\hline Knight's plume & Ptilium crista-castrensis & PTI CRI & $17.46 \pm 1.03$ \\
\hline Big red stem & Pleurozium schreberi & PLE SCH & $14.75 \pm 0.91$ \\
\hline Stair-step moss & Hylocomium splendens & HYL SPL & $0.80 \pm 0.14$ \\
\hline Broom moss & Dicranum scoparium & DIC SCO & $0.27 \pm 0.06$ \\
\hline unknown mosses & & MOSS & $0.56 \pm 0.39^{3}$ \\
\hline Grass Total Cover & & & $3.10 \pm 0.36$ \\
\hline $\begin{array}{l}\text { Herb Total Cover } \\
\text { Lycopodiaciaceae }\end{array}$ & & & $28.24 \pm 0.95$ \\
\hline Stiff club-moss & Lycopodium annotinum & LYC ANN & $2.61 \pm 0.21$ \\
\hline $\begin{array}{l}\text { Ground-cedar } \\
\text { Equisetaceae }\end{array}$ & Lycopodium complanatum & LYC COM & $0.03 \pm 0.02$ \\
\hline Common horsetail & Equisetum arvense & EQU ARV & $0.52 \pm 0.08$ \\
\hline $\begin{array}{l}\text { Woodland horsetail } \\
\text { Polypodiaceae }\end{array}$ & Equisetum sylvaticum & EQU SYL & $0.76 \pm 0.13$ \\
\hline Lady fern & Athyrium filix-femina & ATH FIL & $1.91 \pm 0.49$ \\
\hline Oak fern & Gymnocarpium dryopteris & GYM DRY & $2.53 \pm 0.21$ \\
\hline $\begin{array}{l}\text { Cyperaceae } \\
\text { unknown sedge } \\
\text { Liliaceae }\end{array}$ & Carex spp. & SED SPP & $0.01 \pm 0.01$ \\
\hline Fairybells & Disporum trachycarpum & DIS TRA & $0.48 \pm 0.08$ \\
\hline Wild lily-of-the-valley & Maianthemum canadense & MAI CAN & $0.22 \pm 0.04$ \\
\hline Faise solomon's-seal & Smilacina racemosa & SMI RAC & $0.01 \pm 0.01$ \\
\hline Star-flowered false solomon's-seal & Smilacina stellata & SMI STE & $0.03 \pm 0.02$ \\
\hline Three-leaved false solomon's-seal & Smilacina trifolia & SMI TRI & $0.05 \pm 0.02$ \\
\hline unknown lily & Smilacina spp. & SMI SPP & $0.02 \pm 0.01$ \\
\hline $\begin{array}{l}\text { Indian hellebore } \\
\text { Orchidaceae }\end{array}$ & Veratrum viride & VER VIR & $0.04 \pm 0.03$ \\
\hline Heart-leaved twayblade & Listera cordata & LIS COR & $0.01 \pm 0.00$ \\
\hline
\end{tabular}

\footnotetext{
${ }^{3}$ Sum of ten unidentified moss species.
} 


\begin{tabular}{|c|c|c|c|}
\hline Common Name & Species Name & $\begin{array}{l}\text { Species } \\
\text { Code } \\
\end{array}$ & $\begin{array}{l}\text { Mean } \\
\text { Percent Cover }\end{array}$ \\
\hline Urticaceae & & & \\
\hline $\begin{array}{l}\text { Stinging nettle } \\
\text { Ranunculaceae }\end{array}$ & Urtica dioica & URT DIO & $0.05 \pm 0.03$ \\
\hline Red and white baneberry & Actaea rubra & ACT RUB & $0.05 \pm 0.03$ \\
\hline Goldthread & Coptis trifolia & COP TRI & $0.16 \pm 0.04$ \\
\hline Tall larkspur & Delphinium glaucum & DEL GLA & $0.01 \pm 0.01$ \\
\hline $\begin{array}{l}\text { Veiny meadow rue } \\
\text { Saxifragaceae }\end{array}$ & Thalictrum venulosum & THA VEN & $0.03 \pm 0.01$ \\
\hline Bishop's cap & Mitella nuda & MIT NUD & $0.58 \pm 0.07$ \\
\hline $\begin{array}{l}\text { Three-leaved foamflower } \\
\text { Rosaceae }\end{array}$ & Tiarella trifoliata & TIA TRI & $1.38 \pm 0.16$ \\
\hline Wild strawberry & Fragaria virginiana & FRA VIR & $0.02 \pm 0.01$ \\
\hline Purple avens & Geum rivale & GEU RIV & $0.02 \pm 0.01$ \\
\hline Cloudberry & Rubus chamaemorus & RUB CHA & $0.30 \pm 0.09$ \\
\hline Five-leaved bramble & Rubus pedatus & RUB PED & $2.90 \pm 0.22$ \\
\hline $\begin{array}{l}\text { Dewberry } \\
\text { Leguminosae }\end{array}$ & Rubus pubescens & RUB PUB & $1.91 \pm 0.15$ \\
\hline $\begin{array}{l}\text { Creamy peavine } \\
\text { Balsaminaceae }\end{array}$ & Lathyrus ochroleucus & LAT OCH & $0.01 \pm 0.01$ \\
\hline $\begin{array}{l}\text { Spotted touch-me-not } \\
\text { Violaceae }\end{array}$ & Impatiens capensis & IMP CAP & $0.01 \pm 0.01$ \\
\hline $\begin{array}{l}\text { Kidney-leaved violet } \\
\text { Onagraceae }\end{array}$ & Viola renifolia & VIO REN & $0.19 \pm 0.04$ \\
\hline Small enchanter's nightshade & Circaea alpina & CIR ALP & $0.01 \pm 0.01$ \\
\hline $\begin{array}{l}\text { Fireweed } \\
\text { Araliaceae }\end{array}$ & Epilobium angustifolium & EPI ANG & $0.93 \pm 0.11$ \\
\hline $\begin{array}{l}\text { Wild sarsaparilla } \\
\text { Umbelliferae }\end{array}$ & Aralia nudicaulis & ARA NUD & $2.36 \pm 0.25$ \\
\hline $\begin{array}{l}\text { Cow-parsnip } \\
\text { Cornaceae }\end{array}$ & Heracleum lanatum & HER LAN & $0.06 \pm 0.06$ \\
\hline $\begin{array}{l}\text { Bunchberry } \\
\text { Pyrolaceae }\end{array}$ & Cornus canadensis & COR CAN & $4.34 \pm 0.20$ \\
\hline One-sided wintergreen & Orthilia secunda & ORT SEC & $0.01 \pm 0.00$ \\
\hline Common pink wintergreen & Pyrola asarifolia & PYR ASA & $0.29 \pm 0.06$ \\
\hline $\begin{array}{l}\text { Green wintergreen } \\
\text { Boraginaceae }\end{array}$ & Pyrola virens & PYR VIR & $0.05 \pm 0.02$ \\
\hline $\begin{array}{l}\text { Tall lungwort } \\
\text { Scrophulariaceae }\end{array}$ & Mertensia paniculata & MER PAN & $0.29 \pm 0.07$ \\
\hline $\begin{array}{l}\text { Common red paintbrush } \\
\text { Rubiaceae }\end{array}$ & Castilleja miniata & CAS MIN & $0.01 \pm 0.01$ \\
\hline Northern bedstraw & Galium boreale & GAL BOR & $0.01 \pm 0.00$ \\
\hline $\begin{array}{l}\text { Sweet-scented bedstraw } \\
\text { Caprifoliaceae }\end{array}$ & Galium triflorum & GAL TRI & $0.06 \pm 0.02$ \\
\hline $\begin{array}{l}\text { Twinflower } \\
\text { Compositae }\end{array}$ & Linnaea borealis & LIN BOR & $1.94 \pm 0.15$ \\
\hline Heart-leaved arnica & Arnica cordifolia & ARN COR & $0.29 \pm 0.06$ \\
\hline Narrow-leaved hawkweed & Hieracium umbellatum & HIE UMB & $0.03 \pm 0.03$ \\
\hline Palmate-leaved coltsfoot & Petasites palmatus & PET PAL & $0.65 \pm 0.08$ \\
\hline Arrow-leaved groundsel & Senecio triangularis & SEN TRI & $0.01 \pm 0.01$ \\
\hline Late goldenrod & Solidago gigantea & SOL GIG & $0.03 \pm 0.03$ \\
\hline Common dandelion & Taraxacum officinale & TAR OFF & $0.01 \pm 0.01$ \\
\hline
\end{tabular}


TABLE 5.2 cont.

\begin{tabular}{|c|c|c|c|}
\hline Common Name & Species Name & $\begin{array}{l}\text { Species } \\
\text { Code }\end{array}$ & $\begin{array}{l}\text { Mean } \\
\text { Percent Cover }\end{array}$ \\
\hline unknowns & & UNK & $0.06 \pm 0.06^{4}$ \\
\hline $\begin{array}{c}\text { Shrub Total Cover }(<0.5 \mathrm{~m}) \\
\text { Salicaceae }\end{array}$ & & & $10.63 \pm 0.52$ \\
\hline $\begin{array}{l}\text { willow } \\
\text { Betulaceae }\end{array}$ & Salix spp. & SAL SPP & $0.01 \pm 0.01$ \\
\hline Green alder & Alnus crispa & ALN CRI & $0.04 \pm 0.02$ \\
\hline $\begin{array}{r}\text { River alder } \\
\text { Grossulariaceae }\end{array}$ & Alnus tenuifolia & ALN TEN & $0.01 \pm 0.01$ \\
\hline Northern black currant & Ribes hudsonianum & RIB HUD & $0.02 \pm 0.02$ \\
\hline Northern gooseberry & Ribes oxyacanthoides & RIB OXY & $0.47 \pm 0.09$ \\
\hline Wild red currant & Ribes triste & RIB TRI & $0.11 \pm 0.04$ \\
\hline $\begin{array}{l}\text { unknown currant } \\
\text { Rosaceae }\end{array}$ & Ribes spp. & RIB SPP & $0.06 \pm 0.02$ \\
\hline Saskatoon & Amelanchier alnifolia & AME ALN & $0.09 \pm 0.04$ \\
\hline Prickly rose & Rosa asicularis & ROS ACI & $0.95 \pm 0.11$ \\
\hline Wild red raspberry & Rubus idaeus & RUB IDA & $0.33 \pm 0.09$ \\
\hline $\begin{array}{l}\text { Western mountain ash } \\
\text { Araliaceae }\end{array}$ & Sorbus scopulina & SOR SCO & $0.01 \pm 0.01$ \\
\hline $\begin{array}{l}\text { Devil's club } \\
\text { Ericeaceae }\end{array}$ & Oplopanax horridum & OPL HOR & $0.91 \pm 0.26$ \\
\hline Creeping snowberry & Gaultheria hispidula & GAU HIS & $0.56 \pm 0.09$ \\
\hline Common Labrador tea & Ledum groenlandicum & LED GRO & $2.55 \pm 0.28$ \\
\hline Black huckleberry & Vaccinium membranaceum & VAC MEM & $0.16 \pm 0.05$ \\
\hline Velvet-leaved blueberry & Vaccinium myrtilloides & VAC MYR & $2.12 \pm 0.21$ \\
\hline $\begin{array}{l}\text { Bog cranberry } \\
\text { Caprifoliaceae }\end{array}$ & Vaccinium vitis-idaea & VAC VIT & $0.92 \pm 0.12$ \\
\hline Bracted honeysuckle & Lonicera involucrata & LON INV & $0.60 \pm 0.1$ \\
\hline Low bush-cranberry & Viburnum edule & VIB EDU & $0.72 \pm 0.11$ \\
\hline $\begin{array}{l}\text { Shrub Total Cover }(>0.5 \mathrm{~m}) \\
\quad \text { Salicaceae }\end{array}$ & & & $7.00 \pm 0.72$ \\
\hline $\begin{array}{l}\text { willow } \\
\text { Betulaceae }\end{array}$ & Salix spp. & SAL SPP & $0.32 \pm 0.09$ \\
\hline Green alder & Alnus crispa & ALN CRI & $1.05 \pm 0.34$ \\
\hline $\begin{array}{r}\text { River alder } \\
\text { Grossulariaceae }\end{array}$ & Alnus tenuifolia & ALN TEN & $0.17 \pm 0.11$ \\
\hline Northern black currant & Ribes hudsonianum & RIB HUD & $0.04 \pm 0.04$ \\
\hline Northern gooseberry & Ribes oxyacanthoides & RIB OXY & $0.14 \pm 0.06$ \\
\hline Wild red currant & Ribes triste & RIB TRI & $0.01 \pm 0.01$ \\
\hline $\begin{array}{l}\text { unknown currant } \\
\text { Rosaceae }\end{array}$ & Ribes spp. & RIB SPP & $0.03 \pm 0.02$ \\
\hline Saskatoon & Amelanchier alnifolia & AME ALN & $0.01 \pm 0.01$ \\
\hline Prickly rose & Rosa acicularis & ROS ACI & $1.20 \pm 0.18$ \\
\hline $\begin{array}{l}\text { Wild red raspberry } \\
\text { Araliaceae }\end{array}$ & Rubus idaeus & RUB IDA & $0.16 \pm 0.13$ \\
\hline $\begin{array}{l}\text { Devil's club } \\
\text { Ericaceae }\end{array}$ & Oplopanax horridum & OPL HOR & $1.57 \pm 0.44$ \\
\hline Common Labrador tea & Ledum groenlandicum & LED GRO & $1.06 \pm 0.24$ \\
\hline
\end{tabular}

${ }^{4}$ Sum of four identified herb species. 
TABLE 5.2 cont.

\begin{tabular}{|c|c|c|c|}
\hline Common Name & Species Name & $\begin{array}{l}\text { Species } \\
\text { Code }\end{array}$ & $\begin{array}{l}\text { Mean } \\
\text { Percent Cover }\end{array}$ \\
\hline \multicolumn{4}{|l|}{ Caprifoliaceae } \\
\hline Bracted honeysuckle & Lonicera involucrata & LON INV & $0.66 \pm 0.19$ \\
\hline Low bush-cranberry & Viburnum edule & VIB EDU & $0.59 \pm 0.13$ \\
\hline $\begin{array}{l}\text { Tree Total Cover }(<0.5 \mathrm{~m}) \\
\text { Pinaceae }\end{array}$ & & & $0.49 \pm 0.10$ \\
\hline Balsam fir & Abies balsamea & ABI BAL & $0.40 \pm 0.09$ \\
\hline White spruce & Picea glauca & PIC GLA & $0.01 \pm 0.01$ \\
\hline Black spruce & Picea mariana & PIC MAR & $0.02 \pm 0.01$ \\
\hline Betulaceae & & & \\
\hline Paper birch & Betula papyrifera & BET PAP & $0.07 \pm 0.03$ \\
\hline $\begin{array}{l}\text { Tree Total Cover }(0.5-1.5 \mathrm{~m}) \\
\text { Pinaceae }\end{array}$ & & & $1.78 \pm 0.27$ \\
\hline Balsam fir & Abies balsamea & ABI BAL & $1.03 \pm 0.23$ \\
\hline White spruce & Picea glauca & PIC GLA & $0.01 \pm 0.01$ \\
\hline $\begin{array}{l}\text { Black spruce } \\
\text { Salicaceae }\end{array}$ & Picea mariana & PIC MAR & $0.16 \pm 0.06$ \\
\hline Balsam poplar & Populus balsamifera & POP BAL & $0.02 \pm 0.02$ \\
\hline $\begin{array}{l}\text { Trembling aspen } \\
\text { Betulaceae }\end{array}$ & Populus tremuloides & POP TRE & $0.03 \pm 0.02$ \\
\hline Paper birch & Betula papyrifera & BET PAP & $0.53 \pm 0.13$ \\
\hline
\end{tabular}




\title{
CHAPTER 6. ABUNDANCE AND SPECIES COMPOSITION OF CARABID BEETLES IN RELATION TO THE DISPERSION OF RESIDUAL TREES FOLLOWING HARVEST
}

\author{
Troy C. Sorensen
}

\section{Introduction}

Although arthropods compose a large proportion of the biodiversity in most ecosystems; the influence of forestry practices on these taxa is often overlooked. Recent studies have suggested that ground beetles (Coleoptera: Carabidae) may be sensitive to forestry practices and serve as ecological indicators (Thiele 1977, Butterfield et al. 1995). Arthropod communities are influenced by forestry practices because they are sensitive to temperature (Ericson 1979), moisture (Niemela et al. 1992, Niemela and Spence 1994), ground litter (Greenslade 1964), and understory and canopy cover (Niemela and Spence 1994). Furthermore, the dispersion of suitable habitat patches will influence community composition because dispersal is energetically expensive (Atkins 1969) and species differ in their ability to disperse (Thiele 1977).

Boreal communities of carabid beetles have been studied in relation to seasonal changes (Niemela et al. 1992, Digweed et al. 1995), edge effects (Halme and Niemela 1993, Spence et al. 1996), fragmentation (Halme and Niemela 1993), post-harvest regeneration (Spence et al. 1996), and post-fire regeneration (Holliday 1991, 1992; Spence et al. 1996). The main objective of this project is to determine the influence of residual tree dispersion on the species composition and abundance of carabid beetles in aspen-dominated and pine-sprucedominated boreal forests of western Alberta. Specifically, I will examine whether the carabid community within and surrounding residual patches varies among treatments (see Chapter 2 for a description of the treatments), and (2) whether differences among treatments can be explained by microhabitat preferences or dispersal capabilities of specific species.

\section{Future Research}

Due to funding constraints, carabid beetles were not surveyed during 1997. Surveys from four stands of unharvested forest within each study area will serve as benchmarks for post-harvest data.

Carabid beetles will be surveyed with pitfall traps because the traps are effective (Obrtel 1971, Luff 1975, Niemela et al. 1986, Spence and Niemela 1994, Digweed et al. 1995), and results will be comparable to previous studies (Spence et al. 1996). Furthermore, pitfall traps sample a variety of other taxa including ants and spiders that could be identified and analyzed at a later date if funding becomes available. Pitfall traps have been criticized because they sample activity rather than abundance and therefore catches over short durations are dependent on weather and the period of life cycle (Ericson 1979). However, if traps are open for weeks at a time, and sampling occurs at multiple times during the snow-free portion of a year, the effect of weather will be negligible and catches are correlated with density (Baars 1979, Ericson 1979).

Pitfall traps will consist of a removable $500 \mathrm{ml}$ ( 0.53 qt.) plastic container set inside a larger permanent container [1L (1.06 qt.)] so that repeated sampling will not disturb the soil and litter around the trap (Spence and Nimela 1994, Digweed et al. 1995). Each trap will be partially filled $2-3 \mathrm{~cm}(0.8-1.2 \mathrm{in}$.) with undiluted ethylene glycol to increase trap effectiveness and preserve the specimens (Holopainen 1992). A $15 \times 15 \mathrm{~cm}$ (5.9 x 5.9 in.) plywood cover will be suspended with nails over each trap to prevent rain, leaves, and litter from falling into the traps (Spence and Niemela 1994). Trapping will occur during the first two weeks of each month from early May to the middle of September for a total of 5 trapping 
sessions. Traps will be left open for 2 weeks at a time with a 2 week recuperation period between trapping sessions (traps closed) to prevent population depletion.

Traps will be placed along radial transects from the center of residual patches in harvested stands, and along similar transects in the unharvested stands (Fig. 6.1). Transects will begin at the center of the patch and end at the half-way point between patches in the harvested areas. The number of traps in each stand will be similar; however the number of traps used to sample each patch, and the number of patches sampled within each stand will depend on the treatment (Fig. 6.1). Single traps will be placed no less than $20 \mathrm{~m}$ apart to insure independent catches (see Digweed et al. 1995). Previous studies caught fewer (67\% less) beetles in pinedominated than aspen-dominated forests (Spence et al. 1996); to compensate, the number of traps in each stand will be higher in the Whitecourt study area (24 traps) than the Grande Prairie area (16-18 traps). Carabid beetles will be identified to species according to Lindroth (1961-1969). Reference collections are available at the Strickland Museum, University of Alberta, and at the Northern Forestry Centre, Canadian Forest Service, Edmonton.

\section{Literature cited}

Atkins, M.D. 1969. Lipid loss with flight in the Douglas-Fir beetle. The Canadian

Entomologist 101: 164-165.

Baars, M.A. 1979. Catches in pitfall traps in relation to mean densities of carabid beetles. Oecologia (Berl.) 41: 25-46.

Butterfield, J., M.L. Luff, M. Baines, and M.D. Eyre. 1995. Carabid beetle communities as indicators of conservation potential in upland forests. Forest Ecology and Management 79: 63-77.

Digweed, S.C., C.R. Currie, H.A. Carcamo, and J.R. Spence. 1995. Digging out the "diggingin effect" of pitfall traps: influences of depletion and disturbance on catches of ground beetles (Coleoptera: Carabidae). Pedobiologia 39: 561-576.
Ericson, D. 1979. The interpretation of pitfall catches of Pterostichus cupreus and Pt. melanarius (Coleoptera, Carabidae) in cereal fields. Pedobiologia 19: 320-328.

Greenslade, P.J.M. 1964. Pitfall trapping as a method for studying populations of Carabidae (Coleoptera). Journal of Animal Ecology 33: 301-310.

Halme, E. and J.K. Niemela. 1993. Carabid beetles in fragments of coniferous forest. Annales Zoologica Fennici 30: 17-30.

Holliday, N.J. 1991. Species responses of carabid beetles (Coleoptera; Carabidae) during post-fire regeneration of boreal forest. Canadian Entomologist 123: 1369-1389.

Holliday, N.J. 1992. The carabid fauna (Coleoptera: Carabidae) during postfire regeneration of boreal forest: properties and dynamics of species assemblages. Canadian Journal of Zoology 70: 440-452.

Holopainen, J.K. 1992. Catch and sex ratio of Carabidae (Coleoptera) in pitfall traps filled with ethylene glycol or water. Pedobiologia 36: 257-261.

Lindroth, C.H. 1961-1969. The ground-beetles of Canada and Alaska: Parts 1-6. Opuscula Entomologica Supplementa 20, 24, 29, 33, 34, 35.

Luff, M.L. 1975. Some features influencing the efficiency of pitfall traps. Oecologia 19: 345357.

Niemela, J.K., E. Halme, T. Pajunen, and Y. Haila. 1986. Sampling spiders and carabid beetles with pitfall traps: the effect of increased sampling effort. Annales Entomologici Fennici 52: 109-111.

Niemela, J.K. and J.R. Spence. 1994. Distribution of forest dwelling carabids (Coleoptera): spatial scale and the concept of communities. Ecography 17: 166-175.

Niemela, J.K., J.R. Spence, and D.H. Spence. 1992. Habitat associations and seasonal activity of ground-beetles (Coleoptera, Carabidae) in central Alberta. The Canadian Entomologist 124: 521-540. 


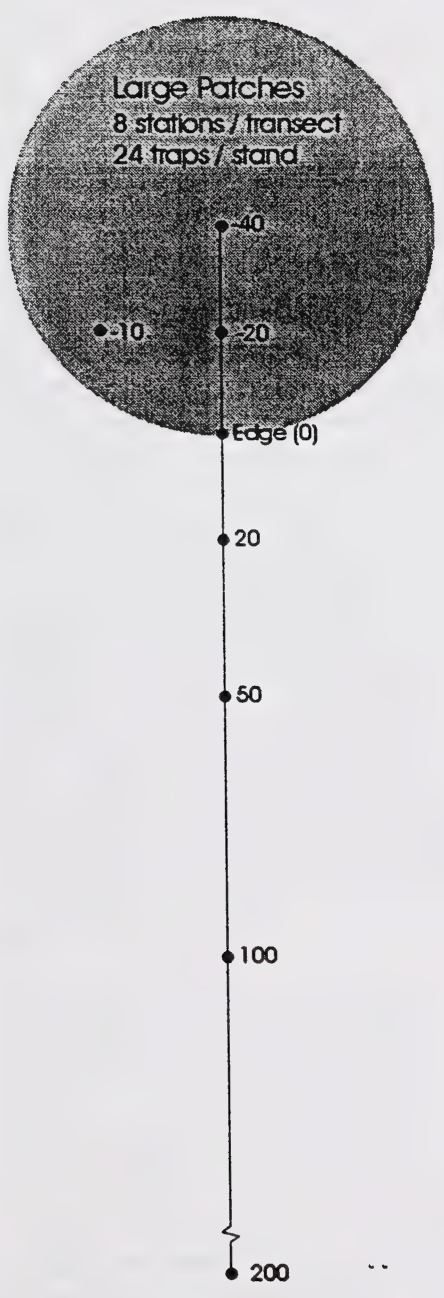

Medium Patches

$5+1$ stations / transect 24 traps / stand

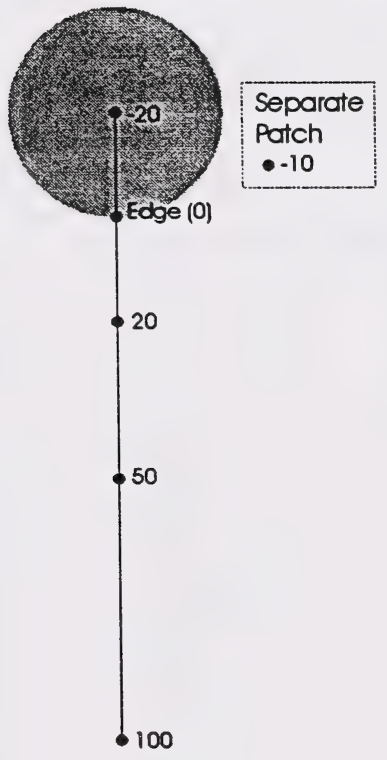

Small Patches $3+1$ stations / transect 24 traps / stand

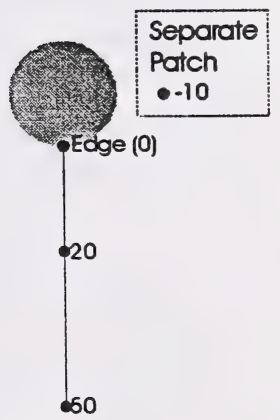

Figure 6.1. Locations of pitfall traps for the three patch sizes in the Whitecourt Area. Trapping design is similar for the Grande Prairie study area with the following distances from patch edges: $-50 \mathrm{~m},-20 \mathrm{~m},-10 \mathrm{~m}, 0 \mathrm{~m}, 20 \mathrm{~m}, 50 \mathrm{~m}, 120 \mathrm{~m}$, and $250 \mathrm{~m}$ (- 55 yd., -22 yd., -11 yd., 0 yd., 22 yd., 55 yd., 131 yd., and 273 yd.). Traps must be at least $20 \mathrm{~m}$ ( 22 yd.) apart to insure statistical independence. Traps will be placed along transects in unharvested forest with the same spacing as the traps in large patches. 
Obrtel, R. 1971. Number of pitfall traps in relation to the structure of the catch of soil surface Coleoptera. Acta Entomol.

Bohemslov. 68: 300-309.

Spence, J.R., D.W. Langor, J.K. Niemela, H.A. Carcamo, and C.R. Currie. 1996. Northern forestry and carabids: the case for concern about old-growth species. Annales Zoologica Fennici 33: 173-184.

Spence, J.R. and J.K. Niemela. 1994. Sampling carabid assemblages with pitfall traps: the madness and the method. Canadian Entomologist 126: 881-894.

Thiele, H.U. 1977. Carabid beetles in their environments. Springer-Verlag, Berlin. 


\title{
CHAPTER 7. VARIATION IN BIRD COMMUNITIES IN RELATION TO THE DISPERSION OF STANDING LIVE TREES AND SNAGS
}

\author{
Jim Schieck
}

\section{Introduction}

As a result of government regulations (e.g. British Columbia Ministry of Forests 1995) and exploratory adaptive management (e.g., AlbertaPacific Forest Industries Inc. 1996) many forest companies have modified harvesting strategies by leaving standing trees and snags in harvested areas. By providing more complex habitat than is found after conventional clear-cut harvest, these residual trees may make the harvest areas more useable by native birds (Schieck et al. 1995, Norton and Hannon 1997). In addition, by providing inputs of large snags and downed logs throughout succession, residual trees may promote recovery of biota in harvested areas (Hobson and Schieck submitted). However, there is little information available to determine the number of residual trees and their spacing that will maximize recovery of native birds. As a result, forest managers are subjectively deciding those patterns (Alberta-Pacific Forest Industries Inc. 1996).

One possible template to follow when leaving standing trees is a natural disturbance model; all else being equal, making harvest areas as similar as possible to natural disturbances probably will be beneficial to native biota since they evolved in an ecosystem with natural disturbances (Urban et al. 1987). Wildfire, disease, and wind-throw events all create natural disturbances in forests, but the dominant natural disturbance in the boreal forests of North America is wildfire (Eberhart and Woodard 1987, Hunter 1993). Thus, wildfire is the most realistic template on which to pattern harvest in the boreal forest. Following wildfires, there are groups of unburned trees (fire skips) embedded within the burnt-over areas (Eberhart and Woodard 1987). Fire skips may retain some of the structures and micro-habitats that were present, and may act as refugia for some of the birds that lived in the forest prior to the disturbance. Fire skips could be emulated in harvest areas by leaving clumps of live trees within cut-blocks. Small clumps may be sufficient for some native biota, but larger clumps probably act as refugia for more species (Saunders et al. 1991, MacKenzie and Steventon 1996, Seip and Parker 1997) because some animals require large undisturbed areas for protection and foraging (Porneluzi et al. 1993, Schmiegelow et al. 1997).

There are limitations, however, to using a wildfire template for harvest because these disturbances remove different amounts of wood from the system. Only a small percentage of the wood is combusted during wildfire resulting in many snags, and when these snags fall, many pieces of downed woody material are present in post-fire areas (Lee et al. 1997). Following harvest, however, most of the wood is removed from the area and the trees that remain are live so that inputs of snags and down woody material is lower and occurs over a longer period than that found after fire. Given this discrepancy, managers should not expect to "mimic" the structure retained after fires and additional management strategies may be needed (Hutto 1995). It may be useful, on at least part of the harvest area, to retain trees in patterns that promote specific groups of native biota that would otherwise "fall through the cracks". One such pattern would be to have single live trees, or small clumps of live trees, scattered throughout the harvest area. If these trees do not get blown down, they will become large by mid-rotation with the result that many of the structures and micro-habitats associated with large live and dead trees will be present in mid-rotation forests rather than only in old forests (Spies et al. 1991). Large live and dead trees that are scattered, although uncommon following wildfires, may accelerate recovery of native biota because many birds use such structures (Hansen et al. 1991, Schieck et al. 1995). With this management strategy, single trees or many small clumps of trees, scattered throughout the harvest area, may have greater 
positive impact on native biota than if all standing trees and snags had been retained as a few large clumps.

When managing for refugia, standing trees are retained in a different pattern than they are when managing for the production of dispersed large trees. Both patterns may be useful, but only by experimentally manipulating size of clumps and distance between clumps, and studying the birds living in those areas will we understand the impacts of each. In this study, we establish three treatments with different clump sizes and distances between clumps in two experimentally harvested areas to evaluate whether bird communities differ among the treatments. This project will evaluate differences that are present immediately following harvest. The experiment, however, will be maintained throughout a harvest rotation and the value of each the three treatments will be evaluated at various times in the future.

\section{Objectives}

I compared pre-harvest bird communities among stand groups and treatments to evaluate whether bird communities were similar in the treatments prior to harvest. Specifically, I evaluated: (1) whether the bird community that has specialized foraging and nesting requirements for large trees varied among treatments, and (2) whether the resident and migratory bird communities varied among treatments. This is the first year of a 3-year study. Post-harvest bird communities will be compared among the three treatments using data that will be collected during 1998 and 1999. In addition, post-harvest bird communities will be compared to the communities found in other studies within naturally disturbed forests and following different silviculture/harvest treatments.

\section{Methods}

A description of the study areas and experimental harvesting is presented in the Study Area and Methods (Chapter 2). Descriptions of the pre-harvest trees, snags, down woody materials, and understory vegetation is presented in Chapters $3-5$.

\section{Pre-harvest Bird Surveys}

Depending on the shape of the stands, either two or three strip transects $100 \mathrm{~m}$ (109 yd.) wide and having a total length of $1 \mathrm{~km}(0.62 \mathrm{mi}$.), were established in each stand (Figs. 2.1 and 2.2). Strip transects were divided into ten 1-ha sites and permanent markers were located at the center of each site. To avoid censusing birds that lived in adjacent habitats, the outer edge of the strip transects were a minimum of $70 \mathrm{~m}$ (77 yd.), and when possible $>100 \mathrm{~m}$ ( $>109 \mathrm{yd}$.), from adjacent forest types. Birds were surveyed in each stand during four 12-day periods between 9 May and 26 June 1997. During each survey, the center lines of the transects were walked at a rate of $100 \mathrm{~m}$ per $10 \mathrm{~min}$ between first light and three hours past sunrise on days with little wind and no rain. The location of all birds heard or seen within the transects were recorded on maps. A $50 \mathrm{~m}$ (54.7 yd.) detection distance was used because this represents the maximum distance that all bird vocalizations could be detected reliably (Emlen and DeJong 1981, Wolf et al. 1995, Schieck 1997). At the center of each 1-ha (2.47 acre) site a 5-minute point count was conducted. Movements of birds were recorded on maps and summarized so that individual birds were tallied only once. When possible unknown birds were located and identified after the end of each survey. Bird vocalizations that could not be identified in the field were recorded using cassette tape recorders and parabolic microphones and identified later. The order that stands were surveyed during each period was randomly determined. Observers were trained, and methods were standardized prior to the start of the surveys.

\section{Analyses of Pre-harvest Bird Communities} Bird species were categorized based on their migration, nesting, and foraging habits (Campbell et al. 1990, Semenchuk 1992, Gauthier and Auby 1996). Resident and migrant bird species may be affected differently by the dispersion of residual trees because residents live in boreal forests throughout the year. In addition, the dispersion of standing residual trees may have a greater affect on birds that nest or forage in large live or dead trees than those that do not. Tree Swallows (see Table 7.1 for scientific names) were included in the analyses 
TABLE 7.1. Abundance (mean $\pm \mathrm{SE}$ ), migration habits, and nesting/foraging habits of bird species that were detected in the pre-harvest forest in the Whitecourt study area and Grande Prairie study area during 1997.

\begin{tabular}{|c|c|c|c|c|c|}
\hline Common Name & Genus And Species & $\begin{array}{c}\text { Species } \\
\text { Code }\end{array}$ & $\begin{array}{l}\text { Migration } \\
\text { Habits }\end{array}$ & $\begin{array}{c}\text { Use } \\
\text { Big Trees }\end{array}$ & $\begin{array}{l}\text { Mean Abundance } \\
\text { (number/10 ha) }\end{array}$ \\
\hline
\end{tabular}

\begin{tabular}{|c|c|c|c|c|c|c|}
\hline hitecourt Study Area & & & & & & \\
\hline Nothern Goshawk & Accipiter gentilis & NOGO & Resident & Yes & 0.17 & \pm 0.17 \\
\hline Ruffed Grouse & Bonasa umbellus & RUGR & Resident & No & 0.08 & \pm 0.08 \\
\hline Common Snipe & Gallinago gallinago & COSN & Migrant & No & 0.17 & \pm 0.11 \\
\hline Yellow-bellied Sapsucker & Sphyrapicus varius & YBSA & Migrant & Yes & 0.67 & \pm 0.31 \\
\hline Downy Woodpecker & Picoides pubescens & DOWO & Resident & Yes & 0.08 & \pm 0.08 \\
\hline Hairy Woodpecker & Picoides villosus & HAWO & Resident & Yes & 0.33 & \pm 0.14 \\
\hline Three-toed Woodpecker & Picoides tridactylus & TTWO & Resident & Yes & 0.17 & \pm 0.11 \\
\hline Northern Flicker & Colaptes auratus & NOFL & Migrant & Yes & 0.50 & \pm 0.26 \\
\hline Alder Flycatcher & Empidonax alnorum & ALFL & Migrant & No & 0.08 & \pm 0.08 \\
\hline Least Flycatcher & Empidonax minimus & LEFL & Migrant & Yes & 0.08 & \pm 0.08 \\
\hline Tree Swallow & Tachycineta bicolor & TRSW & Migrant & Yes & 0.17 & \pm 0.11 \\
\hline Gray Jay & Perisoreus canadensis & GRJA & Resident & Yes & 1.58 & \pm 0.5 \\
\hline Black-capped Chickadee & Parus atricapillus & $\mathrm{BCCH}$ & Resident & No & 3.83 & \pm 0.69 \\
\hline Boreal Chickadee & Parus hudsonicus & $\mathrm{BOCH}$ & Resident & No & 2.92 & \pm 0.57 \\
\hline Red-breasted Nuthatch & Sitta canadensis & RBNU & Resident & Yes & 1.17 & \pm 0.71 \\
\hline Brown Creeper & Certhia americana & BRCR & Migrant & Yes & 0.25 & \pm 0.18 \\
\hline Winter Wren & Troglodytes troglodytes & WIWR & Migrant & Yes & 0.08 & \pm 0.08 \\
\hline Golden-crowned Kinglet & Regulus satrapa & GCKI & Migrant & Yes & 3.50 & \pm 0.62 \\
\hline Ruby-crowned Kinglet & Regulus calendula & RCKI & Migrant & Yes & 7.25 & \pm 0.58 \\
\hline Swainson's Thrush & Catharus ustulatus & SWTH & Migrant & No & 2.75 & \pm 0.41 \\
\hline Hermit Thrush & Catharus guttatus & HETH & Migrant & No & 1.50 & \pm 0.36 \\
\hline American Robin & Turdus migratoruis & AMRO & Migrant & No & 0.17 & \pm 0.11 \\
\hline Cedar Waxwing & Bombycilla cedrorum & CEWA & Migrant & No & 0.17 & \pm 0.11 \\
\hline Solitary Vireo & Vireo solitarius & SOVI & Migrant & Yes & 1.58 & \pm 0.43 \\
\hline Warbling Vireo & Vireo gilvus & WAVI & Migrant & Yes & 0.58 & \pm 0.19 \\
\hline Red-eyed Vireo & Vireo olivaceus & REVI & Migrant & Yes & 0.33 & \pm 0.22 \\
\hline Orange-crowned Warbler & Vermivora celata & OCWA & Migrant & No & 0.25 & \pm 0.13 \\
\hline Yellow Warbler & Dendroica petechia & YEWA & Migrant & No & 1.08 & \pm 0.34 \\
\hline Yellow-rumped Warbler & Dendroica coronata & YRWA & Migrant & Yes & 10.58 & \pm 0.54 \\
\hline American Redstart & Setophaga ruticilla & AMRE & Migrant & No & 0.17 & \pm 0.11 \\
\hline Ovenbird & Seiurus aurocapillus & OVEN & Migrant & No & 0.25 & \pm 0.13 \\
\hline Mourning Warbler & Oporornis philadelphia & MOWA & Migrant & No & 0.33 & 0.14 \\
\hline Common Yellowthroat & Geothlypis trichas & COYE & Migrant & No & 0.08 & \pm 0.08 \\
\hline Canada Warbler & Wilsonia canadensis & CAWA & Migrant & No & 0.25 & \pm 0.25 \\
\hline Rose-breasted Grosbeak & Pheucticus ludovicianus & RBGR & Migrant & No & 0.08 & \pm 0.08 \\
\hline Chipping Sparrow & Spizella passerina & CHSP & Migrant & Yes & 5.33 & \pm 0.63 \\
\hline Lincoln's Sparrow & Melospiza lincolnii & LISP & Migrant & No & 0.08 & \pm 0.08 \\
\hline White-throated Sparrow & Zonotrichia albicollis & WTSP & Migrant & No & 2.25 & \pm 0.62 \\
\hline Dark-eyed Junco & Junco hyemalis & DEJU & Migrant & No & 4.50 & \pm 0.66 \\
\hline Brown-headed Cowbird & Molothrus ater & $\mathrm{BHCO}$ & Migrant & No & 0.25 & \pm 0.13 \\
\hline White-winged Crossbill & Loxia leucoptera & WWCR & Resident & Yes & 0.08 & \pm 0.08 \\
\hline Pine Siskin & Carduelis pinus & PISI & Migrant & Yes & 1.08 & \pm 0.36 \\
\hline
\end{tabular}


TABLE 7.1. cont.

\begin{tabular}{|c|c|c|c|c|c|}
\hline Common Name & Genus And Species & $\begin{array}{l}\text { Species } \\
\text { Code }\end{array}$ & $\begin{array}{l}\text { Migration } \\
\text { Habits }\end{array}$ & $\begin{array}{c}\text { Use } \\
\text { Big Trees }\end{array}$ & $\begin{array}{l}\text { Mean Abundance } \\
\text { (number/10 ha) }\end{array}$ \\
\hline \multicolumn{6}{|l|}{ Grande Prairie Study Area } \\
\hline Ruffed Grouse & Bonasa umbellus & RUGR & Resident & No & $0.33 \pm 0.14$ \\
\hline Common Snipe & Gallinago gallinago & COSN & Migrant & No & $0.08 \pm 0.08$ \\
\hline Yellow-bellied Sapsucker & Sphyrapicus varius & YBSA & Migrant & Yes & $3.25 \pm 0.41$ \\
\hline Downy Woodpecker & Picoides pubescens & DOWO & Resident & Yes & $0.17 \pm 0.17$ \\
\hline Hairy Woodpecker & Picoides villosus & HAWO & Resident & Yes & $0.33 \pm 0.19$ \\
\hline Northern Flicker & Colaptes auratus & NOFL & Migrant & Yes & $0.67 \pm 0.36$ \\
\hline Pileated Woodpecker & Dryocopus pileatus & PIWO & Resident & Yes & $0.08 \pm 0.08$ \\
\hline Alder Flycatcher & Empidonax alnorum & ALFL & Migrant & No & $0.83 \pm 0.21$ \\
\hline Least Flycatcher & Empidonax minimus & LEFL & Migrant & Yes & $8.33 \pm 1.04$ \\
\hline Tree Swallow & Tachycineta bicolor & TRSW & Migrant & Yes & $0.17 \pm 0.17$ \\
\hline Gray Jay & Perisoreus canadensis & GRJA & Resident & Yes & $0.25 \pm 0.25$ \\
\hline Common Raven & Corvus corax & CORA & Resident & Yes & $0.25 \pm 0.18$ \\
\hline Black-capped Chickadee & Parus atricapillus & $\mathrm{BCCH}$ & Resident & No & $2.58 \pm 0.58$ \\
\hline Boreal Chickadee & Parus hudsonicus & $\mathrm{BOCH}$ & Resident & No & $0.25 \pm 0.13$ \\
\hline Red-breasted Nuthatch & Sitta canadensis & RBNU & Resident & Yes & $0.58 \pm 0.29$ \\
\hline Golden-crowned Kinglet & Regulus satrapa & GCKI & Migrant & Yes & $0.08 \pm 0.08$ \\
\hline Ruby-crowned Kinglet & Regulus calendula & RCKI & Migrant & Yes & $0.42 \pm 0.26$ \\
\hline Veery & Catharus fuscescens & VEER & Migrant & No & $0.08 \pm 0.08$ \\
\hline Swainson's Thrush & Catharus ustulatus & SWTH & Migrant & No & $3.08 \pm 0.43$ \\
\hline Hermit Thrush & Catharus guttatus & HETH & Migrant & No & $1.08 \pm 0.26$ \\
\hline American Robin & Turdus migratoruis & AMRO & Migrant & No & $1.67 \pm 0.53$ \\
\hline Cedar Waxwing & Bombycilla cedrorum & CEWA & Migrant & No & $0.25 \pm 0.18$ \\
\hline Solitary Vireo & Vireo solitarius & SOVI & Migrant & Yes & $0.25 \pm 0.18$ \\
\hline Warbling Vireo & Vireo gilvus & WAVI & Migrant & Yes & $1.25 \pm 0.37$ \\
\hline Red-eyed Vireo & Vireo olivaceus & REVI & Migrant & Yes & $3.92 \pm 0.69$ \\
\hline Tennessee Warbler & Vermivora peregrina & TEWA & Migrant & No & $3.17 \pm 0.82$ \\
\hline Orange-crowned Warbler & Vermivora celata & OCWA & Migrant & No & $0.58 \pm 0.23$ \\
\hline Connecticut Warbler & Oporornis agilis & COWA & Migrant & No & $1.08 \pm 0.29$ \\
\hline Yellow Warbler & Dendroica petechia & YEWA & Migrant & No & $3.83 \pm 0.74$ \\
\hline Magnolia Warbler & Dendroica magnolia & MAWA & Migrant & No & $0.58 \pm 0.23$ \\
\hline Yellow-rumped Warbler & Dendroica coronata & YRWA & Migrant & Yes & $9.50 \pm 0.87$ \\
\hline Black-throated Green Warbler & Dendroica virens & BTGW & Migrant & Yes & $0.33 \pm 0.22$ \\
\hline Blackpoll Warbler & Dendroica striata & BPWA & Migrant & No & $0.08 \pm 0.08$ \\
\hline Black and white Warbler & Mniotilta varia & BWWA & Migrant & No & $0.08 \pm 0.08$ \\
\hline American Redstart & Setophaga ruticilla & AMRE & Migrant & No & $4.67 \pm 1.11$ \\
\hline Ovenbird & Seiurus aurocapillus & OVEN & Migrant & No & $5.92 \pm 0.85$ \\
\hline Northern Waterthrush & Sieurus noveboracensis & NOWA & Migrant & No & $0.33 \pm 0.22$ \\
\hline Mourning Warbler & Oporornis philadelphia & MOWA & Migrant & No & $0.67 \pm 0.28$ \\
\hline Common Yellowthroat & Geothlypis trichas & COYE & Migrant & No & $0.17 \pm 0.11$ \\
\hline Canada Warbler & Wilsonia canadensis & CAWA & Migrant & No & $0.08 \pm 0.08$ \\
\hline Western Tanager & Piranga ludoviciana & WETA & Migrant & Yes & $2.17 \pm 0.55$ \\
\hline Rose-breasted Grosbeak & Pheucticus ludovicianus & RBGR & Migrant & No & $3.83 \pm 1.04$ \\
\hline Chipping Sparrow & Spizella passerina & CHSP & Migrant & Yes & $5.50 \pm 0.96$ \\
\hline Song Sparrow & Melospiza melodia & SOSP & Migrant & No & $0.17 \pm 0.11$ \\
\hline Lincoln's Sparrow & Melospiza lincolnii & LISP & Migrant & No & $1.83 \pm 0.53$ \\
\hline White-throated Sparrow & Zonotrichia albicollis & WTSP & Migrant & No & $15.92 \pm 1.40$ \\
\hline Dark-eyed Junco & Junco hyemalis & DEJU & Migrant & No & $4.58 \pm 0.81$ \\
\hline Red-winged Blackbird & Agelaius phoeniceus & RWBL & Migrant & No & $0.33 \pm 0.19$ \\
\hline Brown-headed Cowbird & Molothrus ater & $\mathrm{BHCO}$ & Migrant & No & $3.08 \pm 0.93$ \\
\hline Pine Siskin & Carduelis pinus & PISI & Migrant & Yes & $1.08 \pm 0.67$ \\
\hline
\end{tabular}


when detected flying within the transect. This species, unlike the other forest birds, does not land in trees or on the ground while foraging (Godfrey 1986, Semenchuk 1992). Other species that flew over during the surveys were not included in the analyses.

For each bird species, an index of density in each 1 ha (2.47 acres) site was calculated as the maximum number of individuals detected during the four surveys. Differences in bird species richness and total abundance were evaluated among stand groups using ANOVA for all bird species together and subsequently and for each of the four categories of bird species (residents versus migrants, and species that use big trees versus those that do not). Since bird species richness and total abundance differed among stand groups (see Results), differences in both were evaluated among treatments after first adjusting for differences among stand groups (Type III sum of squares in a 2-way ANOVA; SAS Institute Inc 1989). In all analyses, results were considered statistically significant if the probability of them occurring by chance was less than 0.05 .

Differences in bird species richness and abundance do not describe all the differences among bird communities because species composition may differ even when richness and abundance are similar. I used correspondence analyses and canonical correspondence analyses (CA and CCA respectively, Halvorsen 1996) to evaluate differences in bird communities among stand groups and treatments. In all CAs and CCAs, the option to down-weight rare species was used (ter Braak 1992) because chance events may have resulted in these rare species being observed in non-typical habitats. Differences among stand groups and treatments were tested by coding dummy variables for the appropriate categories, including these dummy variables as environmental variables in the analyses, and then testing for explained variation using a bootstrap Monte Carlo test with 99 iterations (ter Braak 1992). To evaluate whether variation in bird communities was related to variation in vegetation, I included 16 characteristics of live and dead vegetation in the CCA. Live trees were categorized into three groups: the dominate species (pine in
Whitecourt study area, and aspen in Grande Prairie study area), the second most dominant species (black spruce in Whitecourt study area, and white spruce in Grande Prairie study area), and all other tree species. Within each of these three categories of trees, the densities of trees with $\mathrm{DBH}<$ and $>20 \mathrm{~cm}$ (7.9 in.) was calculated. In addition, in both study areas I calculated densities of snags with $\mathrm{DBH}<$ and $>$ $20 \mathrm{~cm}$ (7.9 in.), volume of downed woody material per ha, and percentage of the ground surface covered by shrubs $<0.5 \mathrm{~m}(<1.6 \mathrm{ft}$.) high, shrubs $>0.5 \mathrm{~m}$ (>1.6 ft.) high, herbs, grass, moss, and dead vegetation.

\section{Results}

\section{Whitecourt Study Area}

Forty-two species and 901 individuals were detected during the bird surveys (Table 7.1). This bird community was dominated by species that migrate with only $24 \%$ of the species being year-round residents. Most residents $(70 \%$ of 10 species), but fewer migrants ( $40 \%$ of 32 species) nested or foraged in large live or dead trees. More bird species (Table 7.2) and individuals (Table 7.3) were observed in stand group B than in the other three stand groups. That difference was largely due to more resident bird species that use large trees being present in stand group B. Species richness and abundance were similar among treatments for all categories of birds after adjusting for differences among stand groups (Tables 7.2 and 7.3).

When evaluating differences in bird communities among sites, the first and second functions of the CA had eigen values of 0.07 and 0.04 , respectively. Combined, these two functions accounted for only $3.4 \%$ of the variation in bird species density. However, even with this small amount of explained variation, bird communities were statistically different among stand groups (Fig. 7.1; $\mathrm{F}=1.8, \mathrm{P}<$ 0.001 ). After adjusting for differences among stand groups, bird communities did not differ among treatments (during the bootstrap Monte Carlo test permutations were restricted to within the appropriate stand group; $F=1.2, P=0.10$ ). In addition, all categories of bird species were present in all stand groups (Fig. 7.2). Variation in the bird communities was not related to 
TABLE 7.2. Mean ( \pm SE) species richness within sites within each stand group and treatment. Species were categorized by whether or not they used large trees or snags and their migration habitats. There were 3 and 121 degrees of freedom for the tests involving stand groups and 2 and 119 degrees of freedom for the tests involving treatments. Groups with different superscripts are statistically different (Student-Neuman-Keuls range test).

\begin{tabular}{|c|c|c|c|c|c|c|}
\hline \multirow[t]{2}{*}{ Categories } & \multirow{2}{*}{$\begin{array}{c}\text { Test } \\
\text { Statistic }\end{array}$} & \multicolumn{2}{|c|}{ Use Big Trees } & \multicolumn{2}{|c|}{ Do Not Use Big Trees } & \multirow{2}{*}{ Total } \\
\hline & & Resident & Migrant & Resident & Migrant & \\
\hline \multicolumn{7}{|c|}{ Whitecourt Study Area } \\
\hline Stand Group A & & $0.2 \pm 0.1^{b}$ & $2.9 \pm 0.2$ & $0.6 \pm 0.1$ & $1.1 \pm 0.1$ & $4.8 \pm 0.3^{\mathrm{ab}}$ \\
\hline Stand Group B & & $0.5 \pm 0.1^{\mathrm{a}}$ & $3.0 \pm 0.2$ & $0.6 \pm 0.1$ & $1.5 \pm 0.2$ & $5.6 \pm 0.4^{a}$ \\
\hline Stand Group C & & $0.2 \pm 0.1^{b}$ & $2.8 \pm 0.2$ & $0.7 \pm 0.1$ & $1.5 \pm 0.2$ & $5.1 \pm 0.3^{2 b}$ \\
\hline \multirow[t]{3}{*}{ Stand Group D } & & $0.2 \pm 0.1^{b}$ & $2.3 \pm 0.3$ & $0.6 \pm 0.1$ & $1.4 \pm 0.2$ & $4.5 \pm 0.4^{b}$ \\
\hline & $\mathrm{F}$ & 3.5 & 1.6 & 1.6 & 0.9 & 2.49 \\
\hline & $\mathbf{P}$ & 0.02 & 0.19 & 0.22 & 0.49 & 0.05 \\
\hline Treatment 1 & & $0.2 \pm 0.1$ & $2.5 \pm 0.2$ & $0.8 \pm 0.1$ & $1.2 \pm 0.2$ & $4.7 \pm 0.3$ \\
\hline Treatment 2 & & $0.3 \pm 0.1$ & $2.9 \pm 0.2$ & $0.5 \pm 0.1$ & $1.5 \pm 0.2$ & $5.3 \pm 0.3$ \\
\hline \multirow[t]{3}{*}{ Treatment 3} & & $0.3 \pm 0.1$ & $2.8 \pm 0.2$ & $0.6 \pm 0.1$ & $1.4 \pm 0.2$ & $5.0 \pm 0.3$ \\
\hline & $\mathrm{F}$ & 0.6 & 0.8 & 0.3 & 1.2 & 1.3 \\
\hline & $\mathbf{P}$ & 0.94 & 0.43 & 0.77 & 0.32 & 0.27 \\
\hline \multicolumn{7}{|c|}{ Grande Prairie Study Area } \\
\hline Stand Group A & & $0.1 \pm 0.1$ & $3.2 \pm 0.2$ & $0.3 \pm 0.1^{a b}$ & $4.1 \pm 0.2^{b}$ & $7.7 \pm 0.4^{b}$ \\
\hline Stand Group B & & $0.1 \pm 0.1$ & $2.7 \pm 0.2$ & $0.4 \pm 0.1^{\mathrm{a}}$ & $4.0 \pm 0.2^{b}$ & $7.3 \pm 0.4^{b}$ \\
\hline Stand Group C & & $0.2 \pm 0.1$ & $3.4 \pm 0.2$ & $0.1 \pm 0.1^{b}$ & $5.3 \pm 0.3^{\mathrm{a}}$ & $9.0 \pm 0.5^{\circ}$ \\
\hline \multirow[t]{3}{*}{ Stand Group D } & & $0.1 \pm 0.1$ & $2.8 \pm 0.2$ & $0.3 \pm 0.1$ & $5.0 \pm 0.3^{\mathrm{a}}$ & $8.2 \pm 0.4^{a}$ \\
\hline & F & 0.2 & 2.5 & 3.2 & 6.4 & 4.6 \\
\hline & $\mathbf{P}$ & 0.92 & 0.06 & 0.03 & 0.001 & 0.001 \\
\hline Treatment 1 & & $0.1 \pm 0.1$ & $3.0 \pm 0.2$ & $0.3 \pm 0.1$ & $4.5 \pm 0.2$ & $7.9 \pm 0.04$ \\
\hline Treatment 2 & & $0.1 \pm 0.1$ & $3.2 \pm 0.2$ & $0.2 \pm 0.1$ & $5.0 \pm 0.3$ & $8.5 \pm 0.06$ \\
\hline \multirow[t]{3}{*}{ Treatment 3} & & $0.1 \pm 0.1$ & $2.9 \pm 0.2$ & $0.3 \pm 0.1$ & $4.3 \pm 0.3$ & $7.6 \pm 0.04$ \\
\hline & $\mathrm{F}$ & 0.6 & 0.8 & 0.3 & 2.3 & 2.2 \\
\hline & $\mathbf{P}$ & 0.94 & 0.44 & 0.77 & 0.10 & 0.14 \\
\hline
\end{tabular}


TABLE 7.3. Mean ( \pm SE) abundance per ha within each stand group and treatment. Species were categorized by whether or not they used large trees or snags and their migration habitats. There were 3 and 121 degrees of freedom for the tests involving stand groups and 2 and 119 degrees of freedom for the tests involving treatments. Groups with different superscripts are statistically different (Student-Neuman-Keuls range test).

\begin{tabular}{|c|c|c|c|c|c|c|}
\hline \multirow[t]{2}{*}{ Categories } & \multirow{2}{*}{$\begin{array}{c}\text { Test } \\
\text { Statistic }\end{array}$} & \multicolumn{2}{|c|}{ Use Big Trees } & \multicolumn{2}{|c|}{ Do Not Use Big Trees } & \multirow{2}{*}{ Total } \\
\hline & & Resident & $\overline{\text { Migrant }}$ & Resident & Migrant & \\
\hline \multicolumn{7}{|l|}{ Whitecourt Study Area } \\
\hline Stand Group A & & $0.4 \pm 0.2$ & $3.3 \pm 0.2$ & $0.6 \pm 0.1$ & $1.2 \pm 0.1$ & $5.5 \pm 0.4$ \\
\hline Stand Group B & & $0.6 \pm 0.1$ & $3.5 \pm 0.3$ & $0.7 \pm 0.1$ & $1.6 \pm 0.2$ & $6.3 \pm 0.5$ \\
\hline Stand Group C & & $0.3 \pm 0.2$ & $3.2 \pm 0.3$ & $0.7 \pm 0.1$ & $1.6 \pm 0.2$ & $5.9 \pm 0.4$ \\
\hline \multirow[t]{3}{*}{ Stand Group D } & & $0.2 \pm 0.1$ & $2.7 \pm 0.3$ & $0.7 \pm 0.1$ & $1.5 \pm 0.2$ & $5.1 \pm 0.4$ \\
\hline & $\mathrm{F}$ & 1.2 & 1.8 & 0.1 & 0.8 & 2.3 \\
\hline & $P$ & 0.31 & 0.14 & 0.95 & 0.46 & 0.08 \\
\hline Treatment 1 & & $0.3 \pm 0.1$ & $2.9 \pm 0.2$ & $0.8 \pm 0.1$ & $1.2 \pm 0.1$ & $5.2 \pm 0.4$ \\
\hline Treatment 2 & & $0.5 \pm 0.1$ & $3.4 \pm 0.3$ & $0.5 \pm 0.1$ & $1.7 \pm 0.2$ & $6.2 \pm 0.5$ \\
\hline \multirow[t]{3}{*}{ Treatment 3} & & $0.3 \pm 0.1$ & $3.2 \pm 0.2$ & $0.7 \pm 0.1$ & $1.4 \pm 0.2$ & $5.6 \pm 0.4$ \\
\hline & $\mathrm{F}$ & 0.4 & 1.3 & 0.5 & 1.7 & 2.0 \\
\hline & $\mathrm{P}$ & 0.65 & 0.29 & 0.61 & 0.19 & 0.11 \\
\hline \multicolumn{7}{|c|}{ Grande Prairie Study Area } \\
\hline Stand Group A & & $0.1 \pm 0.1$ & $3.9 \pm 0.3^{\mathrm{ab}}$ & $0.3 \pm 0.1^{\mathrm{ab}}$ & $5.0 \pm 0.3^{c}$ & $9.3 \pm 0.5^{b}$ \\
\hline Stand Group B & & $0.1 \pm 0.1$ & $3.4 \pm 0.3^{\mathrm{ab}}$ & $0.6 \pm 0.2^{\mathrm{a}}$ & $4.7 \pm 0.3^{c}$ & $8.8 \pm 0.4^{b}$ \\
\hline Stand Group C & & $0.2 \pm 0.1$ & $4.4 \pm 0.4^{\mathrm{a}}$ & $0.1 \pm 0.1^{b}$ & $7.4 \pm 0.5^{\mathrm{a}}$ & $12.0 \pm 0.6^{2}$ \\
\hline \multirow[t]{3}{*}{ Stand Group D } & & $0.2 \pm 0.1$ & $3.1 \pm 0.2^{b}$ & $0.3 \pm 0.1^{\mathrm{ab}}$ & $6.2 \pm 0.4^{b}$ & $9.8 \pm 0.5^{b}$ \\
\hline & F & 0.3 & 3.3 & 3.2 & 11.8 & 9.7 \\
\hline & $\mathbf{P}$ & 0.86 & 0.02 & 0.03 & $<0.001$ & $<0.001$ \\
\hline Treatment 1 & & $0.1 \pm 0.1$ & $3.5 \pm 0.2$ & $0.3 \pm 0.1$ & $5.6 \pm 0.2$ & $9.6 \pm 0.5$ \\
\hline Treatment 2 & & $0.1 \pm 0.1$ & $4.3 \pm 0.4$ & $0.3 \pm 0.1$ & $6.2 \pm 0.3$ & $10.7 \pm 0.6$ \\
\hline \multirow[t]{3}{*}{ Treatment 3} & & $0.2 \pm 0.1$ & $3.3 \pm 0.3$ & $0.3 \pm 0.1$ & $5.5 \pm 0.4$ & $9.6 \pm 0.5$ \\
\hline & $\mathrm{F}$ & 0.4 & 25 & 0.1 & 1.5 & 2.0 \\
\hline & $P$ & 0.66 & 0.09 & 0.87 & 0.22 & 0.11 \\
\hline
\end{tabular}




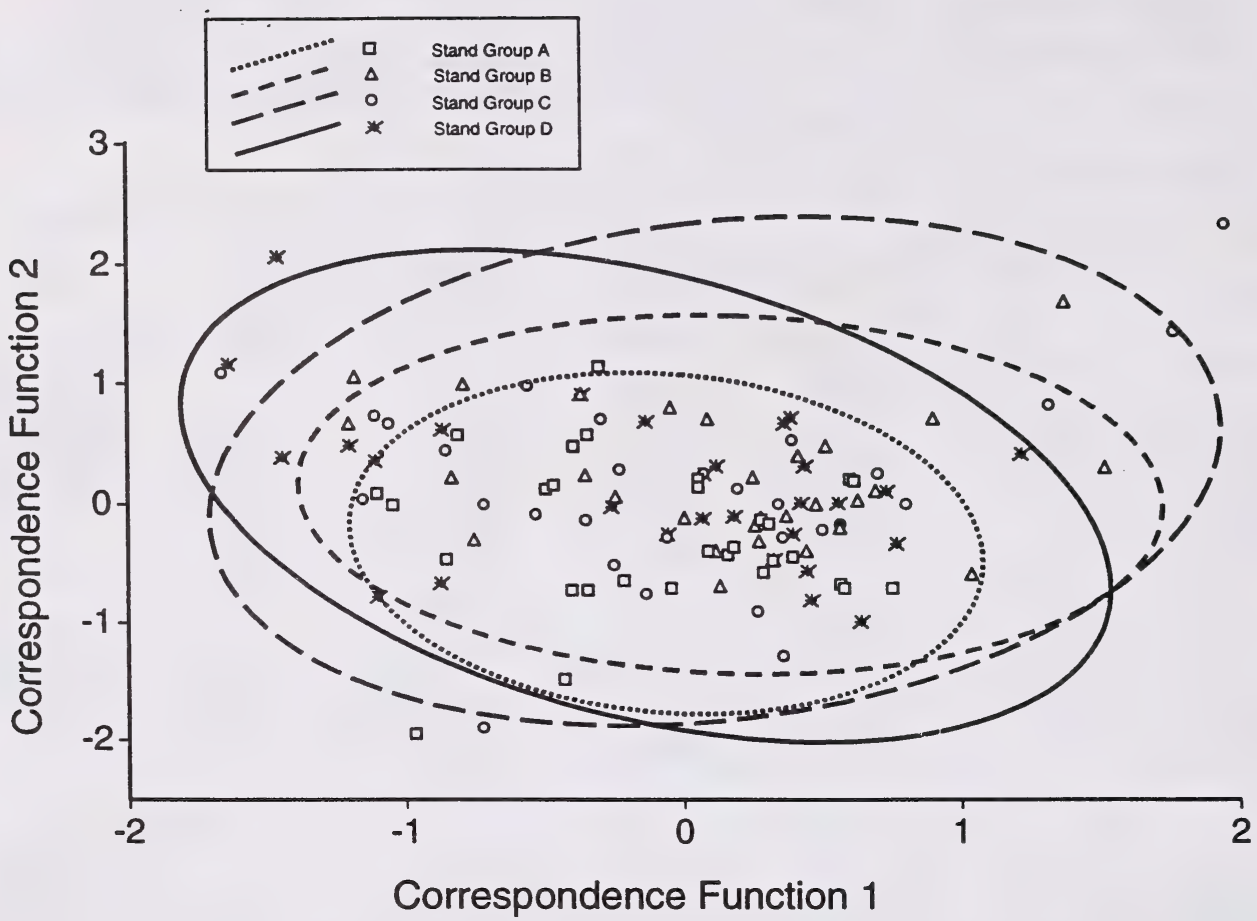

FIGURE 7.1. Correspondence analyses based on bird densities in the Whitecourt study area during 1997. Sites that are close together within the correspondence plot have similar bird communities and sites that are far apart have dissimilar bird communities. Sites were categorized based on stand group. For each stand group bivariate ellipses that enclose $90 \%$ of the sites were presented (Systat Inc. 1989). 


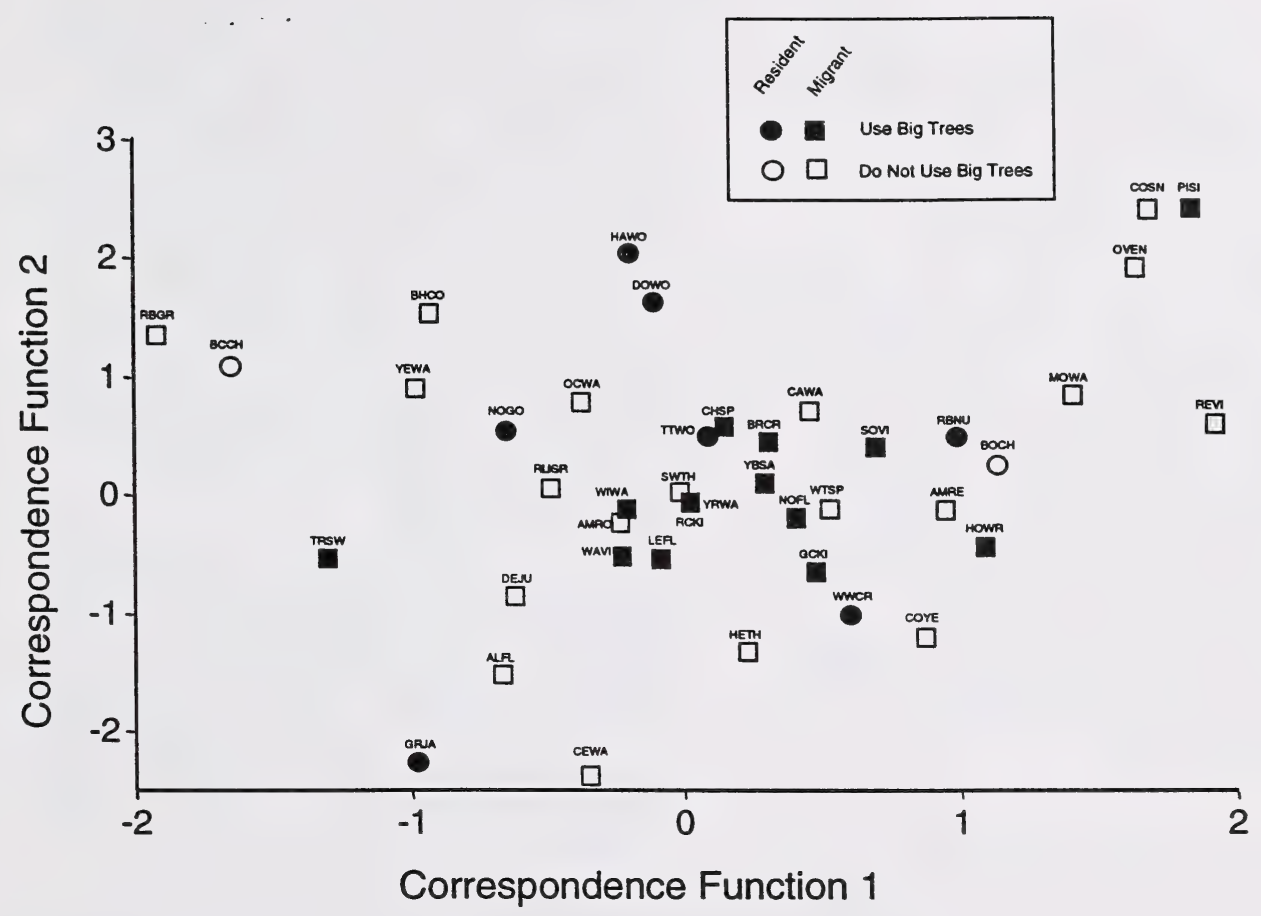

FIGURE 7.2. Predicted location for each bird species based on the correspondence analyses of bird densities in the Whitecourt study area during 1997. Species that are close together have strong positive covariance in abundance among sites whereas species that are far apart have strong negative covariance in abundance among sites. Species were categorized based on their migration and nesting/foraging habits. 
variation in vegetation characteristics among sites $(F=1.1, P=0.32)$.

\section{Grande Prairie Study Area}

Fifty species and 1592 individuals were detected during the bird surveys (Table 7.1). This bird community was dominated by species that migrate with only $18 \%$ of the species being year-round residents. Most residents $(67 \%$ of 9 species), but fewer migrants (34\% of 41 species) nested or foraged in large live or dead trees. Both species richness (Table 7.2) and number of individuals (Table 7.3) differed among stand groups. Differences in species richness were mainly due to differences for birds that did not use large trees and snags, whereas differences in abundance were due to differences for birds that did not use large trees and snags and differences for birds that migrate and use large trees. After adjusting for differences in richness and abundance among stand groups, richness and abundance were similar among treatments for all categories of birds.

When evaluating differences in bird communities among sites, the first and second functions of the CA had eigen values of 0.07 and 0.04 , respectively. Combined, these two functions accounted for only $4.1 \%$ of the variation in bird species density. However, even with this small amount of explained variation, bird communities were statistically different among stand groups (Fig. 7.3; $\mathrm{F}=1.9, \mathrm{P}<$ 0.01 ). After adjusting for differences among stand groups bird communities did not differ among treatments $(\mathrm{F}=1.2, \mathrm{P}=0.14)$. In addition, all categories of bird species were present in all stand groups (Fig. 7.4). Variation in the bird communities was not related to variation in vegetation characteristics among sites $(F=1.2, P=0.18)$.

\section{Discussion}

To achieve a rigorous experimental design, we chose two study areas that were large and relatively homogenous. Within these study areas, the stands (i.e., experimental harvest units) were similar to each other prior to harvest, but as expected within natural forests, the stands were not identical to each other. We created four groups of stands in each study area based on vegetation in and around the stands (see Chapter 2). This resulted in a study design where some of the variation in vegetation and structure could be accounted for statistically in a stratified analysis (Chapters 3 and 4). Similarly, within both study areas, variation among bird communities was related to differences among stand groups. That was true for both the simple analyses of bird species richness and abundance, and for the more complex community analyses.

However, variation among stand groups accounted for only a small amount of the variation in bird communities and the bird communities overlapped greatly among the stand groups. This was expected since there were only slight differences in vegetation among stand groups.

After controlling for the differences among stand groups, bird communities did not differ among treatments prior to harvest.

Consequently, if bird communities differ among treatments after harvest, those differences can be attributed unambiguously to differences in the size and dispersion of tree patches that were retained in these experimental areas during harvest. Thus, as planned, this study will provide a rigorous comparison of bird communities in among the three dispersions of standing trees and snags. The bird communities found in the stands prior to harvest are benchmarks from which I will evaluate differences after harvest.

\section{Future Research}

Bird communities will be surveyed during 1998 and 1999. However, most of the post-harvest bird surveys will be conducted during 1999 because birds may crowd into the remaining unharvested habitat immediately after harvest and those high densities probably will decrease during the next year (Lovejoy et al. 1986, Schmiegelow 1997). Bird surveys during 1999 will be an extended version of those conducted prior to harvest. Within each stand, the 10 ha (24.7 acres) study area (Figs. 2.1 and 2.2) will be surveyed using a combination of strip transects and point counts (see Methods). In addition, eight point counts will be centered in residual 


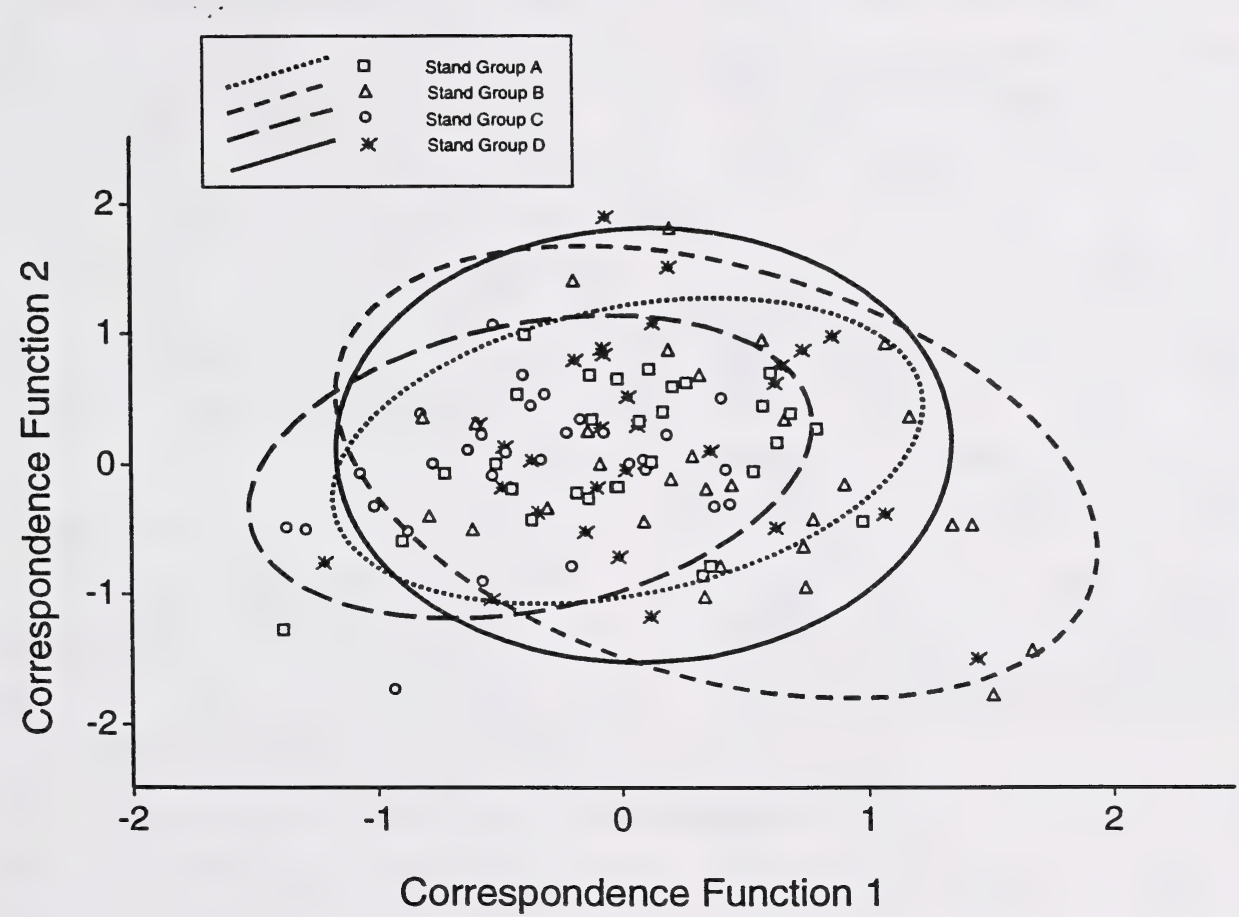

FIGURE 7.3. Correspondence analyses based on bird densities in the Grand Prairie study area during 1997. Sites that are close together within the correspondence plot have similar bird communities and sites that are far apart have dis-similar bird communities. Sites were categorized based on stand group. For each stand group bivariate ellipses that enclosed $90 \%$ of the sites were presented. 


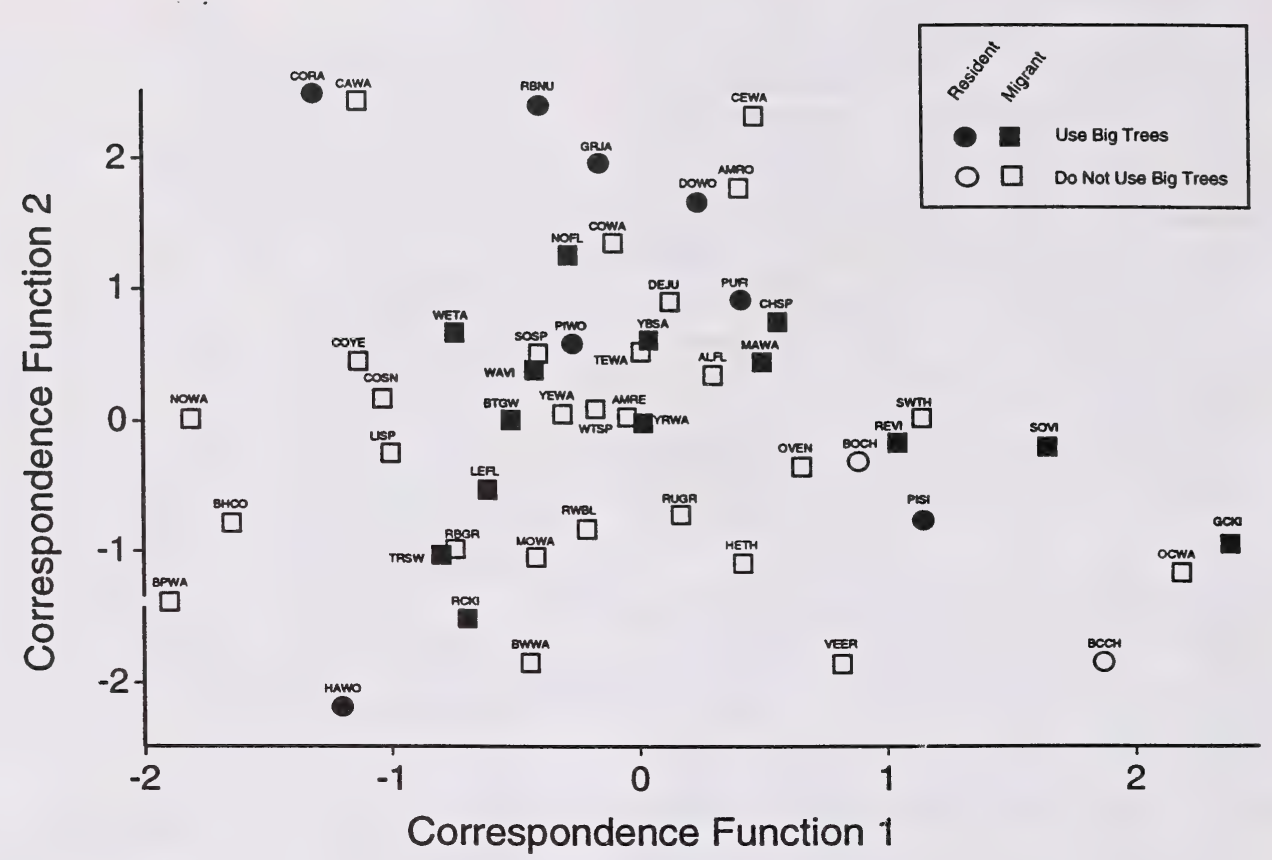

FIGURE 7.4. Predicted location for each bird species based on the correspondence analyses of bird densities in the Grande Prairie study area during 1997. Species that are close together have strong positive covariance in abundance among sites whereas species that are far apart have strong negative covariance in abundance among sites. Species were categorized based on their migration and nesting/foraging habits. 
clumps within each stand and four counts will be located $>100 \mathrm{~m}$ (>109 yd.) from residual clumps in each stand. Surveys will be conducted in all treatments once between 15 and 30 April, and three times at bi-weekly intervals between 15 May and 30 June. During the reduced 1998 survey, only 40 point counts will be conducted in each study area. Ten of these point counts will be centered within small residual patches, ten centered within mid-sized residual patches, ten centered within large residual patches, and ten $>100 \mathrm{~m}$ (>109 yd.) from residual patches. Results from these bird surveys will be analyzed and presented during fall and winters of 1998 and 1999.

\section{Literature cited}

Alberta-Pacific Forest Industries Inc. 1996. An operator's guide to stand structure. AlbertaPacific Forest Industries Inc., Boyle, AB.

British Columbia Ministry of Forests. 1995. Biodiversity guidebook, forest practices code of British Columbia. British Columbia Ministry of Forests, Victoria, BC.

Campbell, R.W., Dawe, N.K., McTaggartCowan, I., Cooper, J.M., Kaiser, G.W., and McNall, M.C. 1990. Birds of British Columbia. Volume II. Royal British Columbia Museum, Victoria, BC.

Eberhart, K.E., and Woodard, P.M. 1987. Distribution of residual vegetation associated with large fires in Alberta. Canadian Journal of Forest Research 17: 1207-1212.

Emlen, J. T., and M. J. DeJong. 1981. The application of song detection threshold distance to census operations. In Estimating numbers of terrestrial birds: proceedings of an international symposium held at Asilomar, California. Studies in avian biology No. 6: The American Ornithological Society. Edited by C. J. Ralph and M. Scott. Allen Press, Inc., Lawrence. pp. 346-352.

Gauthier, J., and Auby, Y. 1996. The breeding birds of Quebec. Canadian Wildlife Service, Montreal, QE.

Godfrey, W.E. 1986. The birds of Canada. National Museums of Canada. Ottawa, ON.
Hansen, A.J., Spies, T.A., Swanson, F.J., and Ohmann, J.L. 1991. Conserving biodiversity in managed forests. BioScience 41: 382-392.

Hobson, K.A., and Schieck, J. submitted. Changes in bird communities within boreal mixedwood forest during the first thirty years: contrasting the effects of harvest and wildfire. Ecological Applications.

Halvorsen, O.R. 1996. Are ordination and constrained ordination alternative or complementary strategies in general ecological studies? Journal of Vegetation Science 7: 289-292.

Hunter, M.L. 1993. Natural fire regimes as spatial models for managing boreal forests. Biological Conservation 65: 115-120.

Hutto, R.L. 1995. Composition of bird communities following stand-replacement fires in northern Rocky Mountain (USA) conifer forests. Conservation Biology 9: 10411058.

Lee, P.C., Crites, S., Nietfeld, M., Nguyen, H.V., and Stelfox, J.B. 1997. Characteristics and origin of deadwood material in aspendominated boreal forests. Ecological Applications 7: 691-701.

Lovejoy, T.E., Bierregaard, R.O., Rylands, A.B., Malcolm, R.J., Quintela, C.E., Harper, L.H., Brown, J.R., Powell, A.H., Powell, G.V., Schubart, H.O., and Hays, M.B. 1986. Edge and other effects of isolation on Amazon forest fragments. In Conservation biology: the science of scarcity and diversity. Edited by M.E. Soule, Sinuaer Associates, Sunderland, Mass. pp. 257-285.

MacKenzie, K., and Steventon, D. 1996. Bird use in a patch retention treatment in SBSmc forests. British Columbia Ministry of Forests, Prince Rupert Forest Region, Extension Note 16.

Norton, M.R., and Hannon, S.J. 1997. Songbird response to partial-cut logging in the boreal mixedwood forest of Alberta. Canadian J. Forest Resources 27: 44-53.

Porneluzi, P., Bednarz, J.C., Goodrich, L.J., Zawada, N., and Hoover, J. 1993.

Reproductive performance of territorial 
ovenbirds occupying forest fragments and a contiguous forest in Pennsylvania.

Conservation Biology 7: 618-622.

SAS Institute Inc. 1989. SAS/STAT User's Guide, Version 6, Fourth Edition, Volume 1 And 2. SAS Institute Inc., Cary, N. C.

Saunders, D.A., Hobbs, R.J., and Margules, C.R. 1991. Biological consequences of ecosystem fragmentation: a review. Conservation Biology 5: 18-32.

Schieck, J. 1997. Biased detection of bird vocalizations affects comparisons of bird abundance among forested habitats. Condor 99: 179-190.

Schieck, J., Nietfeld, M., and Stelfox, J.B. 1995. Differences in bird species richness and abundance among three successional stages of aspen dominated boreal forests. Canadian Journal of Zoology 73: 1417-1431.

Semenchuk, G.P. 1992. The atlas of breeding birds of Alberta. Federation of Alberta Naturalists, Edmonton, AB.

Schmiegelow, F.K., Machtans, C.S., and Hannon, S.J. 1997. Are boreal birds resilient to forest fragmentation? An experimental study of short-term community responses. Ecology 78: 1914-1932.
Seip, D., and Parker, K. 1997. Use of wildlife tree patches by forest birds in the Sub-Boreal Spruce (SBS) zone. British Columbia Ministry of Forests, Prince George Forest Region, Note PG-08.

Spies, T.A., Tappeiner, J., Pojar, J., and Coates, D. 1991. Trends in ecosystem management at the stand level. In Transactions of the fiftysixth North American wildlife natural resources conference. Edited by R.E. McCabe, Wildlife Management Institute, Washington DC. pp. 628-639.

Systat Inc. 1989. SYGRAPH graphics. Evanston, IL.

ter Braak, C.J. 1992. CANOCO - A FORTRAN program for canonical community ordination. Microcomputer Power, Ithaca, New York.

Urban, D.L., O'Neill, R.V., and Shugart, H.H. 1987. A hierarchical perspective can help scientists understand spatial patterns. Landscape Ecology 37: 119-127.

Wolf, A.T., Howe, R.W., and Davis, G.J. 1995. Detectability of forest birds from stationary points in northern Wisconsin. In Monitoring bird populations by point counts. Edited by C.J. Ralph, J.R. Sauer, and S. Droege, USDA Forest Service, General Technical Report PSW-GTR-149, Albany, CA. pp. 19-23. 


\section{CHAPTER 8. THE USE OF RESIDUAL PATCHES BY BATS IN THE BOREAL FOREST OF NORTHWESTERN ALBERTA}

\section{Lui Marinelli}

\section{Introduction}

Timber harvesting strategies are restructuring the boreal forest mosaic in Alberta. With the recent introduction of aspen into harvesting plans, forests are being reshaped at an even faster rate. Holling (1995) characterized traditional resource management as controlling the variability of ecosystems so that a steady flow of goods and services could be produced for humans. This traditional view of forest value is limited to the monetary worth of present and future timber resources. Emerging environmental, ecological, and social concerns are forcing a much broader perspective of resource-use strategies. Strategies of ecosystem management are being developed (e.g., Alberta Forest Conservation Strategy 1997), encouraging private companies to reassess the value of the forest and modify traditional harvesting practices (e.g., Alberta Pacific Forest Industries Inc. 1996).

Harvesting practices are evolving to include leaving standing trees and snags in harvested areas in an effort to retain pre-harvest species of flora and fauna. Such forest structure may make harvested areas more desirable to native bats that use the forest environment to forage, roost, and breed (Thomas 1988). Currently, the pattern in which residual trees and snags are left on the landscape is decided subjectively (Alberta Pacific Forest Industries Inc. 1996). Objective decision-making requires a greater understanding of the effect on biotic communities of retaining residual elements and the manner of their dispersion.

The boreal forest of Alberta supports five species of bats (van Zyll de Jong 1983). These bats show a fair degree of fidelity to roost sites in the forest when they return from hibernaculum or migration. During the spring and summer, cavity-roosting colonial species use a wide variety of cavities including spaces behind exfoliated bark and natural or excavated cavities in large, old snags (Thomas and La Val 1988). Within Douglas-fir forests of southern Washington State, old forests were considered critical for bats because they contained large, decayed snags, which provide crevices for cavity-roosting bat species (Thomas 1988). The two foliage-roosting solitary species (Lasiurus cinereus and Lasionycteris noctivagans) generally do not exploit cavities but roost in fixed or shifting locations in foliage of large, live trees (Barclay 1984). In some species, males and females use different habitats (Barclay 1991). Males do not maintain high body temperatures during the day and may select cool roosts to minimize their metabolic rates and diurnal energy expenditures (Thomas 1988). Females have a reproductive constraint on their ability to exploit the energy saving of torpor because fetal growth rates and presumably milk production are temperaturedependent processes (Racey 1982). During pregnancy and lactation, females maintain body temperatures well above ambient during the day to maximize fetal growth rates (Kunz 1982b, Racey 1982) and as such tend to select warm roost sites. Thus, retaining bats in forest patches will depend upon requirements of different bat species and sexes.

In this study, three treatments with different clump size and distances between clumps in two experimentally harvested areas will be established to evaluate how bat communities respond to harvested forests. We will concentrate on differences that are detected in the first two years following harvest, however, throughout the forest rotation the opportunity exists to evaluate the value to bats of the patches that are created in the experiment.

\section{Objectives}

I will compare bat communities among three different harvesting treatments (Chapter 2) to evaluate which pattern of dispersion of residual 
trees maximizes bat diversity and abundance.

Pre-harvest sampling will be used to assess whether bat communities were similar among treatments prior to harvest: Post-harvesting bat communities will be compared among the three treatments using data that will be collected during 1998 and 1999.

\section{Methods}

A description of the study areas and experimental harvesting is presented in the Study Area and Methods section (Chapter 2). Descriptions of the pre-harvest trees, snags, downed woody materials, and understory vegetation are presented in Chapters 3 - 5 .

Bat detectors were used to estimate species richness and abundance in each stand in both Whitecourt and Grande Prairie study areas in July and August 1997. Ultrasonic detectors do not provide data that can be translated directly into estimates of population density (Thomas and La Val 1988); they do however, provide a relatively unbiased index of the levels of use or animal abundance among habitats (Thomas 1988). Detectors consisted of an Anabat IV ultrasonic bat detector (Titley Electronics, AUS), a delay switch, a cassette recorder, and a 12-volt battery, all of which were housed in a 1.5 litre (1.6 gal.) rubbermaid container. A $2 \mathrm{~cm}$ ( $0.8 \mathrm{in}$.) hole was cut into the side of the container to accommodate the microphone. The battery was used to run the detector and the delay switch. The delay switch was set to turn the detector on at dusk and off at dawn. The sensitivity setting on the detectors was set between 6 and 7 to minimize insect noise and to eliminate detection of bats flying in adjacent stand groups. To allow the bat call to be recorded by a cassette recorder, the frequency of each call was reduced from the ultrasonic to the audible range by setting the division ratio on detectors to 16 .

Bats were surveyed from three points, approximately $300 \mathrm{~m}$ (328 yd.) apart, in each stand. Two stands in each study area were sampled simultaneously. Detectors were attached to trees $1.5 \mathrm{~m}$ ( $5 \mathrm{ft}$.) off the ground and oriented such that the microphone was pointing 45-degree above horizontal. Detectors were run for three consecutive nights in each stand and were checked each morning to ensure proper functioning. After three days, detectors were moved to new stands.

Bats were identified by analyzing their searchphase echolocation calls. Each sequence of one or more echolocation pulses with $<1 \mathrm{~s}$ between sequential pulses was recorded as a pass by a bat (Fenton 1970). Calls were analyzed using Anabat and Analook software (Titley Electronics, AUS). Frequency range and call shape from the calls we recorded were compared with a library of calls from known species.

Differences in bat abundance were evaluated among stand groups and treatments using oneway ANOVAs. In all analyses, results were considered statistically significant if the probability of them occurring by chance was less than 0.05 . Canonical correlation analysis was used to evaluate the relationship between the bat abundance and characteristics of trees in each stand. In both areas, I included the following tree variables in the analyses: density of snags with a diameter at breast height (DBH) of $<20 \mathrm{~cm}$ ( $<7.9 \mathrm{in}$.), snags $>20 \mathrm{~cm}$ ( $>7.9 \mathrm{in}$.) $\mathrm{DBH}$, and total volume of down woody material. In the Whitecourt study area, density of pine and black spruce $<20 \mathrm{~cm}$ ( $<7.9 \mathrm{in}$.) $\mathrm{DBH}$ and density of pine and black spruce $>20 \mathrm{~cm}$ (>7.9 in.) $\mathrm{DBH}$ were included in the analyses. In the Grande Prairie study area, density of aspen and white spruce $<20 \mathrm{~cm}$ ( $<7.9$ in.) DBH and density of aspen and white spruce $>20 \mathrm{~cm}$ (>7.9 in.) DBH were included in the analyses.

\section{Results}

Based on 756 hrs of data collection in each area almost twice as many bat calls were detected in the Grande Prairie study area $(n=120)$ as in the Whitecourt study area $(n=67)$. Of the bats detected $(n=187)$, the majority were identified as little brown bats (Myotis lucifugus). Hoary bats (Lasiurus cinereus) were detected three times in the Whitecourt study area. Accordingly, I restricted the analyses to detections of the little brown bats. 
TABLE 8.1. Mean ( \pm SE) number of little brown bat calls detected within each stand group and treatment in Whitecourt and Grande Prairie study areas.

\begin{tabular}{llll}
\hline & & Whitecourt & Grande Prairie \\
\hline \multirow{3}{*}{ Stand group } & 1 & $2.3(1.5)$ & \\
& 2 & $2.7(1.5)$ & $7.0(4.4)$ \\
& 3 & $2.7(1.2)$ & $1.7(0.7)$ \\
Treatment & 4 & $8.0(6.5)$ & $2.3(1.2)$ \\
& 1 & $1.8(1.1)$ & \\
& 2 & $2.3(1.0)$ & $6.0(2.3)$ \\
& 3 & $7.8(4.5)$ & $5.5(2.2)$ \\
\hline
\end{tabular}


Bat detections in the Whitecourt study area did not differ among treatments $\left(\mathrm{F}_{2.11}=1.50, \mathrm{P}=\right.$ 0.27 ) or among stand groups $\left(\mathrm{F}_{3,11}=0.62, \mathrm{P}=\right.$ 0.62; Table 8.1). In the Grande Prairie study area no significant difference was detected among treatments $\left(\mathrm{F}_{2.11}=0.09, \mathrm{P}=0.92\right)$. However, among stand groups, some differences were significant $\left(\mathrm{F}_{3,11}=5.23, \mathrm{P}=\right.$ 0.03). A Tukey post-hoc test suggested that difference between stand group 1 and stand groups 3 and 4 are responsible for the significant difference.

The density of trees and snags accounted for only a small amount of the variation in the bat numbers in both study areas (4\% in Grande Prairie, and 5\% in Whitecourt). In the Grande Prairie study area, aspen density [both $<$ and $>$ $20 \mathrm{~cm}$ (7.9 in.) DBH] was the best predictor of bat abundance (Fig. 8.1). Snag density [ $>20 \mathrm{~cm}$ (>7.9 in.) $\mathrm{DBH}$ ] was the best predictor of bat abundance in the Whitecourt study area and was positively correlated with bat abundance (Fig. 8.2). The graphical depiction of the relationship between bat abundance and tree variables (Fig. 8.1 and 8.2) also shows the lack of differentiation among the stand groups and treatments in both study areas.

\section{Discussion}

Stands in each area were categorized into four stand groups based on observed similarity in vegetation in and around the stands (see Chapter 2). Little brown bats were equally abundant in all stand groups in the Whitecourt area, but were more abundant in stand group 1 in the Grande Prairie area. Accordingly, if the density of little brown bats in the Whitecourt area differs among stands after harvest, those differences can be attributed to differences in the size and dispersion of tree patches that were retained at harvest. However, in the Grande Prairie study area, post-harvest differences will have to be evaluated after taking into account pre-harvest differences.

Aspen trees in the Grande Prairie study area and snags in the Whitecourt study area appeared to be important in predicting bat abundance. Bats rely on crevices in trees or raised bark to roost during the day. Accordingly, snags in the
Whitecourt study area may be important because of the roost sites they offer. Bats can also roost in live trees, using naturally occurring cracks or excavated cavities. Bats may also select an area based on the dispersion of live trees. Although bats do not appear to spend a significant portion of their time feeding in the forest (Thomas 1988), when they do, they require a corridor to fly and feed. Mature aspen in the Grande Prairie study area may provide roost sites and/or the proper corridors for feeding.

\section{Future Research}

Bat communities will be surveyed during 1998 and 1999 to evaluate the effect of the harvest treatments on bats. Three bat detectors units will be positioned in a stand each night; one at the center of a residual patch, one at the patch edge, and one within the clear-cut area. Bat calls will be recorded for three consecutive nights. Flying insect communities will be sampled concurrently at these same locations using insect intercept traps that will be suspended at a height of $2 \mathrm{~m}(6.6 \mathrm{ft}$.). Insect collection will be limited to the time when bats are most active, from sunset to three hours after sunset, by using automated traps that will be controlled by photocells, timers, and motors. Results from bat surveys will be analyzed and presented during fall and winters of 1998 and 1999.

\section{Literature cited}

Alberta Forest Conservation Strategy Steering Committee. 1997. Alberta Forest Conservation Strategy. A New Perspective on Sustaining Alberta's Forests. Alberta Lands and Forest Service, Alberta Environmental Protection, Edmonton, Alberta.

Alberta-Pacific Forest Industries Inc. 1996. An operator's guide to stand structure. AlbertaPacific Forest Industries Inc., Boyle, AB

Barclay, R.M.R. 1991. Population structure of temperate zone insectivorous bats in relation to foraging behaviour and energy demand. $\mathbf{J}$. Anim. Ecology 60: 165-178. 


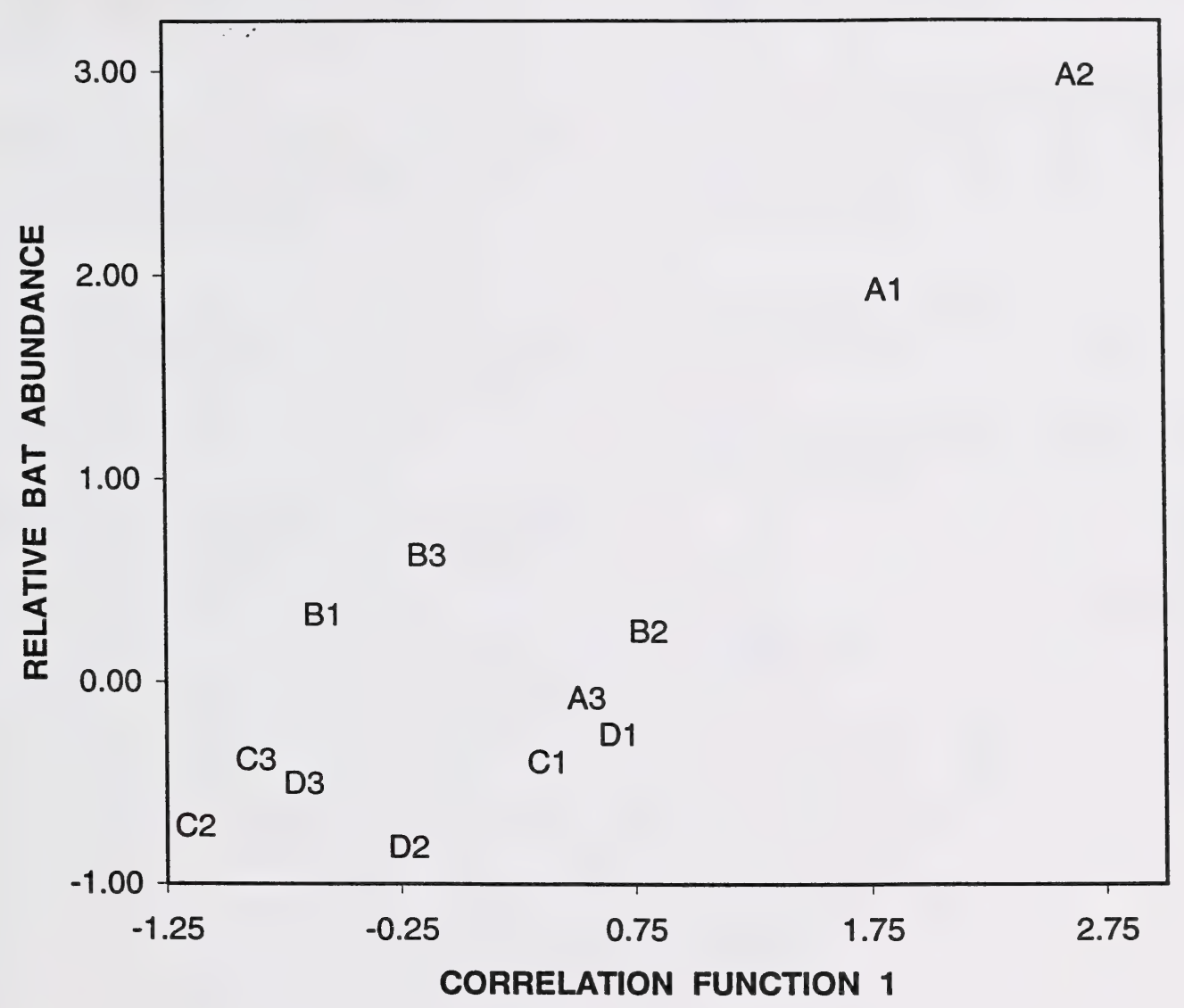

FIGURE 8.1. Canonical correlation analyses based on abundance of little brown bats in boreal forest stands near Grandè Prairie, AB during 1997. The first correlation function describes an increasing density of aspen trees. The symbols represent each stand identified by stand group (A-D) and treatment (1-3). 


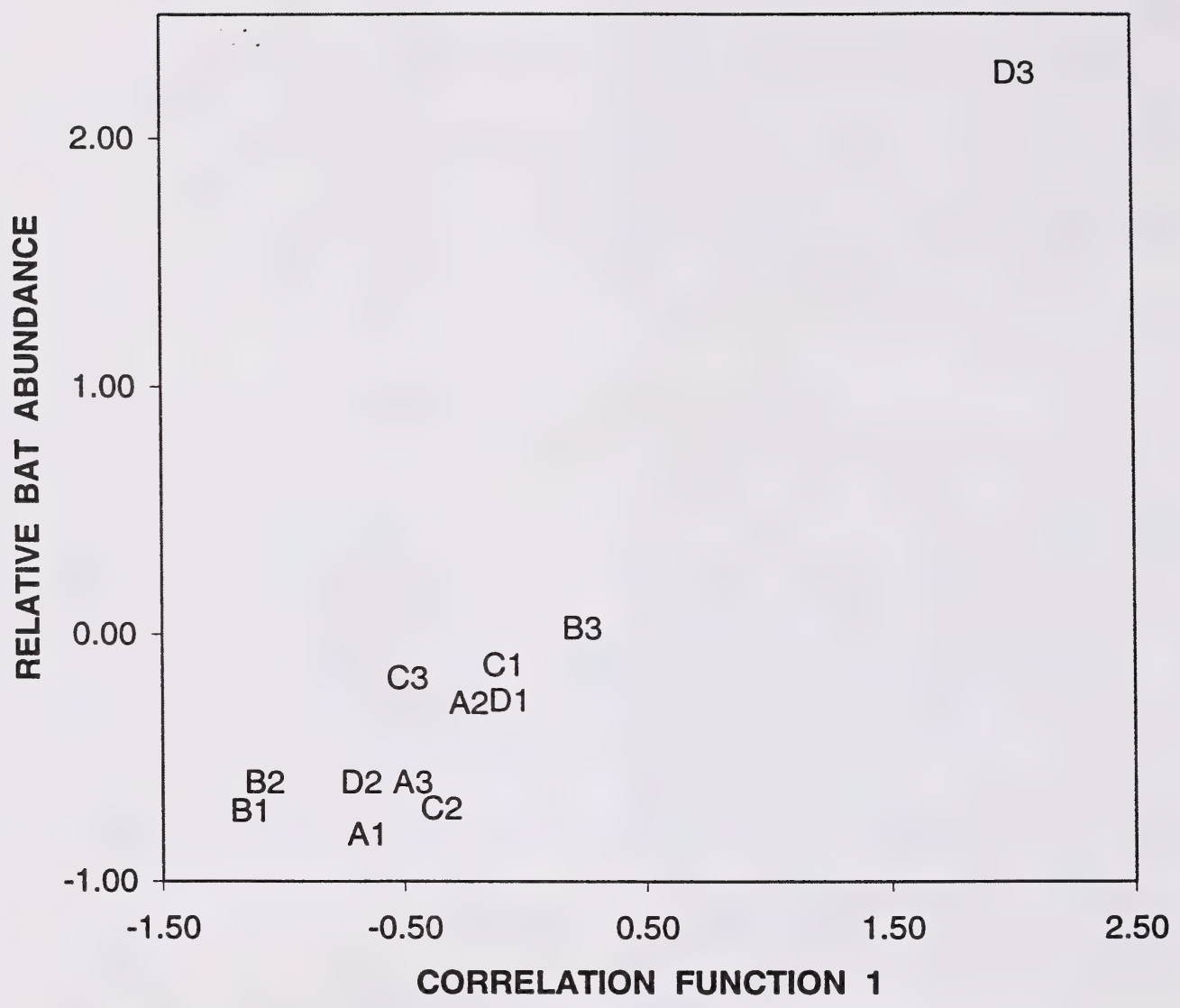

FIGURE 8.2. Canonical correlation analyses based on abundance of little brown bats in boreal forest stands near Whitecourt, $\mathrm{AB}$ during 1997. The first correlation function describes an increasing density of snags with a DBH of $>20 \mathrm{~cm}(>7.9 \mathrm{in}$.). The symbols represent each stand identified by stand group (A-D) and treatment (1-3). 
Barclay, R.M.R. 1984. Observations on the migration and behaviour of bats at Delta Marsh, Manitoba. Can. Field-Nat. 98: 331336.

Fenton, M.B. 1970. A technique for monitoring bat activity with results obtained from different environments in southern Ontario. Can. J. Zool. 48: 847-851.

Holling, C.S. 1995. What barriers? What bridges? In Barriers and bridges to the renewal of ecosystems and institutions. Edited by Gunderson, L.H., Holling, C.S., and Light S.S., Columbia University Press, New York. pp. 3-34.

Kunz, T.H. 1982. Roosting ecology. In Ecology of Bats. Edited by T.H. Kunz. Plenum Press, New York. pp. 1-55.
Thomas, D.W. 1988 . The distribution of bats in different ages of Douglas-fir forests. J. Wildl. Manage. 52: 619-626.

Thomas, D.W. and R.K. La Val. 1988. Survey and Census Methods. In Ecological and Behavioral Methods for the Study of Bats. Edited by T.H. Kunz. Smithsonian Institute Press, Washington, D.C. pp 77-89.

Racey, P.A. 1982. Ecology of bat reproduction. In Ecology of Bats. Edited by T.H. Kunz. Plenum Press, New York. pp. 57-104.

Van Zyll de Jong, C.G. 1985. Handbook of Canadian Mammals: Bats. Natural Museums of Canada, Ottawa. 
•

$\therefore$ 

